Universidad de Lima

Facultad de Derecho

Carrera de Derecho

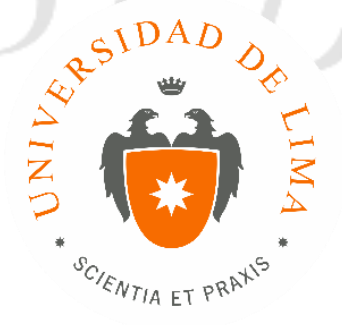

\title{
ANÁLISIS ECONÓMICO DEL DERECHO DE \\ LOS CONTRATOS DE MATERNIDAD SUBROGADA EN EL PERÚ
}

Trabajo de investigación para optar el Título Profesional de Abogado

Jalil Musbaj Percy, Mardini Burgos

Código 20120787

Asesor

Jairo Cieza Mora

Lima - Perú

junio de 2018 


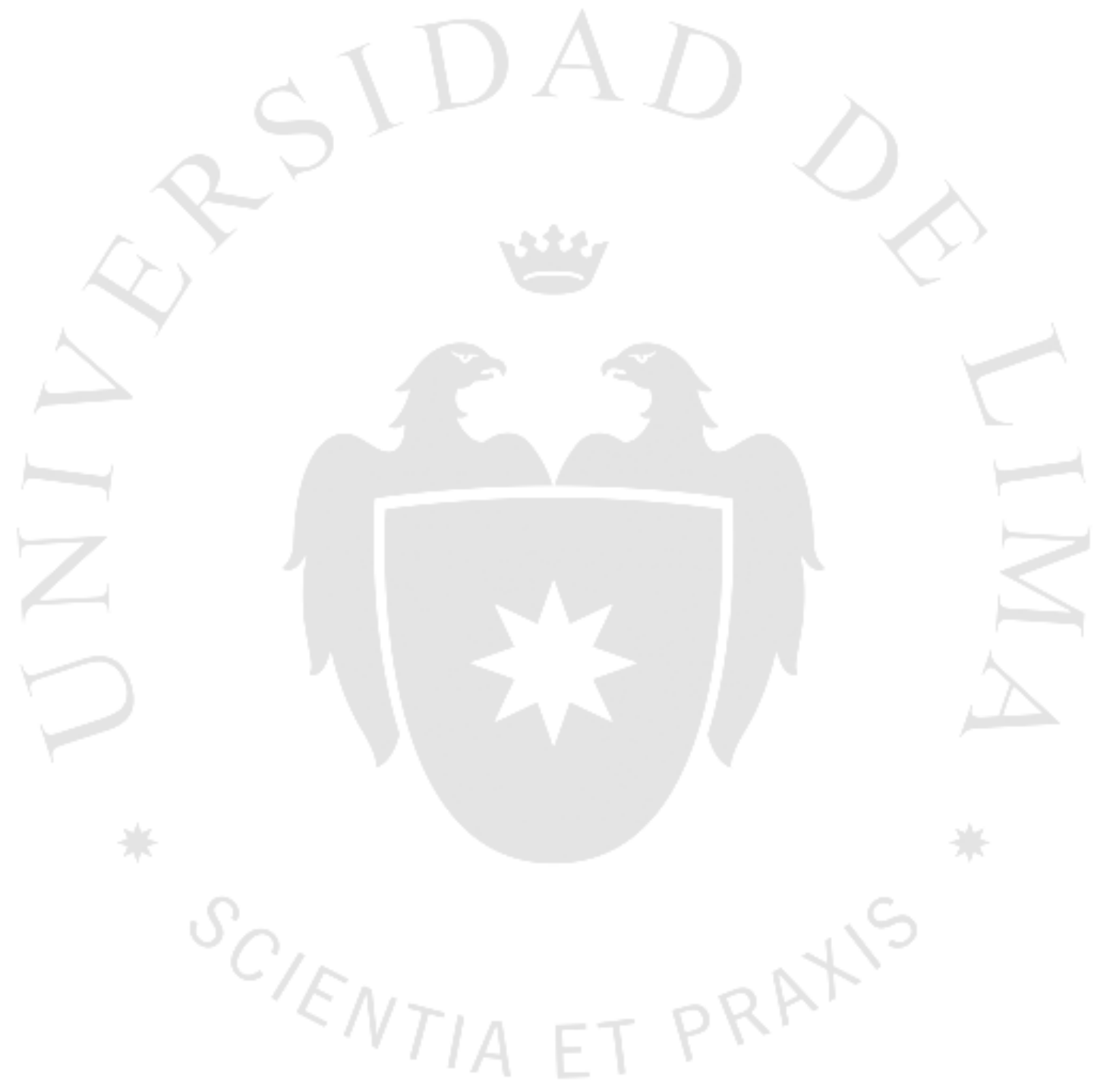


ANÁLISIS ECONÓMICO DEL DERECHO DE LOS CONTRATOS DE MATERNIDAD SUBROGADA EN EL PERÚ 


\section{TABLA DE CONTENIDO}

Tabla de contenido

INTRODUCCIÓN.

CAPÍTULO I: EVOLUCIÓN DE LA BIOÉTICA TRADICIONAL Y ANÁLISIS ECONÓMICO DEL DERECHO APLICABLE A LA MATERNIDAD SUBROGADA..........................................................................

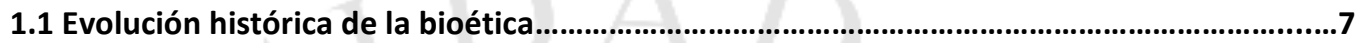

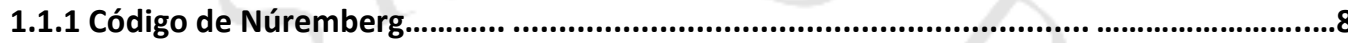

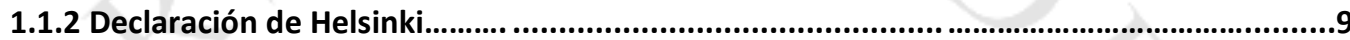

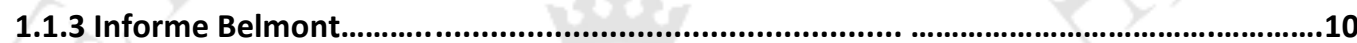

1.1.4 Declaración Universal sobre Bioética y Derechos Humanos de la UNESCO.......................13

1.2 Principios de la Bioética aplicables a la maternidad subrogada.........................................16

1.2.1 El principio del respeto a las personas en la maternidad subrogada.................................16

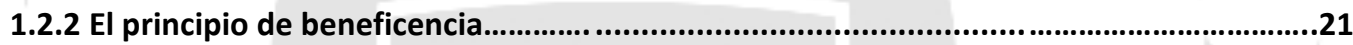

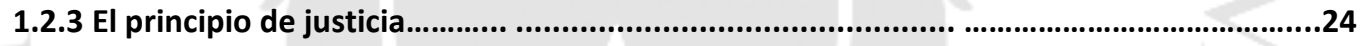

1.3 Análisis Económico del Derecho aplicado a la maternidad subrogada..............................27

1.3.1 Críticas al Análisis Económico del Derecho aplicable a la maternidad subrogada...........28

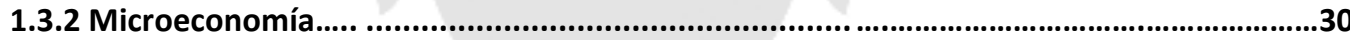

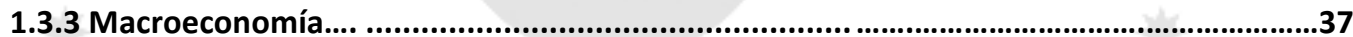

CAPÍTULO II: ANÁLISIS ECONÓMICO DE LEGISLACIÓN COMPARADA EN LA MATERNIDAD

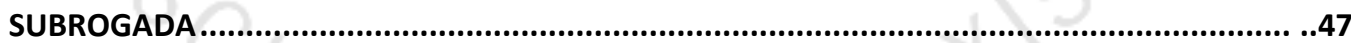

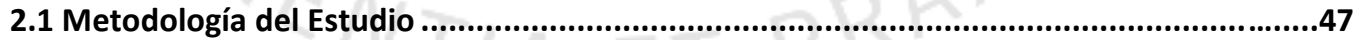

2.2Análisis económico y legal de la maternidad subrogada en el estado de California (Estados Unidos).

2.2.1 Análisis del marco legal en el estado de California ......................................................49

2.2.2 Análisis del mercado e impacto en el estado de California ........................................53

2.3 Análisis económico y legal de la maternidad subrogada en la India 
2.3.1 Análisis del marco legal en la India.

2.3.2 Análisis del mercado e impacto en la India.

2.4 Análisis económico y legal de la maternidad subrogada en el Reino Unido. .63

2.4.1 Análisis del marco legal en el Reino Unido

2.4.2 Análisis del mercado e impacto en el Reino Unido . .65

2.5.Análisis económico y legal de la maternidad subrogada en España...................................68

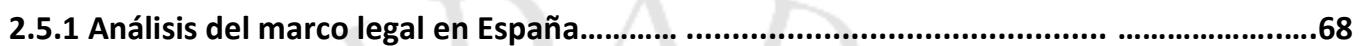

2.5.2 Análisis del mercado e impacto en España...............................................................71

2.6 Análisis económico y legal de la maternidad subrogada en Argentina .............................73

2.6.1 Análisis del marco legal en Argentina.................................................................73

2.6.2 Análisis del mercado e impacto en Argentina.................................................................75

CAPÍTULO III: ANÁLISIS ECONÓMICO APLICABLE A UN MARCO LEGAL DE LA MATERNIDAD

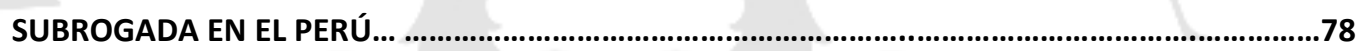

3.1 Análisis económico legal de la maternidad subrogada en el Perú.......................................78

3.1.1 Análisis del marco legal en Perú .................................................................................79

3.1.2 Análisis del mercado e impacto en Perú..........................................................................83

3.1.3 Propuestas para un marco legal de la maternidad subrogada en el Perú.........................87

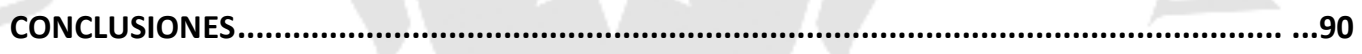

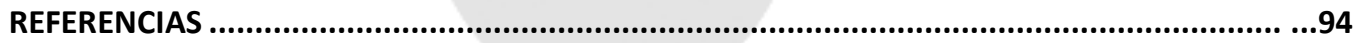

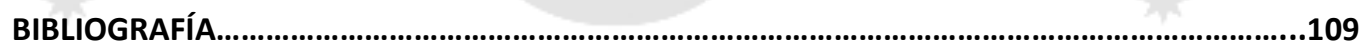

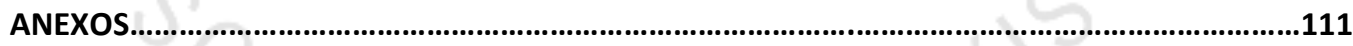

6.1ANEXO 1: Análisis de regresión entre oportunidad económica de la mujer y precio de compensaciones de madres gestantes 


\section{ÍNDICE DE FIGURAS}

Figuras1-1 "Diagrama del efecto del control de precios tope sobre la curva de oferta y la demanda" .38

Figuras.1-2 "Diagrama del efecto de control de precios base sobre la curva de oferta y demanda" .44

Figuras.1-3 “Mapa de correlación y tendencias entre la Oportunidad Económica de la Mujer y Precio de compensación... . .46 


\section{ÍNDICE DE ANEXOS}

ANEXO 1: Análisis de regresión entre oportunidad económica de la mujer y precio de compensaciones de madres gestantes. 


\section{INTRODUCCIÓN}

"La maternidad subrogada" o "vientre de alquiler" no presenta uniformidad a nivel global en relación a sus regulaciones. Por ejemplo, encontramos que en algunos estados de los Estados Unidos como California (Johnson vs Calvert, 1993) España (Ley 35-1998) y la India (Ley 57-1994) las legislaciones permiten a las madres gestantes recibir una contraprestación por brindar el servicio de subrogación, pero también encontramos que en países como Alemania (Ley 745-90) o Francia (Ley 2004-800) dichos contratos se consideran nulos. Incluso encontramos países como Reino Unido (Surrogacy Arrangement Act 1985, 1985) donde solo se permite realizar estos convenios de forma altruista (es decir, sin ánimo de lucro, aunque permitiendo una compensación a la madre gestante) y finalmente países como China donde se opta por la desregulación y omisión legislativa.

En nuestro país la prohibición se encuentra establecida en el artículo 7 de la Ley General de Salud, limitando las técnicas de reproducción asistida a que la condición que la madre gestante y la madre biológica sean la misma persona. Las carencias de dicha regulación se vieron evidenciadas tanto hace 10 años con la Casación 563-2011-LIMA, como el 21 de febrero del 2017 con una reciente sentencia del Tribunal Constitucional de expediente $\mathrm{N} .^{\circ}$ 00147-2017-Q/TC donde se le ordena a la RENIEC reconocer como madre a una pareja que alquilo el vientre y otorgando legitimidad a un acto expresamente contrario a la ley. Ante la nueva realidad, contamos con dos sentencias una de la Corte Suprema y otra del Tribunal Constitucional que reconocen relaciones contrarias a la norma. ¿Será necesario seguir nuevos lineamientos?

El presente trabajo buscará a ahondar en los argumentos que el análisis económico del Derecho puede darnos al respecto, siguiendo una perspectiva de Derecho comparado y analizando los efectos sociales y económicos en estos con la finalidad de proponer directrices respecto a una nueva legislación en materia de maternidad subrogada que se desenvuelva de forma eficiente en el país. 
La presente tesis es una investigación de carácter bibliográfica que tiene por objetivo evaluar a través de la perspectiva del análisis económico del Derecho la legislación peruana actual en materia de maternidad subrogada, comúnmente conocida como "vientre de alquiler". A pesar que la mayor parte de la investigación será documental, también presentará algunos elementos de la investigación de campo como la obtención de información directa con agentes del mercado de maternidad subrogada a través de correo electrónico y observación del comportamiento de dichos agentes en los medios electrónicos donde se contactan para realizar las transacciones, a modo que puedan darnos una opinión más cercana respecto a la realidad de la industria de vientre de alquiler.

El trabajo presenta los siguientes capítulos:

En el capítulo I se presenta un breve análisis histórico de la evolución de la bioética con el objetivo de explicar el origen de los principios bioéticos descritos en el Informe Belmont. A través de dichos principios, se realizará un análisis de su aplicación en la realidad de la maternidad subrogada. Posteriormente dichos principios serán observados en su aplicación con un análisis utilitario a la bioética y los beneficios que nos otorga dicho modelo analítico. Finalmente, se procederá con una breve definición de lo que es el Análisis económico del derecho, sus orígenes y principales críticas para posteriormente revisar qué es lo que nos dice dicha escuela sobre la maternidad subrogada.

En el capítulo II, se realizará el análisis económico de la maternidad subrogada apoyándose en la disciplina del derecho comparado. La estructura del análisis por país iniciará por la descripción del marco legal del país objetivo, luego se proseguirá con la descripción de la industria en determinado país para el cual se usará el modelo de análisis de "5 Fuerzas de Porter" modificado (modelo de análisis de industrias y mercados) y posteriormente el impacto económico-social de dicha legislación.

Los países que serán objeto de análisis serán: Estados Unidos, India, Reino Unido, España y Argentina. Los mismos fueron elegidos bajo criterio de contar con legislaciones y realidades sociales diametralmente distintas entre sí, por lo que nos permitirán observar más variables que influyan en el mercado, así como sus distintos efectos. 
En el capítulo III, usaremos la estructura del análisis descrita anteriormente para describir el marco legal, la industria y sus consecuencias económicas y sociales en la realidad peruana. Adicionalmente, se brindará propuestas para un nuevo marco legal de la maternidad subrogada en el Perú.

La presente tesis contempla el siguiente objetivo superior: Proponer directrices para un marco legal eficiente en materia de contratación de la maternidad subrogada en el Perú, en consideración de su situación social y económica.

Para alcanzar dicho objetivo, es necesario cumplir con los siguientes objetivos específicos:

(1) Entender cómo funciona el comportamiento económico entre los agentes de dicho mercado.

(2) Analizar el impacto económico y social del marco legal de la maternidad subrogada en los siguientes países; Estados Unidos, La India, y Reino Unido, España y Argentina, puesto que más allá de las teorías que la escuela económica puedan plantear, es necesario contrastarlas con el impacto de la realidad.

(3) Analizar a través de un enfoque económico y social el marco legal actual de la maternidad subrogada en el país, pues, basándonos en el presupuesto que las leyes deben ser adaptadas a la realidad de cada país, es necesario revisar su situación antes de proponer directrices legales.

Asimismo, a efecto de otorgar el marco teórico necesario para la lectura de la tesis, es necesario entender que el análisis económico será necesario definir tanto conceptos de orden jurídico como económico.

Primero, resulta esencial definir el concepto legal de "maternidad subrogada", para el cual me basaré en los siguientes juristas:

Ronaldo Peralta Andia define la maternidad subrogada como "el convenio por el cual una mujer se compromete frente a otra u otras a gestar en su vientre un embrión fecundado extracorpóreamente, ya en forma homóloga o heteróloga, para luego entregar la criatura después del parto.” (Peralta Andia, 2004, p. 187) 
Juan Espinoza Espinoza afirma que "la madre sustituta es aquella mujer que ofrece su útero para que se desarrolle en éste el embrión concebido extracorpóreamente, para después entregar el bebé a sus verdaderos padres." (Espinoza Espinoza, 2004, p. 121)

Del mismo modo, utilizaremos la definición de "consentimiento informado" otorgada por el Comité de expertos de la Organización Mundial de la Salud, el cual define el consentimiento informado como la:

“(...) Confirmación voluntaria por parte del sujeto de su deseo de participar en un determinado ensayo clínico, y documentación de la misma. Este consentimiento se debe solicitar sólo después de que se ha proporcionado toda la información apropiada sobre el ensayo, incluyendo una explicación de su condición de investigación, sus objetivos, sus posibles beneficios, riesgos e incomodidades, otros tratamientos que puedan existir, y los derechos y las responsabilidades del sujeto (...)” (Organización Mundial de la Salud, 1993, párr.6).

Con respecto al concepto de interés superior del niño, usaremos la definición otorgada en el artículo 2 la Ley N 30466, el cual define el mismo como: "el interés superior del niño es un derecho, un principio y una norma de procedimiento que otorga al niño el derecho a que se considere de manera primordial su interés superior en todas las medidas que afecten directa o indirectamente a los niños y adolescentes, garantizando sus derechos humanos." (Ley N 30466, 2016).

Adicionalmente, dentro de los conceptos de economía usados en la investigación, entendemos que el Óptimo de Pareto se refiere a "que cualquier cambio de situación afectaría a una economía sin perjudicar a otra. Es decir, las situaciones son eficientes, si al haber un cambio de esa situación, se beneficia alguno sin perjudicar a otros." (Miller \& Meiners, 1989) Citados por (Otilio Reyes \& Franklin Sam, 2014, pág. 223)

Entre las principales hipótesis a sustentar en la presente investigación encontramos:

1. La labor del estado en la maternidad subrogada debe limitarse a fortalecer la institucionalidad y seguridad jurídica, pues de esa forma se permite un eficiente intercambio de recursos. 
2. El control de precios y las medidas restrictivas de la maternidad subrogada dañan a los agentes de dicho mercado.

3. Las agencias de subrogación son beneficiosas para ambos lados en el mercado de maternidad subrogada y la apariencia de esclavitud es producto de una mirada occidental sesgada. No generan ineficiencia pues brindan un servicio valorado por los agentes y buscan suplir las deficiencias propias de la industria.

4. Control de precios de la maternidad subrogada es perjudicial y es ineficaz pues crea informalidad en dicha actividad.

5. El arrepentimiento en los contratos de maternidad subrogada crea inseguridad jurídica $\mathrm{y}$, por ende, afecta al mercado de forma similar a la desregulación, desincentivando la actividad y restándole poder negocial a la madre gestante.

Finalmente, el periodo de indagación se limitará a fuentes de investigadores que no superen los treinta y cinco años de antigüedad tales como como Richard Posner (1989), Hatzis Arístides (2003), Alfredo Bullard (2009). Stephen G. York (1991) en conjunto con documentación periodística y de internet que nos permitan acceder a los datos más actualizados de la situación social y económica de cada país investigado. 


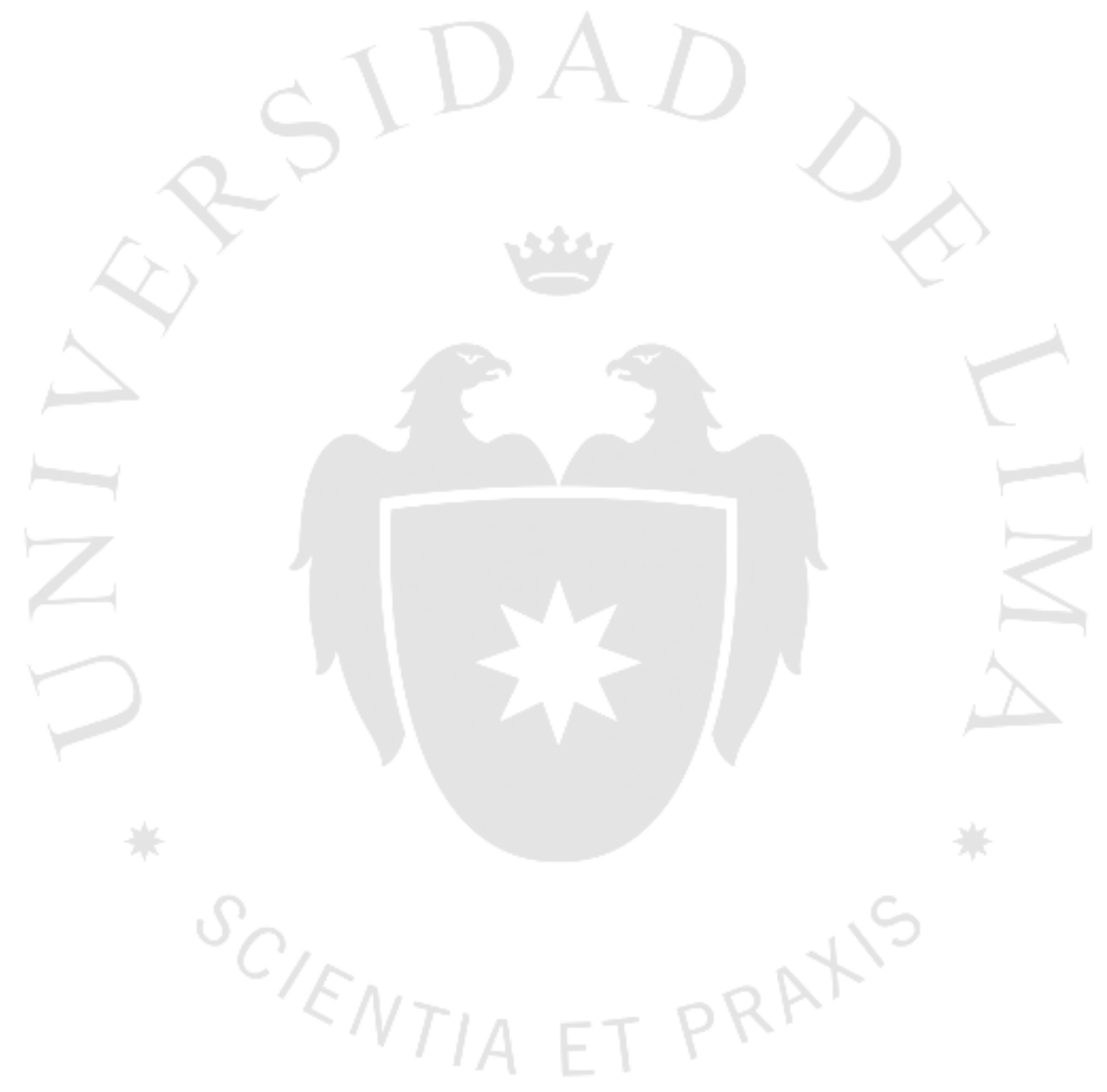




\section{CAPÍTULO I: EVOLUCIÓN DE LA BIOÉTICA TRADICIONAL Y ANÁLISIS ECONÓMICO DEL DERECHO APLICABLE A LA MATERNIDAD SUBROGADA}

En el presente capítulo se realizará un breve análisis histórico de la evolución de la bioética a los efectos de explicar el origen de los principios que usaremos posteriormente como base de nuestro análisis. En el análisis bioético se describirá como dichos principios se aplican en la realidad de la maternidad subrogada y cuáles son sus principales críticas. Finalmente, realizaremos un análisis de dichos principios a través de la perspectiva del análisis económico del derecho a modo que el lector pueda distinguir entre los dos tipos de escuelas: la escuela clásica y la escuela del análisis económico del derecho.

\subsection{Evolución histórica de la bioética}

En la primera parte del trabajo se realizará un breve análisis histórico de las tendencias de la bioética moderna con el objeto de entender el surgimiento de los modelos vigentes de la "bioética" y poder usar como marco de trabajo los principios bioéticos descritos en el Informe Belmont. Asimismo, se hará una breve mención de los principios que serán relevantes en el análisis posterior y su descripción en cada uno de los 4 hitos históricos selectos.

Para el objetivo descrito anteriormente, resulta pertinente la definición previa de dicha disciplina, en ese sentido, hacemos un acercamiento al concepto a través de la definición del primer autor en los Estados Unidos que utilizó el término "bioética" como disciplina especifica; Van Rensselaer Potter, médico oncólogo, el cual, en su libro "Bioética; un puente hacia el futuro" la define como "un estudio sistemático de la conducta humana en el área de las ciencias humanas y de la atención sanitaria, en cuanto se examina esta conducta a la luz de valores y principios morales" (Van Renssenlaer, 1971) citado por (Boladeras, 2004, p. 384). 
Dicho concepto, de acuerdo a Francisco Javier León es sólo un "término nuevo para afrontar una realidad ya antigua" (León, 1995, p. 123), y es que, desde la cultura clásica griega, contamos con el juramento que forma parte del Corpus Hippocraticum o conjunto de escritos atribuidos a Hipócrates, el cual refleja que ya en los valores de aquella sociedad, surge la preocupación por regular la práctica médica, mostrando como valores centrales la búsqueda del beneficio del ser humano y de forma primitiva, el secreto profesional.

Y si bien es cierto que los estudios de la bioética tienen sus orígenes en la filosofía clásica, no es hasta la edad moderna que ocurrieron los grandes cambios de paradigmas en la ética médica tales como: la valorización del consentimiento informado o la equidad en la salud, que, desvalorizados en épocas anteriores, pasaron a formar el eje central de la ética actual.

La Segunda Guerra Mundial y los horrores del Holocausto marcaron un hito en la bioética, por lo que considero que el primer texto a explicar debe ser el llamado "Código de Núremberg", "fuente que inspiró los mundialmente conocidos Informe Belmont y Declaración Helsinki” (Annas, 2004, p. 659).

\subsubsection{Código de Núremberg}

La importancia del "Código de Núremberg", documento publicado en 1947, como punto de partida a nuestro análisis histórico radica en que constituyó la primera vez que se declaró como esencial el uso del consentimiento voluntario del sujeto humano en los experimentos y tratamientos médicos.

Dicho código, “creado como consecuencia de la Segunda Guerra Mundial durante los juicios a los médicos en los tribunales de Núremberg por los experimentos del holocausto, se considera el punto de inicio de la bioética moderna" (Annas, 2004, p. 658).

Entre los principios relevantes detallados en dicho texto recalco:

La necesidad del consentimiento voluntario:

El Código define como esencial en todo procedimiento médico, y describe que, para otorgarse un adecuado consentimiento voluntario, se debe cumplir con las siguientes características; 
“(...) a) Persona en edad legal b) No debe mediar fuerza, fraude, engaño, coacción o algún otro factor coercitivo c) Debe tener suficiente poder de comprensión del asunto (lo cual implica que se debe explicar al sujeto la duración, propósito del mismo, método, inconvenientes y riesgos que puedan derivarse de su participación. d) Limita la responsabilidad a la persona que inicia, dirige o implica a otro en el experimento (...)" (Mainetti, 1989, p. 1).

Revocación del consentimiento:

El código define la conducta en su artículo 10: "Durante el curso del experimento el sujeto humano deber tener la libertad de poder finalizarlo si llega a un estado físico o mental en el que la continuación del experimento le parece imposible." (Mainetti, 1989, p. 1).

La revocación del consentimiento importa en la medida que uno de los temas que más suscita polémica respecto a la regulación del vientre de alquiler, es determinar si la madre gestante debería verse libre de desistir del procedimiento médico (desistir del embarazo) por razones físicas o psicológicas $\mathrm{y}$, hasta que medida debe responder civilmente por aquel acto (si es que debe responder) ante los padres voluntarios.

\subsubsection{Declaración de Helsinki}

El problema del Código de Núremberg, es que si bien consistió el primer intento por crear principios que marcaran la bioética universal, no logró la aceptación necesaria respecto a los aspectos éticos de la investigación humana, razón por la cual:

“(...) en búsqueda de aumentar el consenso, en 1946 se constituyó la Asociación Médica Mundial. Dicha Asociación, en su 8va asamblea general de 1954 adoptó la resolución sobre experimentación humana: Principios para experimentación e investigación humana, que daría lugar a la Declaración de Helsinki en 1964 (...)” (Sierra, 2011, pp. 397-398).

La misma contempla en sus párrafos los siguientes lineamientos:

Protección específica de personas vulnerables: La declaración en su inciso 8 establece que en los tratamientos médicos/investigaciones deben otorgar una especial protección a los grupos y personas vulnerables, y que se deben reconocer las necesidades 
particulares de los que tienen desventajas económicas y médicas. Dicho enunciado guarda profunda relación con el "principio de justicia social y equidad en la salud." (Rawls, 2000, p. 100). El enunciado describe; "Algunos grupos y personas sometidas a la investigación son particularmente vulnerables y pueden tener más posibilidades de sufrir abusos o daño adicional. Todos los grupos y personas deben recibir protección específica.” (Asociación Médica Mundial, 1964, p. 2)

Aquello es importante en razón que las madres gestantes, particularmente "las que provienen de familias de escasos recursos económicos, son propensas a ser parte de un modelo de explotación reproductiva" (Comité de Bioética de España, 2017, p. 24), situación particularmente grave en países como la India “donde se denuncia la existencia de granjas humanas y donde las condiciones de las madres gestantes se asemejan a las de la esclavitud” (Mujer, Madre y Profesional, 2015, pp. 2-3). Ello nos permite observar que las madres gestantes de bajos recursos podrían encontrarse en una situación de vulnerabilidad y la legislación estaría llamada a otorgar una especial protección a las mismas.

Modificación del consentimiento informado en relación al Código de Núremberg:

La declaración establece formalidades al concepto del consentimiento informado estableciendo en su inciso 26 que:

“(...) este debe ser preferiblemente otorgado por escrito, y de no poder ser así, debe ser documentado formalmente ante testigos. (...) Por otro lado, se establece que en caso el paciente se encuentre inhábil física o mentalmente para otorgarlo o al ser legalmente menor de edad, el investigador debe obtener el mismo del representante legal" (Asociación Médica Mundial, 1964, p. 4).

\subsubsection{Informe Belmont}

El informe Belmont, considerado uno de los hitos de la bioética americana, "fue elaborado en abril de 1974 teniendo como antecedente el experimento Tuskegee, experimento en el cual se inoculó el virus de la sífilis a 399 afroamericanos analfabetos con el fin de observar la progresión natural de la sífilis no tratada" (UAB, Fundacio Salut i Envelliment, 1990, p. 51). 
Dicho documento reconoce por sí mismo la inspiración en sus predecesores; el Código de Núremberg y la Declaración de Helsinki, sin embargo, considera que:

“(...) las reglas de estos son inadecuadas o difíciles de interpretar para aplicar en situaciones concretas, o incluso entran en conflicto entre sí, por lo que considera más beneficioso el establecimiento de principios guía que provean bases sobre las que se formularán, aplicarán e interpretarán las reglas específicas" (National Commission for the Protection of Human Subjects of Biomedical and Behavioral Research, 1979, p. 19).

Siendo así, el Informe Belmont enuncia los siguientes principios a modo de orientar la bioética:

\section{Principio del respeto a las personas}

El Informe afirma que dicho principio posee dos convicciones éticas: el respeto a la libre autonomía y la especial protección de aquellos cuya autonomía esta disminuida. La primera es entendida como la "capacidad de deliberar sobre sus fines personales, y de obrar bajo la dirección de esta deliberación." (National Commission for the Protection of Human Subjects of Biomedical and Behavioral Research, 1979, p. 20). Sin embargo, se presupone que esta libertad puede verse perjudicada por falta de información necesaria para elaborar un juicio meditado, disminución mental o circunstancias no explicitas que restrinjan la libertad del individuo. Ante estas situaciones, se aplica la segunda convicción ética, extendiendo protección especial a aquellos que no pueden ejercer su capacidad de autodeterminación de forma correcta.

2. Principio de Beneficencia

El principio de beneficencia se entiende como una obligación en el sentido más radical, y de dicho principio se desprenden dos normas generales:

“(...) no causar ningún daño y maximizar los beneficios posibles y disminuir los posibles daños. Dicho principio, si bien ya se encontraba presente desde el juramento hipocrático, se amplía a contemplar un nuevo supuesto, en el cual, incluso para evitar un daño es necesario aprender lo perjudicial, y dicho aprendizaje puede exponer al riesgo de sufrir daño al paciente" (National Commission for the Protection of Human Subjects of Biomedical and Behavioral Research, 1979, p. 13). 
En las técnicas de reproducción asistida, las cuestiones relativas a su beneficencia son diversas, por ejemplo;

"En un estudio científico realizado en Dinamarca, publicado en la revista Human Reproduction, en el cual se evaluaron 2166 casos, se arrojó como resultado que el riesgo de que un niño concebido mediante reproducción asistida nazca muerto es del 16,2 por mil, siendo este porcentaje en el caso de reproducción natural del 2,3 por mil" (Wisburg, K, Ingerslev, HJ, Henrinksen, TB, 2010) citado por (Cárdenas, Fecundacion asistida y consentimiento informado. Que tan informado es el consentimiento, 2015, p. 25).

Asimismo, en otro estudio que fue promovido por la revista Fertility and Sterility sobre los resultados de las técnicas en Canadá en el año 2006 “se evaluaron 12.052 ciclos de fecundación in vitro, observándose que el índice de embarazos por ciclo iniciado fue de 33,7\% y el de niños nacidos vivos de 27,1\%" (Gunby, Joanne; Bissonnettte, Francxois; Librach, Clifford y Lisa Cowan., 2010) citado por (Cárdenas, Fecundacion asistida y consentimiento informado. Que tan informado es el consentimiento, 2015, p. 25).

Dichos estudios parecen indicar que las técnicas de reproducción asistida son incompatibles con el principio de beneficencia pues parece existir un mayor riesgo para el niño que se encuentra por nacer, en comparación con el beneficio recibido, dado que se trataría de un procedimiento no necesario para conservar la salud del paciente.

\section{Principio de Justicia}

El principio de justicia se entiende en un sentido de "equidad en la distribución", el cual dice que se dará el mismo trato a las personas iguales. Y ¿Qué criterios usamos para distinguir el trato diferenciado? El informe nos dice que hay un acuerdo tácito en que las distribuciones basadas en experiencia, edad, nivel de privación, competencia, mérito y posición pueden ser a veces criterios adecuados para justificar un tratamiento diferencial en ciertos objetivos. Asimismo, la doctrina se orienta a "disminuir las diferencias evitables e injustas al mínimo posible pues se brinda atención en función a la necesidad y se contribuye en función a la capacidad de pago" (Sanabria, 2000, p. 2).

Las técnicas de reproducción asistida contemplan el principio de justicia tanto desde nivel individual, en la forma en la que se obtiene el consentimiento informado de 
las madres provenientes de diferentes sectores de la población, hasta las políticas públicas dirigidas por parte del Estado con el objetivo de confrontar la infertilidad.

En este último caso existen claras diferencias, pues hay autores que afirman que “el principio de justicia no sería aplicable en el caso de dichas técnicas, pues no son una necesidad médica y hay otras necesidades que requieren de manera más prioritaria la financiación del Estado, máxime teniendo en cuenta que los recursos públicos son limitados frente a la interminable cantidad de carencias" (García Delfino, 2013, p. 93).

\subsubsection{Declaración Universal sobre Bioética y Derechos Humanos de la UNESCO}

Si bien el Informe Belmont es un hito en la bioética norteamericana y continúa siendo referencia de las investigaciones y tratamientos clínicos actuales, es un reflejo de una postura puramente norteamericana y no un acuerdo universal. En razón a ello, podemos considerar a la Declaración Universal sobre Bioética y Derechos Humanos de la UNESCO como uno de los más importantes instrumentos universales consagrados a la bioética en el seno de la Comisión de Derechos Humanos de las Naciones Unidas.

Sin embargo, en esa misma línea es necesario precisar que existe un cierto debate con relación a la importancia de dicho documento, pues existen posturas doctrinarias que defienden la obligatoriedad del mismo y otras que entienden que se trataría de "meras sugerencias".

Los detractores de la importancia de dicho instrumento, arguyen que al ser una “declaración no goza del mismo poder vinculante que poseen los convenios o tratados" (Salvador, 2015, p. 449), sin embargo, aun asumiendo dicha postura, su importancia no radicaría en su poder vinculante sino en la elaboración de un documento que estableciese un acuerdo común de todos los países sobre determinados principios bioéticos. Si bien, tiene sus antecedentes en la Declaración Universal sobre el Genoma Humano y los Derechos Humanos de 1997, algunos autores consideran a la Declaración Universal sobre Bioética y Derechos Humanos de la UNESCO “como un punto de corte entre la bioética clásica desprovista de una visión social y política, con la nueva bioética que ubica al hombre en un escenario global junto a sus semejantes" (Salvador, 2015, p. 446). 
Por otro lado, entre los defensores de la obligatoriedad de dicho documento, contamos con un informe oficial de la Asesoría Jurídica del Ministerio de Relaciones Exteriores, la cual expone los tres siguientes argumentos:

El primero se basa en las expectativas de cumplimiento al adoptar una declaración formal:

“(...) la propia práctica de las Naciones Unidas ha ido asentando al respecto una distinción entre recomendaciones y declaraciones, utilizándose el término declaración para encabezar resoluciones que, con carácter formal y solemne, enuncian principios de grande y duradera importancia, creando en el órgano que las adopta una fuerte expectativa que serán cumplidas por la comunidad internacional (...)" (Cárdenas, Temas de Bioética y Derecho, 2008, p. 88).

El segundo en la legitimación en base a la influencia democrática con la cual se adopta el mismo:

"El segundo factor para definir su influencia y autoridad jurídica, sería el apoyo recibido en el momento de su adopción, el cual existe cuando el acto es adoptado por unanimidad o por consenso e incluso, cuando es aprobado por una mayoría de dos tercios, si es que ella es suficientemente representativa" (Cárdenas, Temas de Bioética y Derecho, 2008, p. 88).

Finalmente, el tercero basándose en la costumbre y principios generales del derecho internacional, los cuales otorgan valor jurídico a las declaraciones:

“(...) las referidas Declaraciones tendrían no solo carácter o fuerza normativa, sino que también serían instrumentos jurídicamente vinculantes u obligatorios respecto de los Estados miembros, pues expresarían la convicción jurídica de los mismos en cuanto a la existencia de ciertos principios o reglas de derecho internacional sobre la materia que ya han venido siendo objeto de una práctica, confirmándose el valor jurídico de tales principios o reglas" (Ministerio de Relaciones Exteriores del Estado Peruano, 2007) Citado por (Cárdenas, Temas de Bioética y Derecho, 2008, p. 89).

Siendo de esta forma, sería razonable decir que en nuestro sistema jurídico predomina la postura de la obligatoriedad con relación a dicho tratado y, por ende, resulta 
esencial conocer su contenido. En esa misma línea se indica que dicha declaración de fecha 19 de octubre de 2005 contempla entre otros los siguientes principios:

El respeto a la dignidad humana: Entendiendo que dentro de la misma se encuentran los derechos humanos y la libertad, y que los intereses de la persona tienen prioridad respecto al interés exclusivo de la ciencia y sociedad.

Con relación al contenido del respeto a la dignidad, entendemos que parte de la misma engloba al derecho a la integridad genética, la cual según (Varsi, 2013) puede verse vulnerada en las técnicas de reproducción asistida cuando "existe manipulación genética, cesión de material genético (confunde la filiación), seudofecundacion, transgénesis (seres que en estado embrionario han recibido material genético exógeno mediante métodos artificiales) o incluso durante la selección de embriones por motivos no terapéuticos" (pp. 294-297).

El respeto a la autonomía y responsabilidad individual: Definiendo la misma como el respeto a la facultad de adoptar decisiones, asumiendo la responsabilidad de estas y respetando la autonomía de los demás. Este sin duda es un punto interesante, dado que hay procedimientos médicos como el de la maternidad subrogada, donde la decisión de una persona puede decidir el destino de un no nacido. Ello es relevante en la medida que la declaración entiende que la autonomía será respetada con la limitante que este respeto la autonomía de los demás, aunque el afectado sea un ser dependiente como es un concebido.

Consentimiento informado: Es curioso observar que si bien la declaración admite en su preámbulo “su inspiración en la Declaración de Helsinki” (UNESCO, 2005, párr.7), se da un paso atrás en cuanto a que el consentimiento debe ser preferiblemente escrito. Sin embargo, el mismo sigue conservando su carácter de "necesario en toda intervención médica preventiva, diagnóstica y terapéutica" (UNESCO, 2005, párr.27). Al igual que los anteriores textos, se exige que dicho consentimiento informado deba "ser expreso y sea revocable en todo momento, por cualquier motivo, sin que ello entrañe para ello desventaja o perjuicio alguno" (UNESCO, 2005, párr.27). 


\subsection{Principios de la Bioética aplicables a la maternidad subrogada}

La maternidad subrogada, conocida como vientre de alquiler, se le define como el procedimiento donde una "madre sustituta ofrece su útero para que se desarrolle en éste el embrión concebido extracorpóreamente, para después entregar el bebé a sus verdaderos padres" (Espinoza Espinoza, 2004, p. 121). Por otro lado, también se le define como "el convenio por el cual una mujer se compromete frente a otra $\mathrm{u}$ otras a gestar en su vientre un embrión fecundado extracorpóreamente, ya en forma homóloga o heteróloga, para luego entregar la criatura después del parto"(Peralta Andia, 2004, p. 187).

Sea la definición que adoptemos, la postura de la Bioética en relación a dicho convenio o procedimiento no es uniforme, dado que ha sido duramente criticada desde distintos puntos ideológicos. En los siguientes párrafos, realizaré un análisis de las principales críticas al respecto, usando como marco de trabajo los principios detallados en el Informe Belmont, es decir; el principio del respeto a las personas, el principio de beneficencia y el principio de justicia y como se relaciona el vientre de alquiler con dichos principios.

\subsubsection{El principio del respeto a las personas en la maternidad subrogada}

El principio del respeto a las personas, acorde al Informe Belmont goza de dos vertientes: “el derecho de los individuos de ser tratados como agentes autónomos y que las personas con autonomía disminuida tienen derecho a la protección" (National Commission for the Protection of Human Subjects of Biomedical and Behavioral Research, 1979, p. 34). La maternidad subrogada es un caso donde estos dos principios parecen entrar en conflicto y ello en razón a que la capacidad de elegir libremente de las madres gestantes puede verse mermada tanto por carencia de información (o la llamada asimetría informativa por el Análisis Económico del Derecho) como por situaciones de desventaja económica que favorezcan la explotación de la mujer.

\subsubsection{Principio de Libre autonomía en la maternidad subrogada}

El Principio de Libre Autonomía se desprende del derecho a la libertad, y, por ende, va estrechamente ligado al consentimiento informado. Un adecuado acercamiento al concepto nos lo otorga la definición de Alonso Villarán Contavalli, el cual nos explica sobre el principio de autonomía: 
“(...) La libertad de autonomía se basa en el respeto a la libre autodeterminación del ser humano. Parte de una afirmación arriesgada pero no por ello errada: el ser humano es libre...En el ámbito de la bioética, los autores afirman que esta obligación consiste en el respeto que el médico o científico debe tener de la decisión que adopte el paciente o sujeto investigado frente a las alternativas que se le ofrezcan" (Villarán Contavalli, 2003, p. 21).

En esa secuencia lógica, entendiendo a la libre autonomía como aquella obligación de respetar la decisión del paciente, entendemos que para que el paciente pueda ejercerla correctamente debe gozar de información veraz, clara y exacta, lo cual nos lleva al segundo concepto: El consentimiento informado.

El consentimiento informado, de acuerdo al Documento de las Américas de Buenas Prácticas Clínicas, es el procedimiento mediante el cual "un sujeto confirma voluntariamente su deseo de participar en un estudio o procedimiento particular después de haber sido informado sobre los aspectos de este que sean relevantes para que tome la decisión de participar” (Organización Panamericana de la Salud, 2005, p. 14).

De acuerdo al Dr. Oscar Vera Carrasco en su artículo "El consentimiento informado del paciente en la actividad asistencial médica", los pacientes deben reunir cuatro condiciones para que sus decisiones sean racionales y autónomas (Vera Carrasco, 2016):

“1. Disponer de una información suficiente. No indica que el médico debe otorgarle toda la información que un médico puede suministrarle, el objetivo es que el paciente adquiera una impresión realista sobre su propio estado y una valoración adecuada de las alternativas que le ofrecen. La cantidad de información se puede dosificar cuando por las características del paciente que la entrega de toda la información puede ser perjudicial para el privilegio terapéutico.

2. Comprender la información adecuadamente. Es preciso que la información sea adecuada a la capacidad de comprensión del paciente, el buen profesional debe superar la "dificultad de comprensión objetiva" comunicando correctamente las cuestiones que sean muy técnicas o necesiten conocimientos previos para ser entendidas y las "dificultades de comprensión subjetivas" que van ligadas a la comprensión de cada paciente. En algunos casos, la segunda puede ser insuperable por lo que paciente puede ser considerado como incapaz de decidir

3. Encontrarse libre para decidir de acuerdo con sus propios valores. Dicha condición establece que el consentimiento debe ser otorgado libremente y sin ninguna coerción sobre el 
proceso de decisión del paciente. El mismo debe ser obtenido libre de influencias y la voluntariedad está limitada en menor o mayor medida dependiendo del contexto. Se entiende que en la relación médico paciente existen tres formas de influir en la decisión de las personas: la persuasión, la manipulación y la coacción. En la primera se hace uso de argumentos razonables con la intención de inducir a la otra persona a que tome determinada opción y es considerada éticamente aceptable cuando la argumentación sea leal y no esté sesgada por intereses ajenos al paciente. En la manipulación, el médico le presenta la información al paciente de tal manera que lo empuja a tomar una determinada decisión. Se considera que existe manipulación informacional en la que se falsean datos, desfiguran u ocultan hechos, manipulación psicológica en la que intervienen elementos de los procesos mentales indirectamente relacionados con la comprensión (el tono de voz, gestos, reacciones emocionales) y la tercera que es la manipulación sobre las opciones disponibles, modificando sus características o su atractivo. Todo tipo de manipulación es inaceptable. Y, por último, la coacción que amenazando de forma implica o explicita al paciente con consecuencias no deseadas y evitables si accede a sus requerimientos. Éticamente se considera inaceptable.

4. Ser capaz para tomar la decisión en cuestión. Según la doctrina, solo los pacientes competentes tienen el derecho ético y legal de aceptar o rechazar un procedimiento propuesto. La competencia se define como la capacidad para comprender la situación a la que se enfrenta, los valores que están en juego y los cursos de acción posibles con las consecuencias previsibles de cada uno de ellos para a continuación tomar, expresar y defender una decisión que sea coherente con su propia escala de valores." (pp.60-64)

\subsubsection{Críticas a la libre autonomía en la maternidad subrogada}

A menudo las críticas a la libre autonomía en la maternidad subrogada, provienen de los siguientes argumentos: (1) la madre sustituta no se encuentra libre de decidir dado que se encuentra en una situación de desventaja económica que la obliga a tomar la decisión. (2) la madre sustituta no dispone de información suficiente para tomar la decisión informada

En el primer sector, encontramos la postura feminista que argumenta que la maternidad subrogada es una nueva forma de esclavitud dado que la desventaja económica de la mujer limita su libertad de decisión, obligándola tomar un procedimiento como único método de subsistencia:

“(...) la mujer se ofrece para ser madre subrogada potencialmente podría ser explotada, puesto que, en muchos casos, perteneciendo a la clase social más baja, conciben el servicio 
prestado como uno de los pocos para mantenerse. Un ejemplo tangible nos proporciona la India, donde muchas mujeres son fecundadas con el óvulo de una pareja deseosa de tener un niño, comprometiendo su propia salud sicofísica y sometiéndose a las limitaciones relativas del embarazo. Esta hipótesis es compartida por muchas feministas, tal es el caso de Carol Pateman que define la subrogación de la maternidad como una "nueva forma de esclavitud" (Baffone, 2013, p. 447).

Por otro lado, existe otra postura feminista que defiende a la subrogación de la maternidad como una forma de libre autonomía de la mujer sobre su propio cuerpo:

"La segunda posición entiende a la subrogación de la maternidad como una forma de libre expresión inherente a la mujer, pues esta es un sujeto de libre, autónomo y en grado de asumir plenamente las consecuencias que deriven del acuerdo subrogativo" (Baffone, 2013, p. 447).

Considero que el hecho de permitir la maternidad subrogada no garantiza necesariamente una situación de explotación de la mujer y depende mucho del contexto donde se realice el convenio. Probablemente la situación de la India o países del África o Asia donde abundan las granjas humanas sea mucho más factible hablar de una situación de explotación que en países como Estados Unidos o en un país europeo donde el promedio de la población tiene acceso a un estándar de vida más alto y, por ende, tienen mayor capacidad de decisión. El término granjas humanas, es común en internet, principalmente en páginas web de corte conservador, para referirse a las agencias que mantienen a las madres gestantes, las cuales se dedican exclusivamente a tener hijos razón por la cual se hace la comparación con una "granja".

En el segundo grupo, prolifera la postura que la madre carece de información suficiente para tomar la decisión porque la naturaleza de la obligación le impide conocer las consecuencias de la misma. Dicha postura se encuentra defendida por un sector de la Escuela del Análisis Económico del Derecho que detalla:

"Las partes en ese contrato creen que ellos conocen mejor lo que los beneficia mutuamente y esas ventajas dependen de la obligatoriedad del contrato. Si no es obligatorio, cualquiera de las partes puede cambiar su mentalidad y privar a la otra de los beneficios esperados. La libertad de contratación sugiere que la mujer debe ser libre de disponer de su 
sistema reproductivo como ella desee. Si alguien considera no se les debe permitir a las madres hacer eso, debe ser sobre la base que las madres sustitutas no gozan de la objetividad para disponer objetivamente de sus servicios" (Parisi \& W.F Depoorter, 2001, p. 413).

“(...) Algunos contratos deben ser evitables porque las partes carecen de información necesaria para hacer una elección racional. Mi argumento es que, en los contratos de subrogación, las decisiones son sub-optimas porque el subrogante no puede conocer correctamente o al menos tener información mínimamente adecuada de los efectos de su decisión (...)” (F.Brining, 1995, p. 2388).

Es decir, dicho sector argumenta una situación de asimetría informativa en razón a que la madre no podrá prever el costo emocional de desprenderse del hijo, ocasionando que jamás pueda tomar una decisión de dicha naturaleza con el apropiado consentimiento informado.

1.2.1.3 Límites a la libre autonomía de la mujer en los procedimientos de maternidad subrogada

Uno de los temas más importantes en cuanto a la legislación sobre la maternidad subrogada es determinar si la madre sustituta tendría la capacidad para revocar o no su decisión y suspender el embarazo. Como sabemos, "la libertad no es un derecho absoluto y se encuentra limitada por el derecho ajeno" (García Maynez, 1941, p. 107), en este caso la decisión de la madre sustituta tiene graves repercusiones (sobre la vida) del ser que guarda en su vientre, razón por la cual el ejercicio de la total y libre autonomía de la mujer en los procedimientos de maternidad subrogada es algo por lo menos, polémico. El Dr. Marcial Rubio define bien la posición al respecto:

“(...) No podrá revocarse la aceptación: a) después de iniciados los procedimientos biológicos que conducen ineludiblemente a la concepción y mientras ellos no se encuentren fallida b) desde que la concepción se ha producido mientras existe vida humana a partir de ella (...)" (Rubio Correa, 1996, p. 92).

Detallando la importancia del interés superior del niño en dichos procedimientos, y que el mismo debe prevalecer al interés de los padres: 
"En la resolución de cualquier problema referente a la reproducción humana asistida, deben ser tomado en cuenta los intereses de quienes participan en el hecho y también los del nuevo ser humano que emergerá...En caso de conflicto debe prevalecer el interés objetivo del nuevo ser humano, que será deducido del contenido de los derechos humanos y reglas existente sobre el tratamiento de menores" (Rubio Correa, 1996, p. 191).

En cambio, la postura favorable a que la mujer ejercite el consentimiento en cualquier parte del embarazo proviene de un sector del análisis económico del derecho que argumenta lo siguiente:

“(...) la revocación del consentimiento es válida dado la naturaleza imperfecta de dicho tipo de contratos, la cual impide que la madre goce de información suficiente acerca del trauma de dar a luz a un niño y entregarlo a la madre subrogada (...)" (G.York, A contractual analysis of subrogate motherhood and proposed solution, 1991, p. 404).

Sin embargo, de aceptar esta última hipótesis, estaríamos entendiendo que las mujeres serían incapaces de tomar decisiones donde la carga emocional sea mayor de la esperada. Ello puede llevar a injustas y discriminatorias restricciones de libertad.

\subsubsection{El principio de beneficencia}

El principio de beneficencia es uno de los primeros principios reconocidos por la escuela clásica de la medicina. Encontramos que desde los escritos de Hipócrates se encontraba la siguiente expresión: "Voy a definir lo que considero que es la medicina: el apartar por completo los padecimientos de los que están enfermos y mitigar los rigores de sus enfermedades, y el no tratar a los ya dominados por enfermedades, conscientes de que en tales casos no tiene poder la medicina" (Beauchamp, 1987) citado por (Postigo, 2006, p. 1).

Asimismo, contamos con la definición otorgada por Alonso Villarán Contavalli:

"El principio de beneficencia postula, en palabras simples, que el médico o científico se encuentra en la obligación de hacer bien al paciente o sujeto investigado, es decir, que debe procurar su bienestar. Este principio es confundido con el de no maleficencia, sin embargo, creemos que se trata de dos visiones de un mismo deber, el deber de hacer el bien implica de manera obvia y necesaria que no se hará el mal. En cuanto el deber de no hacer el mal, no exige 
necesariamente hacer el bien, pues yo puedo no hacer daño a nadie sin que ello implique que estoy haciendo el bien" (Villarán Contavalli, 2003, p. 16).

1.2.2.1 Riesgos del procedimiento de la maternidad subrogada

Con relación al principio de beneficencia en la maternidad subrogada, los riesgos pueden ser asumidos en razón a un beneficio. Con la madre, más allá de los riesgos físicos que son comunes al embarazo, estos son más de orden psicológico. Como manifiesta Antonio Cabrera las consecuencias de recurrir a las técnicas de reproducción asistida:

“(...) implica procesos largos y penosos. Es un camino de decepciones y esperanzas que puede implicar varios años de la vida de la mujer y de su pareja (...) La presión psicológica a la que se enfrenta la pareja, en especial la mujer, es muy desgastante, pues el procedimiento (...) está lleno de inquietudes, sufrimientos, angustias, miedos, además de soportar los efectos de los medicamentos y enfrentarse a procedimientos fuertemente invasivos. (...)" (Cabrera, 2011. p.34) citado por (Cárdenas, 2015, p. 23).

Asimismo, la Dra. Teresa de Jesus Seijas Rengijo, en una sección de su libro “Aspectos Psicológicos de la Reproducción” nos explica los riesgos psicológicos que atraviesan los padres en las técnicas de reproduccion asistida en general:

"La inseminación artificial homóloga trae consecuencias no deseadas, la mujer inseminada artificialmente por donante heterólogo presenta mayores consecuencias negativas: a)Incertidumbre por las características y probables taras genéticas de su producto b) deseo de conocer al verdadero padre c) alteraciones en su vida sexual y familiar con la pareja al cual puede llegar a rechazar d) actitudes y conductas deshonestas con la finalidad de conocer la identidad del donante e) sensación de adulterio f) rechazo al producto (...)" (Seijas Rengifo, 1998, pp. 121122).

Finalmente, entre los riesgos propios de la maternidad subrogada encontramos que el más grande es sin duda el costo emocional afrontado por la madre de alquiler al desprenderse del hijo. Se entiende que eso es debido a que durante la gestacion, la mujer atraviesa un proceso neurobiológico natural que configura su cerebro en un "cerebro materno". Ello crea un vínculo entre la madre y el hijo conocido como "vínculo de apego afectivo y emocional". Dichas relaciones no son fáciles de ignorar y como hemos descrito 
anteriormente, algunos autores consideran que "el desprenderse del hijo gestado puede ser considerado un trauma psicológico para la madre sustituta" (Think Action Development, 2013), y pueden dar origen a casos como el afamado "Baby M" donde "la madre sustituta intentó escapar del pais con el bebé que se encontraba gestando" (G. Basterra, 1997).

Asimismo, acorde a los estudios citados anteriormente sobre tasa de niños nacidos vivos en Dinamarca y Canadá en procedimientos de técnicas de reproducción asistida e inseminación in vitro en comparación con las concepciones naturales (Wisburg, K, Ingerslev, HJ, Henrinksen, TB, 2010) citado por (Cárdenas, 2015, p. 25) y (Gunby, Joanne; Bissonnettte, Francxois; Librach, Clifford y Lisa Cowan., 2010) citado por (Cárdenas, Fecundacion asistida y consentimiento informado. Que tan informado es el consentimiento, 2015, p. 25) nos dan a entender que recae un mayor riesgo físico sobre el niño en esta clase de procedimientos.

En esa misma línea, un sector de la doctrina argumenta que el riesgo del niño no solo sería de orden físico sino también psicológico. La más conocida es la "teoría de programación fetal" la cual argumenta que él bebé se acostumbra y desarrolla un vínculo con la madre desde el desarrollo embrionario y el ambiente donde se inicia su existencia. El vínculo es tan poderoso que tanto las emociones de la madre influyen en la formación del mismo y la salud mental infantil (Fernández I. O., 2004, pp. 6-8). Basándose en esa lógica, al ser desprendido de "su ambiente" puede sufrir daños psicológicos que afectarían su vida adulta.

\subsubsection{Beneficios en los procedimientos de maternidad subrogada}

En razón a los riesgos antes mencionados, lo más razonable sería que estos procesos se usen solamente cuando exista un beneficio cierto, es decir, una de las madres sea estéril y sea la única forma de procrear, y no como un método para evitar simplemente las incomodidades del embarazado. El Dr. Gustavo Silva Peñaranda ilustra bien esta posición:

"Podrá autorizarse la gestación en la mujer sola por medio de estas técnicas, si padece una esterilidad irreversible que la justifique, y con cargo al erario público. Este artículo permite que una mujer sola pueda convertirse en una madre gestante, pero no cualquier mujer, sólo la que demuestre que tiene una esterilidad irreversible... No cuestiona los posibles problemas psicológicos que tendrían los niños concebidos y criados de manera voluntaria sólo por la madre 
y no porque el padre no quiera hacerse responsable. Esto permitiría que cualquier mujer que no desee tener contacto sexual con un varón, pueda gestar individualmente con técnicas de reproducción asistida (...)” (Sivila Peñaranda, 2004, p. 80)

Asimismo, Luis Santa María Solís nos informa que las técnicas de reproducción asistida no se pueden considerar métodos terapéuticos por lo que es cuestionable el beneficio de dichos procedimientos:

"Sería equivocado presentar estas técnicas como tratamientos de la esterilidad masculina o femenina. Las TRA no se pueden considerar métodos terapéuticos en el sentido habitual ya que no curan la infertilidad, el paciente estéril porque tiene una alteración testicular importante o la paciente con una estenosis bilateral de las trompas uterinas, siguen con su problema orgánico tras la utilización de las TRA” (Santamaria Solis, 2000, p. 38).

Sin embargo, más allá de no curar un mal físico, es importante recalcar que el beneficio de la maternidad subrogada seria más de orden psicológico. Procrear es parte esencial en la vida del ser humano y de su desarrollo como persona, y el permitir que una pareja infértil goce de la posibilidad de tener un hijo cubre uno de los aspectos vitales en su identidad.

\subsubsection{El principio de justicia}

El principio de justicia es sin duda uno de los principios más polémicos en cuanto a su aplicación en la maternidad subrogada. Su noción implica una intervención del Estado como ente llamado a salvaguardar dicho valor, tanto a nivel macroeconómico como sería el caso de las políticas públicas, como a nivel microeconómico que sería el caso de las relaciones entre particulares (entendiendo si la madre subrogada debe ser considerada un sujeto vulnerable que debe otorgársele especial protección) tema tratado anteriormente en el apartado 1.2.1 El principio del respeto a las personas como una de las críticas a la libre de autonomía a la mujer.

La socióloga Marcela Ferrer Lúes, en su artículo "Equidad y Justicia en la salud: Implicancias para la Bioética" nos da una adecuada visión acerca de la implicancia de dicho principio:

"Desde hace varios años, pero especialmente durante la última década, se ha demostrado que existen importantes diferencias en el estado de salud de las personas según distintos atributos socioeconómicos, sociodemográficos, geográficos, étnicos o de género. La difusión sistemática 
de estas diferencias ha permitido que el logro de la equidad en salud (valoración ética de estas diferencias) se transformara en uno de los principales objetivos de las agendas de los gobiernos y de los organismos internacionales (...)" (Ferrer Lues, 2003, p. 114).

Posiblemente, las más grandes dudas al respecto se plantean con relación a que si el Estado debería brindar acceso a los que poseen menos recursos económicos a dichos procedimientos. Entre los argumentos que se oponen a dicha opción los encontramos de dos tipos: los que afirman que conduce a un ineficiente consumo de recursos y los que afirman, que existen necesidades más prioritarias.

Entre los primeros, la jurista María García Delfino en su artículo "Nuevas perspectivas sobre la financiación pública de las técnicas de reproducción" nos dice lo siguiente (García Delfino, 2013):

"Existe un problema de asimetría de información con respecto a la infertilidad debido a que la OMS la define como la imposibilidad de lograr un embarazo clínico luego de un periodo de 12 meses o más de relaciones sexuales regulares sin anticonceptivos, es probable que existan situaciones donde no se ha concebido en ese periodo sin que signifique propiamente “infertilidad”. La utilización de la definición de infertilidad basada en el tiempo (...) provoca problemas en su aplicación práctica (por ejemplo, genera problemas de asimetría información; en casos de "infertilidad inexplicable", etc.) y posibilita el engaño para acceder a las TRHA, conduciendo a ineficientes niveles de consumo de los servicios" (pp. 90-91).

En el segundo grupo, se encuentran argumentos de distinta naturaleza. Entre ellos, se considera que la infertilidad no es una enfermedad que necesite ser curada para salvar la vida: "Bien podríamos concluir que, si la infertilidad no es una enfermedad en sí misma, las TRHA, FIV especialmente, no podrían considerarse una necesidad para la salud (claramente, no son un tratamiento para una "enfermedad" que atente contra la vida)" (García Delfino, 2013, p. 91).

No obstante, a mi parecer, el argumento más fuerte proviene de la premisa de que existen necesidades más apremiantes:

"Hay posiciones que consideran que las TRHA son una necesidad médica, pero que hay otras necesidades que requieren de manera más prioritaria la financiación del Estado. Máxime 
teniendo en cuenta que los recursos públicos son limitados y escasos frente a la interminable cantidad de carencias o mejores esperadas por la población" (García Delfino, 2013, p. 93).

Incluso, las posiciones que defienden el uso de técnicas de reproducción asistida en general, argumentan que debe realizarse solo en caso de esterilidad irreversible, lo cual, como se ha dicho anteriormente es imposible de determinar.

"Podrá autorizarse la gestación en la mujer sola por medio de estas técnicas, si padece una esterilidad irreversible que la justifique, y con cargo al erario público. Este artículo permite que una mujer sola pueda convertirse en una madre gestante, pero no cualquier mujer, sólo la que demuestre que tiene una esterilidad irreversible (...)" (Sivila Peñaranda, 2004, p. 80)

Parece ser que la mayoría doctrinaria, asume que existen distintos problemas en la aplicación de dicho principio en la maternidad subrogada y descarta que el Estado deba intentar suplir las desigualdades propias de la infertilidad en la población otorgando acceso a dicho procedimiento. Por otro lado, una postura inteligente acerca de la labor que el estado debería tener en estos casos me parece la asumida por la jurista (García Delfino, 2013):

“(... 1-Impulsar y destinar más recursos a la investigación de las causas de la infertilidad, y al desarrollo de la cura de las distintas disfunciones que puede ocasionarla (...)

2-Adecuado acceso a la información, conociendo medidas para prevenir la infertilidad (es esencial que una política pública sobre infertilidad incorpore un elemento preventivo (...)

3-Trabajando a nivel educativo, fomentando una valoración y cuidado de la fertilidad, promoviendo educar sobre las causas de infertilidad y la realización de programas pendientes a prevenir comportamiento que incrementen las causas de infertilidad (...)

4-Impulsar la adopción como opción preferencial frente a los casos de imposibilidad de concepción natural es una política pública en beneficio de la niñez y la familia... a la par que soluciona simultáneamente el problema de la niñez en desamparo y el deseo de los padres de tener un hijo (...)" (pp. 102-103).

Como se observa, la postura más razonable debido al costo y las prioridades de gastos públicos, es que los recursos del Estado se destinen a una función preventiva de la 
infertilidad, en lugar de asumir una postura "analgésica" por llamarlo así, dado que las técnicas de reproducción asistida no logran "curar" la infertilidad, simplemente tratan los síntomas.

\subsection{Análisis Económico del Derecho aplicado a la maternidad subrogada}

La disciplina del Análisis Económico del Derecho (en adelante expresado bajo las siglas AED) se originó en Inglaterra más llego a su más álgido desarrollo en Estados Unidos de la siguiente manera:

"Tiene sus orígenes desde finales del siglo XVIII, donde el filósofo Adam Smith advertía de la existencia de las llamadas "leyes de pobres" (leyes de asistencia social) que inhibían el desarrollo económico de Inglaterra. Asimismo, en 1776 el fisiócrata Nicolás Baudeau planteó la idea de "legislación económica" como el hecho que toda actividad en la sociedad se regía por una constitución económica. Ello, llevaría a que Pierre-Joseph Proudhon un siglo más tarde utilizara la noción de derecho económico, según la cual, el derecho buscaba resolver las contradicciones de la vida social reorganizando la sociedad" (Arjona Trujillo \& Rubio Pardo, 2002, p. 119).

Posteriormente, en los Estados Unidos se fue consolidando lentamente. Según (Arjona Trujillo \& Rubio Pardo, 2002) “primero con el estudio de casos judiciales como fuente de información para el estudio de algunos actores económicos (principalmente los casos anti-trust) para posteriormente ahondar en la tendencia actual, es decir, la que ahonda en el campo de las relaciones jurídicas como una extensión del enfoque económico del comportamiento humano" (p. 120).

Como podemos observar, la relación entre Economía y Derecho ha sido tratada desde diferentes perspectivas a lo largo del tiempo, sin embargo, por motivos prácticos para el presente análisis usaré la definición del Profesor. Gabriel Doménech Pascual, la cual nos dice: "El AED consiste en estudiar-bien con una finalidad práctica, bien con una finalidad puramente cognoscitiva-las normas jurídicas aplicando los conocimientos y métodos proporcionados por la economía” (Domenech Pascual, 2014, p. 101). Dicha definición, al ser bastante amplia me permite ahondar en un aspecto el cual, según mi opinión, ha sido olvidado por las escuelas del análisis económico del derecho: el análisis macro económico. 
La economía se encuentra dividida en dos terrenos de investigación: la microeconomía y la macroeconomía:

"Mientras la microeconomía se focaliza en las acciones de los individuos como agentes a través de la economía; es decir, el individuo, sus motivaciones y conducta, la macroeconomía entiende a la economía como un todo; se focaliza en los estándares de vida de una nación, la cantidad de bienes y servicios que una nación produce en determinada industria." (A. GreenLaw \& Taylor, 2014, pp. 12-15).

La literatura del AED se ha centrado comúnmente en los individuos como actores del mercado y no como estos operan en su conjunto en la economía de un país, lo cual, a mi parecer, debería ir acompañado de un análisis social dado que los individuos no somos seres racionales individuales, sino nuestras decisiones se encuentran afectadas por el contexto social donde nos desenvolvemos.

\subsubsection{Críticas al Análisis Económico del Derecho aplicable a la maternidad subrogada}

Entre las principales críticas al AED, encuentro tres que resultan necesarias de tratar a modo breve antes de mostrar los argumentos que expone dicha escuela: a) las personas no siempre actúan racionalmente, b) la eficiencia lo es todo, c) hay esferas de la actividad humana no susceptibles de análisis económico.

a) Las personas no siempre actúan racionalmente

La psicología nos muestra que las personas en determinadas condiciones actúan de forma distinta a la que podría ser el modelo teórico de la elección racional (debido a que poseen una racionalidad limitada) y ello ocasiona que existan errores al momento de formular sus juicios sobre los costes y beneficios de su conducta.

Sin embargo, ello no resta validez al AED dado que "las anomalías son predecibles y pueden tener un impacto significativo en la conducta humana, lo que nos llevaría a ajustar los modelos teóricos del AED para reflejar dichas anomalías y predecir mejor cómo funciona la gente frente a las normas jurídicas" (Arjona Trujillo \& Rubio Pardo, 2002, p. $125)$. 
b) La eficiencia lo es todo

Se ha criticado constantemente que la eficiencia es el único objetivo de las normas jurídicas y ello causa un conflicto con la justicia distributiva. Ello, es una solo posición del AED. Incluso Richard Posner, sostuvo que "la maximización de utilidad no puede ser entendida como sinónimo de felicidad, sino la maximización de la riqueza entendida como lo que los hombres pagarían por los bienes existentes.” (Posner, 1985, p. 86)

Dicho criterio "coincide con la eficiencia de Kaldor-Hicks, la cual describe que un resultado es más eficiente que otro si quienes ganan con él, pueden compensar a los que pierden de modo que nadie salga perjudicado, si bien no es necesario que los compensen efectivamente. (Domenech Pascual, 2014, p. 128).”

Asimismo, se acepta que existen distintas formas de distribución de riqueza, y que no es necesario que cada una de las normas jurídicas se diseñe con ese objetivo. En ciertas ocasiones, como expresa (L.P.Piffano, 2012) “emplear solamente los sistemas tributarios y de protección social pueden ser ideales para corregir desigualdades" (pp. 20-22).

c) Hay esferas de la actividad humana no susceptibles del análisis económico

Este es quizá, uno de los argumentos más fuertes de la no pertinencia de dicho enfoque en la maternidad subrogada. Se argumenta que "tratar regulaciones del derecho de familia podría llevar a mercantilizar objetos que se encuentran fuera del comercio, como sería el caso de los hijos fruto de dicha clase de convenio" (Sivila Peñaranda, 2004, p. 79).

Sin embargo, este argumento presenta una falacia: el objeto en los contratos de maternidad subrogada no es el niño sino la capacidad de gestar. Es decir, el subrogante no puede vender al niño porque "no lo tiene", por el contrario, solo puede vender lo que, si tiene, que es ceder temporalmente el uso de su vientre con fines gestacionales. El AED argumenta que "el objeto del contrato es el servicio de transferir a otra persona el uso de los cuerpos, y es válido como sería el caso de las nanas, comadronas, modelos, actrices, trabajadores manuales y soldados" (N.Hatzis, 2003, p. 420).

Existe un sector de la escuela del AED que va un paso más allá, y argumenta que:

“(...) en los casos donde la mujer está contribuyendo más que con la labor de gestar, ella está vendiendo su material genético y se vuelve difícil reconocer cuando el intercambio escapa de una venta de bebé. Adicionalmente, se afirma que se venden los atributos personal de 
la mujer- raza, peso, color de cabello, inteligencia, habilidades artísticas en conjunto con su capacidad reproductiva, y en una sociedad donde los cuerpos de las mujer son cosificados por los anuncios, industria pornográfica, promotores de prostitución estos atributos son palpables y tienen un valor (...)” Margaret Radin citada por (Lyndon, 2011, p. 625).

Sin embargo, considero que este argumento es aplicable análogamente a otras industrias como la del cine, donde estos valores de belleza, tipo de cuerpo, color de cabello, forman parte de la industria y gozan de un precio establecido (ejemplo: La cantidad que están dispuestos a pagar los directores por una actriz con determinadas características físicas y habilidades para interpretar a un personaje) y no por eso se afirma que se desvirtuaría en trata de personas.

\subsubsection{Microeconomía}

La microeconomía como fue mencionado anteriormente, se dedica a estudiar a los agentes económicos individuales, por lo que en el presente subcapítulo procederé a describir las posiciones del AED con relación a los siguientes tres agentes: la madre gestante, los padres voluntarios, las agencias de maternidad subrogada y como afectan sus decisiones en el mercado.

\subsubsection{La madre gestante}

La madre gestante, acorde a la definición de Juan Espinoza es "la madre que acepta ser inseminada artificialmente y cede su útero a fines de gestar un bebé que será posteriormente entregado a los padres voluntarios" (Espinoza Espinoza, 2004, p. 121). La postura liberal en el AED argumenta que los contratos de subrogación "son un canal efectivo que permite el intercambio de recursos escasos (la capacidad reproductiva en este caso) dirigiéndonos a la satisfacción de necesidades individuales (no necesariamente materiales, en este caso la procreación)" (Bullard, 2009, p. 56). Además, asegura que tiene el mérito de asignar recursos sin intervención del Estado ya que basta con que estos sean permitidos y obligatorios para brindar sus beneficios.

El jurista Alfredo Bullard, ilustra dicha postura en su libro Economía y Derecho:

"Si aceptáramos que el Derecho contractual puede entrar a jugar en este campo, estaríamos permitiendo que un recurso escaso (capacidad reproductora individual) sea transferida vía el mercado a personas que carecen de ella o que, teniéndola, la pueden ejercer a muy alto 
costo. Esta transferencia puede ocurrir sólo en tanto quien cede su capacidad la valore menos de lo quien desea tal capacidad está dispuesto a pagar" (Bullard, 2009, p. 56).

Dicho criterio permitiría alcanzar el conocido “Óptimo de Pareto" el cual nos dice que "los seres racionales buscan su mutuo beneficio y al liberar de trabas sus relaciones contractuales, ellos regularán sus intereses de la forma que mejor consideren conveniente.” por (Otilio Reyes \& Franklin Sam, 2014, pág. 217)

No obstante, en la doctrina del AED encontramos objeciones a dicho enunciado y los argumentos se desprenden principalmente de dos lados: los que argumentan la existencia de una asimetría informativa que impediría que la madre goce de información suficiente para tomar una decisión optima y los que argumentan que la madre toma una decisión subóptima causada por un estado de necesidad que favorece su explotación.

En la primera postura, se afirma que ninguna madre puede gozar de la madurez suficiente para conocer el costo emocional de desprenderse del hijo a menos que lo haya sufrido en carne propia, razón por la cual, su decisión se encontraría sesgada por la información insuficiente tomada al momento de aceptar el convenio. (Margaret Friedlander Brinig, 1995) nos explica dicha posición:

"La contratación provee eficiencia independientemente de la asignación de los derechos de propiedad mientras los costos de transacción sean bajos. Pero hay límites para los contratos, incluso en el mundo del análisis económico del derecho. Algunos contratos no están permitidos por razones morales u otras sociales. Algunos se convierten en anulables (son menos que perfectos) porque las partes no tenían suficiente información para tomar una decisión racional. Mi argumento es que los contratos de subrogación son subóptimos porque el sustituto no puede tener una información perfecta, o incluso mínimamente adecuada (...)” (Friedlander Brinig, 1995, pág. 2387).

Del mismo modo, Stephen G. York menciona sobre el error de Posner:

"El segundo error de Posner es la racionalización que la mayoría de madres subrogantes son madres maduras con niños y por ello son capaces de tomar una decisión informada. La madurez de las madres, sin embargo, no es parecida a tomar una decisión completamente informada. A pesar de la publicidad alrededor de los casos de nacimientos como el del Baby B, 
el trauma resultante del nacimiento de un niño y su posterior desprendimiento solo puede ser experimentado cuando ya se ha estado en la situación. La publicidad sobre el daño potencial no hace a las futuras madres subrogantes completamente informadas" (G.York, 1991, p. 404).

Alfredo Bullard considera que dicho argumento, si bien es "humanamente entendible, seria paternalista y convertiría en incapaz a la madre para tomar ciertas decisiones" (Bullard, 2009, p. 59). Cabe recalcar que, si bien dicho autor no niega la relevancia del dolor emocional de la madre, lo considera un costo necesario de dicho tipo de contratos.

Por otro lado, Arístides N. Hatzis considera que es inevitable la existencia de incertidumbre en los contratos:

"Todos esos problemas son básicamente los resultados del paso del tiempo, que es un elemento sine qua non de cualquier contrato, y es inevitable la falta de perfecta información entre los participantes. La escasez del tiempo y dinero hace virtualmente imposible que las partes consigan designar responsabilidad por cada posible contingencia debido a la incertidumbre diferida en el intercambio" (N.Hatzis, 2003, p. 424).

En la segunda postura, encontramos los autores que argumentan que la maternidad subrogada se aprovecha de un estado de necesidad en la mujer que le impediría tomar una decisión óptima y favorece su explotación. Ante dicho argumento, tomamos de nuevo la opinión de Arístides N. Hatzis cuando nos menciona que es necesario que el contrato sea vinculante pues las dos partes obtienen beneficios. "Las madres gestantes ven la subrogación como una oportunidad para obtener una suma de dinero que les va a permitir elevar su estatus de vida a ella y el de su familia, posiblemente ofrecerles una mejor educación y salud a sus hijos." (N.Hatzis, 2003, p. 417)

Dicho autor, además, postula que no ve porque no se debería aceptar un acuerdo “en desesperación” pues afirma que la única solución financiera para evitar contratos en desesperación, sería una "red de seguridad". Si no existe dicha red de seguridad y no se permite la subrogación, se condenaría a la pobreza a las madres subrogadas, privándolas de comida por proteger un estándar de moral que busca evitar perjudicarlas (N.Hatzis, 2003, p. 423). 
Asimismo, el abogado Stephen G. York siguiendo a Richard Posner, afirma que:

“(...) la prohibición de los contratos de maternidad subrogada solo causará una situación de desventaja en las madres gestantes, pues al causar más incertidumbre disminuirá su poder de negociación, condenándolas a una situación de explotación donde deban cobrar precios más bajos para conseguir el estándar de vida que buscan con dicha actividad, ocasionando lo que se buscaba evitar con la prohibición" (G.York, 1991,p.404).

Debido a ello, existe una tendencia que considera que la mejor forma de evitar la explotacion de las mujeres en este tipo de contratos es permitiendo que "se realicen de forma altruista, es decir, las madres reciban una compensacion por sus servicios pero evitando que puedan lucrar con dicha actividad" (V.Mc Lachlan \& Swales, 2009).

En relación a este argumento, Aristides N. Hatzis nos menciona que se estaría olvidando el "costo de oportunidad" asumido por la madre. Dicho autor afirma que:

“(...) inclusive el lado más reservado asume que las madres gestantes deben ser compensadas por gastos médicos de hospital o incluso de viajes si fuese aplicable. Sin embargo, existe el problema con la pérdida de salarios, la comida nutricional, ropas de maternidad. ¿Hasta que punto la maternidad es considerada comercial? Si incluimos el costo de oportunidad (el cual debe ser incluido si lo que se busca no es castigar una conducta altruista) la diferencia en el valor de mercado seria minima o cero" (N.Hatzis, 2003, p. 421) .

Cabe indicar, que los contratos de subrogacion altruistas, especialmente en paises con poca presencia estatal, son dificiles de monitorear. El costo de "rastrear regalos, depósitos y sus motivos entre los padres voluntarios y las madres de alquiler resultan altos y poco productivos" (Rammonhan \& Kare, 2013, pp. 47-48).

Como podemos observar, la situación de las madres gestantes es entendida como "vulnerable" en esta clase de contratos y la tendencia apunta a proteger a dicha madre de la explotación de su cuerpo y la falta de información acerca del costo real de dicha operación. No obstante, prohibiendo la contratación o eliminando el elemento del lucro, solo se consigue perjudicarles pues: les resta poder de negociación, obligándoles a reducir sus precios y alcanzando posiciones menos satisfactorias. Evita que eleven el nivel de vida de su familia negándoles un necesario ingreso de dinero por un servicio que ellas se encontrarían dispuestas a realizar, y negándoles su capacidad jurídica para determinados contratos, restringiendo su libertad. 


\subsubsection{Los padres voluntarios}

Los padres voluntarios se definen como aquellos que buscan la paternidad del bebé que nacería por medio de los convenios de maternidad subrogada. Considero que es preferible dicho término al de "padres genéticos" pues en algunos casos la maternidad subrogada se da en conjunto con una inseminación heteróloga (es decir, uno de los gametos es de un tercero) y dicho término excluye a la parte de la pareja que no aportó el gameto y resultaría impreciso.

La prohibición en los contratos de maternidad subrogada genera un desincentivo para los padres voluntarios que desean cumplir el contrato y un incentivo para aquellos que incumplirlo. Ello debido a que los primeros "se ven perjudicados al afrontar mayor riesgo de una eventual rescisión de la madre, lo cual los lleva a recurrir a agencias en busca de garantías (incrementando sus costos) o a pagar montos reducidos a las madres subrogadas" (Posner, 1989, pp. 22-23). Por otro lado, "la falta de regulación constituye un beneficio para los padres que podrían incumplir su contrato, ya sea porque consideren que el costo asumido ha sido muy alto, o porque el niño por nacer va a ser discapacitado o experimente dificultades durante el matrimonio" (N.Hatzis, 2003, p. 425).

Cabe recalcar que el principio descrito anteriormente aplica también cuando la legislación permita celebrar dicha clase de convenio, sin embargo, también permite que la madre gestante revoque su consentimiento en cualquier momento. En este último caso, se presenta la oportunidad de ejercer un abuso una vez iniciado el procedimiento, donde se podría presentar una situación de extorsión donde la madre incremente el costo bajo pena de interrumpir su embarazo, como fue el caso de la Casación 563-2011 en nuestro país.

Adicionalmente, considero que su poder de negociación es bastante fuerte, pues así se encuentre prohibido en la legislación de su país, los mismos pueden viajar a un país donde se encuentre permitido (es razonable pensar que el consumidor de dicha clase de convenios tiene el poder adquisitivo suficiente para viajar a otro país donde la legislación sea más permisible en caso no encontrarse contento con las ofertas vistas). Esta realidad, ha causado la creación de un concepto bastante popular en los medios de comunicación, el de "El turismo reproductivo", para definir "el movimiento de personas fuera de su lugar de residencia en busca del tratamiento de reproducción asistida que suponga la solución a sus problemas de fertilidad" (Fernández, 2017, párr.1). 
En ese sentido, la posición de los padres voluntarios es entendida como la posición más fuerte en dichos contratos debido a que usualmente su poder adquisitivo les permite acceder a una oferta más grande (moverse al mercado de distintos países en caso encontrar disconformes con la oferta en su país). Por el contrario, la posición de la madre gestante y su poder de negociación es menor, dado que usualmente son mujeres en situaciones de necesidad. Sin embargo, una vez iniciado el tratamiento son vulnerables a las decisiones de la madre gestante (bajo costo de perder el tiempo de búsqueda del hijo, o incluso la vida de su hijo en caso la mujer aborte) por lo que la capacidad de la mujer de revocar su consentimiento en cualquier momento (sea para interrumpir el embarazo o por no entregar al bebé) ocasiona que incurran en costos adicionales para asegurar el cumplimiento del contrato, como sería recurrir a las agencias de maternidad subrogada.

\subsubsection{Agencias o Corredores de maternidad subrogada}

Las agencias de maternidad subrogada o vientre de alquiler se definen como empresas que se dedican a seleccionar a potenciales mujeres que desean ser madres de alquiler para ayudar a unos futuros padres tener un hijo. "La agencia pone en contacto a futuros padres con las madres subrogadas y hace un seguimiento de todo el embarazo hasta que el bebé es entregado a los futuros padres. Estas agencias se encuentran en el país donde es legal la maternidad subrogada y normalmente trabajan con clínicas, abogados y psicólogos" (San Diego Fertility, 2015, párr.4).

Dichas agencias han sido injustamente tratadas en la escuela del análisis económico del derecho como entes que aprovechan a la situación de las madres y aumentan los costos de transacción. Sin embargo, la existencia de estos agentes estaría explicada por la incertidumbre propia del mercado y la dificultad de los consumidores para encontrar proveedores de dichos servicios. Margaret F. Bring. nos ilustra con dicha posición:

"Sería de esperar que el mercado elimine a los "corredores" porque no eliminan costos en el sistema. Sin embargo, hay diversas razones para encontrar estos intermediarios en el mercado de subrogación. Dos de esas envuelven los incentivos a la existencia de corredores en el mercado. Primero, la demanda es extremadamente inelástica por el bien en cuestión, los intermediarios extraen el "superávit de consumidores" de una o dos partes de la transacción. Para hacer ello los intermediarios pueden involucrarse en la búsqueda de rentas a través de 
mecanismos públicos o privados. La segunda razón es la inseguridad jurídica con respecto a las madres subrogadas" (F.Brining, 1995, pp. 2394-2395).

Dicha autora afirma que el "creciente número de agencias de subrogación" es causado en razón a que el mercado de maternidad subrogada es un sustituto del mercado de adopción y "dicho mercado es inelástico y restrictivo debido al bajo suministro de bebés causado por la anticoncepción, los abortos selectivos y la creciente relajación del estigma asociado a los solteros en la crianza de hijos, incluida la subvención de la crianza de los hijos solteros a través de la asistencia social" (F.Brining, 1995, p. 2993) y que "los corredores de subrogación no deberían obtener la ganancia de dichos contratos en razón a que pueden actuar para reducir la información entre las partes y aumentan los costos de transacción" (F.Brining, 1995, pp. 2395-2397).

Considero que dicha afirmación no es real, durante una investigación de campo realizada en la ciudad de San Francisco del Estado de California en Estados Unidos se recolectó información de los servicios que brindan dichas agencias ${ }^{1}$ y encontramos que las mismas otorgan al consumidor: (i) un presupuesto detallado de los gastos a incurrir (información vital antes de realizar dicha clase de convenios), (ii) contacto con la madre gestante (iii) contacto con clínicas especializadas en fecundación in vitro (en adelante FIV) y estudios de abogados en maternidad subrogada (iv) contacto seguro de accidentes de FIV, seguro de maternidad para la gestante, seguro del recién nación (v) asistencias psicológicas para la gestante/donante de óvulos (vi) presupuesto de costes variables.

Por otro lado, de lo observado en los medios electrónicos a través de los cuales las madres subrogadas se comunican para realizar sus transacciones, la necesidad de las agencias surge dado que "los padres voluntarios" "desconfían" y prefieren no contratar a madres sin agencias por el temor que la misma se arrepienta, incumpla los cuidados necesarios, etc.

De lo dicho anteriormente, podemos intuir que la posición contra las agencias de maternidad subrogada parte de una posición sesgada por lo que se podría considerar un

${ }^{1}$ Se recolectó información de tres agencias de maternidad subrogada domiciliadas en California a través de llamadas y correos electrónicos, informándoles de la investigación en curso y solicitándoles información detallada de sus servicios. 
“estándar de moral tradicional” ¿Por qué no pueden lucrar las agencias como si fuesen los contratos de corredores tradicionales? Si se encuentran brindando un servicio de conexión de usuarios con proveedores, a la par del asesoramiento legal, médico e incluso el historial de las madres gestantes con las que han trabajado (lo cual es de vital importancia, pues es un contrato donde la experiencia de la madre es un factor fundamental). ¿Por qué no pueden comisionar de dicho servicio-el cual tiene un costo-y brinda seguridad a los usuarios? El argumento de que eleva los costos de transacción entre las partes no resulta válido si lo aplicamos a otro tipo de contratos de corretaje, por lo que resulta un trato diferencial sin explicación razonable. En todo caso, la forma más eficaz de reducir el número de agencias sería crear cierta seguridad en el mercado a través de la legislación, de modo que los agentes no tendrán incentivos para usarlas pues verán el costo alto en relación a su beneficio.

\subsubsection{Macroeconomía}

Como se mencionó anteriormente, la macroeconomía entiende a "la economía como un todo; se focaliza en los estándares de vida de una nación, la cantidad de bienes y servicios que una nación produce en determinada industria" (A. GreenLaw \& Taylor, 2014, pp. 12-15). A través de dicha rama de la economía, buscamos explicar los efectos de dos factores en la industria de la maternidad subrogada: las implicancias de crear límites y las bases a los precios de las mismas y los efectos de una débil institucionalidad en dicha industria.

\subsubsection{Control de los Precios de la maternidad subrogada}

Un recurrente problema social, político, económico e incluso moral en la historia de la humanidad ha sido decidir si amerita ejercer el control de precios en determinados productos. Las razones para optar entre una economía que dirija los precios en contra de una economía de libre mercado pueden ser variadas; en algunos casos se considera justo o necesario para mantener la paz social, como sería el caso del "salario mínimo de los trabajadores" o el "precio de artículos de primera necesidad", en otras obedecen a "motivos políticos como el control de precios máximos de las rentas de San Francisco o Nueva York” (Block, 2002, párr.1). 
La definición exacta de "control de precios" se refiere a las leyes que los gobiernos emiten con la intención de regular los precios de determinados productos. Dichos controles son de dos tipos: "(...) un "precio tope” que mantiene el precio evitando que aumente más allá de cierto nivel y el "precio piso" que mantiene el precio evitando que caiga más allá de determinado nivel (...)” (A. GreenLaw \& Taylor, 2014, p. 65).

En la maternidad subrogada se ha pretendido establecer como solución los dos tipos de control de precios: "el control de precios tope" que sería el caso de la maternidad subrogada de forma altruista, como el "control de precios piso" que sería el caso de exigir un mínimo que deban recibir las madres subrogadas por ejercer su labor.

a. La maternidad subrogada altruista como control de precios tope

La maternidad subrogada altruista es una realidad en países como el Reino Unido (Surrogacy Arrangements Act 1985 , 1985) donde por motivos morales se llega a establecer que el monto que recibirán en compensación las madres gestantes no debe ser suficiente para permitir que lucren con dicha actividad. El problema es que se olvida que dicha medida causara los mismos efectos que el control de precios en cualquier mercado: escasez en la oferta, deterioro del servicio y mercado negro.

El primer gran efecto del control de precios tope es el exceso en la demanda. "En una sociedad, el aumento de los precios controla que el crecimiento excesivo de la demanda. Si dichos precios se mantienen (fijados por ley) y la oferta también, la demanda va a seguir creciendo, creándose un exceso en la demanda y una escasez en la oferta” (A. GreenLaw \& Taylor, 2014, p. 65). Ello, aplicado al mercado de la maternidad subrogada significa que existirán menos madres gestantes dispuestas a dar su vientre y un exceso en la demanda de padres voluntarios que requerirán esos servicios. El siguiente gráfico nos muestra dicho efecto en la economía:

Figuras1-1

"Diagrama del efecto del control de precios tope sobre la curva de oferta y la demanda"

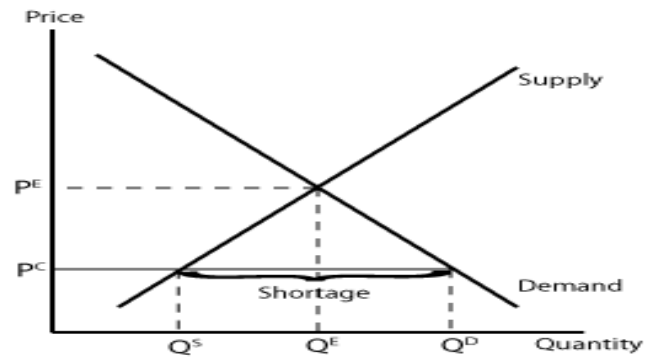


Ilustración obtenida del portal del Centro Experimental de Economía de la Universidad Estatal de Georgia "Andrew Young School” (Experimental Economics Center, 2006), la cual se explica de la siguiente forma:

Siendo que "Pc" es la línea que indica el precio tope y "Pe" el precio de equilibrio. Observamos que al encontrarse "Pc" debajo del precio de "Pe". La oferta "Qs" se mantiene en el punto de equilibrio de "Pc". Sin embargo, la cantidad demandada sigue creciendo hasta "Qd", creándose escasez entre los dos puntos de referencia "Qd" la cantidad demandada y "Qs" la cantidad suministrada.

El segundo gran efecto del control de precios máximo es el deterioro del servicio. Cuando los "precios topes" mantienen los precios bajos para aquellos que demandan el producto, la oferta excede la demanda y la escasez de oferta ocurre. Aquellos que obtienen el producto a un precio menor se ven beneficiados, y aquellos que suministran el producto se ven perjudicados ocasionando que la calidad del servicio se deteriore. "La calidad de un servicio tiene un costo de oportunidad, si los beneficios de asumir ese costo de oportunidad desaparecen, los incentivos para mantener el servicio son menores y este tiende a empeorar" (A. GreenLaw \& Taylor, 2014, p. 66).

En el mercado de la maternidad subrogada, la madre gestante debe asumir una serie de cuidados (costos) como lo serían: una dieta equilibrada, ejercicios especiales o desaparecer malos hábitos, revisiones constantes al médico. Ello con la intención de entregar al niño en las mejores condiciones posibles y recibir un beneficio. Sin embargo, si el beneficio de lucrar se ve reducido, la madre gestante se encontrará dispuesta a asumir menores costos y puede volverse descuidada con la dieta, sus hábitos o incluso priorizar su comodidad a asistir frecuentemente al médico. Ello puede repercutir en la salud del niño y deteriora el servicio otorgado.

Finalmente, quizá el argumento más subestimado contra el uso "precio tope" es la creación de un mercado negro. Al existir escasez de oferta, surgen nuevos proveedores del producto que lo ofrecen a precios más altos de los fijados por ley para suplir el exceso de demanda, pero no a través de los canales de venta oficiales. El ejemplo más claro de la existencia de dicho mercado en razón a la exigencia de un control de precios podemos verlo en los años 80, durante el primer gobierno de Alan García (Izquierdo, 2016, párr.1). Sin embargo, la existencia de un mercado negro ofrece un peligro adicional a solamente 
la venta de dichos productos a un precio mayor que el fijado oficialmente, y este es, la delincuencia con la que se colude para poder usar los canales ilegales de venta.

$\mathrm{Y}$ es que "la existencia del mercado negro (informalidad) y la delincuencia (crimen) han sido objeto de estudio por parte de los economistas durante muchos años" (Huérfano, 2013, párr.1). Sin embargo, sin entrar en las diferentes vertientes que explican dicha correlación, es de recalcar que mientras el mercado negro de drogas trae en conjunto la extorsión y el sicariato. "El mercado negro de la maternidad subrogada tendría efectos similares con la trata de blancas como en México en las zonas menos favorecidas" (MVS Noticias, 2016, párr.1).

Como podemos observar, una política de control de precios tope puede ser ineficiente pues crea un exceso en la demanda y un deterioro en la calidad del servicio. Asimismo, dicha política puede tener un alto costo, como sería el de la creación de un mercado negro que: ofrezca los servicios por encima del precio fijado por ley y la criminalidad que acarre consigo dicho mercado.

b. Precios mínimos en la maternidad subrogada como herramienta para evitar la explotación de la mujer

Se podría sugerir que una solución para evitar la explotación de la mujer gestante en dichos convenios sea exigir un "precio piso" de lo que deben recibir de compensación por sus servicios, algo similar a un salario mínimo de los trabajadores. Bajo el principio descrito anteriormente, los mínimos salariales crean exceso de oferta (como sería el explicado análogamente en un incremento del desempleo debido a un alza en el salario mínimo). Sin embargo, considero que en este punto resulta relevante la elasticidad del mercado de la maternidad subrogada.

La maternidad subrogada se encuadra dentro de lo que los economistas llaman "productos suntuosos", lo que se define como "productos que no son esenciales, pero tienden a incrementar la satisfacción del consumidor. En contraste con los artículos esenciales, los productos suntuosos son usualmente costosos y frecuentemente consumidos por individuos con nivel de ingresos mayor o mayor riqueza acumulada que el promedio" (Business Dictionary, 2018, párr.2). Los productos suntuosos son particularmente sensibles a los cambios en el precio, es decir, son elásticos. 
Por el contrario, los salarios, acorde a la teoría keynesiana, "son rígidos y su demanda responde lentamente a los cambios en los precios" (A. GreenLaw \& Taylor, 2014, pp. 291-292). Sin entrar en mayores detalles, las razones por las que Keynes postulaba la rigidez de los salarios son diversas, entre ellas encontramos: el "argumento de la coordinación" el cual establece que: "los empleadores no tienen un medio de coordinar las reducciones de salarios entre sus trabajadores y el mercado tampoco lo permite, por lo que ante una subida de salarios prefieren reducir otros costos de la empresa" (A. GreenLaw \& Taylor, 2014, p. 291), también los negocios evitan ajustes salariales debido a que reduce la productividad, daña la moral de los trabajadores y finalmente, se dice que ello es debido a la fuerza de los sindicatos y a las trabas legales.

Como podemos observar, tratar al mercado de los salarios como el de los servicios de maternidad subrogada y establecer un mínimo para evitar la explotación de las madres gestante puede tener efecto adverso al esperado, pues el mercado responderá rápidamente a dicho cambio en el precio. Entre las consecuencias posibles encontramos: el crecimiento del mercado informal (donde las madres en estado de necesidad ofrecerán sus servicios por debajo del precio oficial) y la creación de un exceso de oferta en los canales oficiales de contratación.

1.3.3.2 Relación entre institucionalidad e informalidad en el mercado de la maternidad subrogada

Los efectos de la institucionalidad en el desarrollo de un mercado son innegables: "el efectivo cumplimiento de la ley y burocracias eficientes en conjunto con normas adecuadas están fuertemente correlacionados con el mejor desarrollo económico" (Ferrini, 2012). El mercado de la maternidad subrogada no es diferente, una fuerte institucionalidad puede aportar positivamente reduciendo los costos de transacción entre los individuos y reduciendo el riesgo que implican dichos convenios. Por el contrario, "una débil institucionalidad acarrea consigo la informalidad, pues no genera incentivos a los agentes del mercado para trasladarse al marco de ley" (Pérez Billinghurst \& Cornejo, 2015). El modelo económico debe adaptarse al marco institucional del país (contexto social) pues las respuestas de sus agentes económicos son distintas dependiendo del contexto.

Para explicar la hipótesis anterior, primero es necesario definir el concepto de “institucionalidad”, la cual describimos como: “(...) las reglas del juego de la sociedad, 
las limitaciones ideadas humanamente que dan forma a la interacción humana (...) Una estructura de incentivos en el intercambio humano, ya sea político, social o económico (...)" (North, 1991, p. 97). Las instituciones también incluyen, hábitos y creencias, contexto social. Como es conocido, las instituciones pueden reducir los costos de la actividad económica de las siguientes maneras: "reducen los costos de los contratos y incentivan la confianza suministrando políticas adecuadas y sistemas de justicia que otorgan seguridad jurídica” (Ferrini, 2012) Citando a (Coase, 1992.p 197).

Las diferencias en institucionalidad pueden explicar cómo dos países que permiten la maternidad subrogada comercial tengan efectos completamente distintos a nivel social. A modo de ejemplo, tomaré el contexto del mercado de la maternidad subrogada en California, país que actualmente permite la maternidad subrogada, comparándolo con el mercado de maternidad subrogada en la India (PRS Legislative Research, 2018).

En el estado de California "las agencias incluyen sus actividades en conjunto con un equipo de clínicas y abogados, las sentencias de sus tribunales son uniformes, y los acuerdos son notarizados y enviados a la corte superior, proporcionando que dicho estado sea considerado como uno de los destinos más seguros del mundo para realizar dicha clase de convenios” (Ximénes de Sandoval, 2017, párr.1-4).

Por otro lado, en la India se observa la "creación de residencias de madres gestantes donde encontramos mujeres cuyas familias se encuentran en situación de extrema pobreza" (Kapur, 2013) con poca a nula fiscalización estatal. Como evidencia de dicha falta de fiscalización, podemos observar que, "pese a que se prohibió la subrogación a parejas homosexuales en el 2012 en dicho país, los negocios de infertilidad seguían ateniendo a clientes homosexuales provenientes de todo el mundo" (Thapliyal, 2017, párr.3).

Por ello no es de extrañar que el nivel de informalidad entre dichos países también sea muy distinto. Mientras "la India en el 2012 poseía un $86.5 \%$ de su empleo total en situación de informalidad acorde a las estadísticas de la Organización Mundial del Trabajo" (International Labour Organization, 2018) se calcula que "el empleo informal en Estados Unidos se encuentra en un rango de 3\%-40\%" (Smith Nightingale \& A.Wandner, 2011, p. 4). Estas cifras son alarmantes pues nuestro país se encuentra más cercano al primer país, con una estimada "tasa de informalidad en el 2013 de $70.5 \%$ " 
(International Labour Organization, 2018). Con un porcentaje tan grande en la informalidad, es de esperar que las consecuencias sociales sean más parecidas a las de la India que a las del estado de California-Estados Unidos.

Con ocasión de los argumentos expuestos, es razonable pensar que los países de institucionalidad débil sean más propensos a enfrentar consecuencias negativas como las de la India o Tailandia, donde la situación de la mujer se encuentra más cercana a la explotación de sus cuerpos, "los padres voluntarios que conciban niños con enfermedades o discapacitados pueden abandonarlos sin conocimiento de las autoridades" (Redacción BBC Mundo, 2014). Por otro lado, en países con institucionalidad fuerte como en Estados Unidos, el nivel de confianza en las autoridades permite que los agentes del mercado asuman los costos de la legalidad, ya que los consideran una inversión rentable que les otorga seguridad.

Es preciso entender esto, pues los países con débil institucionalidad deberían fortalecer primero la confianza en sus autoridades y normas jurídicas para que la maternidad subrogada permita un eficiente intercambio de recursos. Como en el caso de la India o Tailandia, observamos que una norma clara no es suficiente, es necesario un poder judicial eficiente y una adecuada confianza en las autoridades para que los agentes del mercado asuman el costo de la legalidad. Con los agentes del mercado en el marco legal, los intercambios de recursos serán eficientes y se alcanzará una adecuada distribución de la riqueza.

\subsubsection{Restricciones al turismo reproductivo como barrera a la demanda internacional}

Existen diversos países como Tailandia (BBC Mundo, 2015, párr.4), Grecia (Busardo, Gulino, Napoletano, Zaami, \& Frati, 2014, párr.24) o la India (Panthaky, 2015, párr.1) que han optado por prohibir a las parejas extranjeras buscar a madres sustitutas en sus respectivos países. Las razones para dicho rechazo son básicamente dos; la primera, ocasionada por escándalos como el de la pareja australiana que abandonó a un bebé con síndrome de Down, caso conocido como "Baby Gammy”, se resumen en la frase "existen altos costos en caso los contratos no se ejecuten correctamente" y la segunda, para "evitar que sean explotadas” por extranjeros (The Guardian, 2015, párr.4).

El primer argumento cobra cierto sentido puesto que la maternidad subrogada puede ser considerada un procedimiento con un "alto riesgo social" (término acuñado por 
Bullard, para referirse a actividades que pueden afectar negativamente a la satisfacción social y requiere labor de cuidado por parte del estado) (Bullard, 2009, p. 62) debido a los conflictos que puede causar entre los padres voluntarios y la madre gestante, la responsabilidad de la madre gestante por daños al feto, y la incierta situación del bebé causan que la sociedad sienta aversión ante dichas prácticas y el gobierno buscaría desincentivar dicha práctica.

El segundo argumento no resulta razonable pues los efectos de dicha restricción van a contribuir a empeorar la situación de las madres gestantes. Ello debido a que la apertura al mercado internacional, constituye un incremento en la demanda del servicio. Al cerrar dicho mercado, la demanda va a decrecer y las madres subrogadas pierden poder de negociación por lo que se verán obligadas a disminuir sus precios hasta llegar al nuevo punto de equilibrio.

La siguiente imagen nos describe dichos efectos:

Figuras.1-2

\section{"Diagrama del efecto de control de precios base sobre la curva de oferta $y$ demanda"}

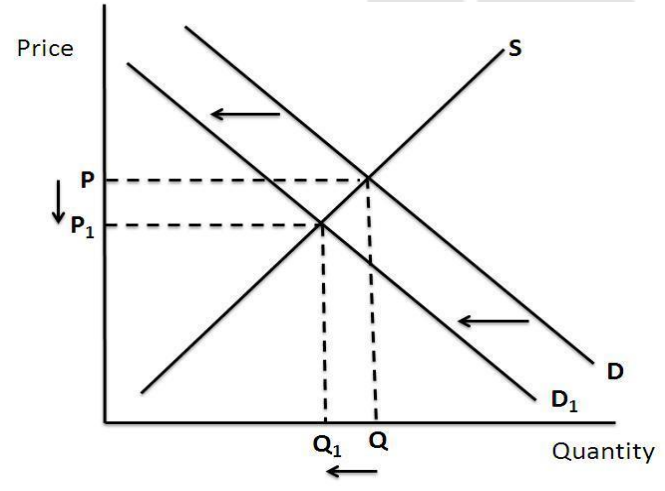

La ilustración obtenida del portal web "Business Investment” (Business 11, 2017) nos muestra una reducción en la cantidad demandada representada por un traslado de la recta D a D1 (cantidad demanda), manteniendo el nivel de oferta y $\mathrm{P}$ (precio) disminuye a P1 para ajustarse al nuevo punto de equilibrio.

Como podemos observar, la prohibición al turismo reproductivo tiene beneficios cuestionables que podrían traducirse en una reducción del riesgo social al desincentivar una actividad que requiere regulación por parte del estado y posee aversión por parte de 
la sociedad, sin embargo, el costo es alto, pues se reduce la demanda y las oportunidades de las madres gestantes para celebrar dicha clase de convenios, obligándolas a reducir sus precios y su poder de negociación.

1.3.3.4 Relación entre las oportunidades de desarrollo económico de la mujer y los precios de la maternidad subrogada

La economía elabora sus modelos basándose en el individuo racional, es decir, aquel que busca maximizar sus beneficios con cada elección que realiza. Ello nos lleva inevitablemente al concepto de "costo de oportunidad", que es "aquello que perdemos para obtener aquello que deseamos. En breve, el costo de oportunidad es el valor de la siguiente mejor alternativa.” (A. GreenLaw \& Taylor, 2014, p. 27). A nivel de macro economía, es lógico pensar que a medida que aumente el costo de oportunidad en las mujeres, es decir, las oportunidades que tengan para desarrollarse en otras actividades que no sean la gestación subrogada, ocurran dos situaciones: la oferta de madres subrogada disminuya o el precio se eleve, de forma que sea más rentable.

A efectos de comprobar dicha hipótesis, elaboré un análisis de regresión lineal con relación variable: "Y" que es la variable dependiente, corresponde a los precios por compensación en maternidad subrogada en dólares estadunidenses y " $\mathrm{X}$ " que es la variable independiente, corresponde al índice de oportunidades económicas de las mujeres. El estudio se encuentra en el "Anexo 1", y la forma de medición que indica de oportunidades económicas de las mujeres se sustenta en un índice elaborado por la unidad de inteligencia de la revista "The Economist" titulado "Women's economic opportunity Index" publicado en el 2012. Dicho índice se apoya en factores como las políticas laborales, prácticas laborales, acceso a financiamiento, estatus social de la mujer, acceso a la educación y el ambiente general de los negocios para elaborar un puntaje que señale las posibilidades de una mujer de desenvolverse económicamente en dicho país. Asimismo, la muestra recogida se basa en 15 países elegidos que gocen de una legislación favorable a la maternidad subrogada ya sea reconociéndola expresamente en la ley o a través de su jurisprudencia. Entre los países que forman parte de dicho análisis encontramos: Estados Unidos, Reino Unido, La India, Ucrania, Tailandia, Canadá, Kenia, Laos, Rusia, Sudáfrica, Grecia, Argentina, Perú, Colombia, Georgia.

En la siguiente ilustración observamos la correlación existente entre dichos puntos: 


\section{Figuras.1-3}

"Mapa de correlación y tendencias entre la Oportunidad Económica de la Mujer y Precio de compensación"

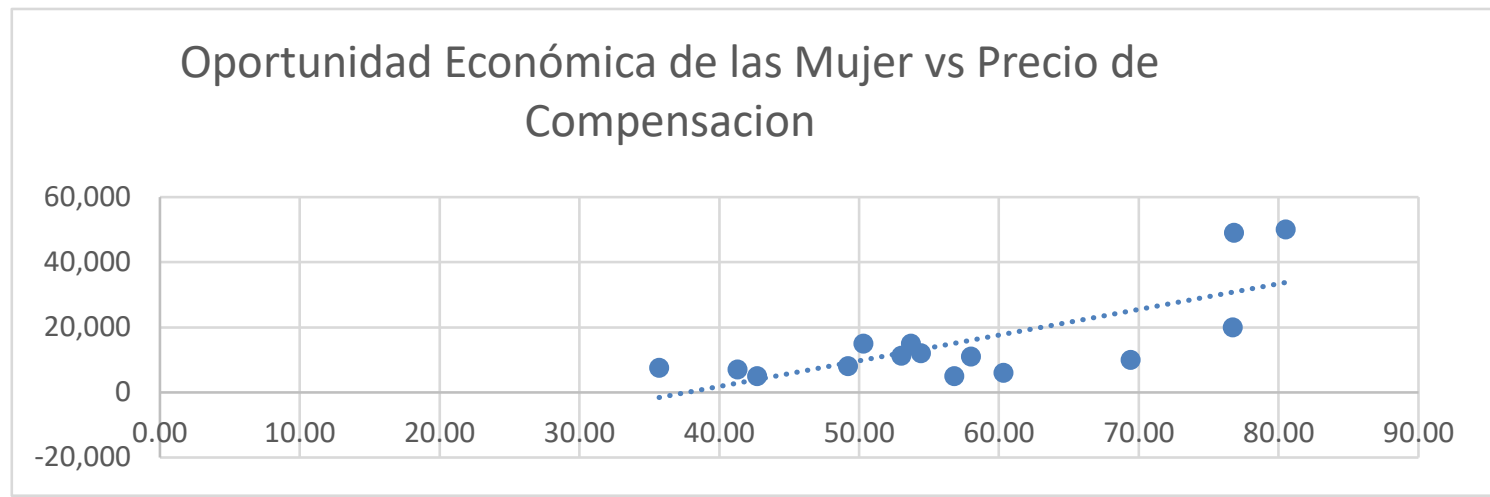

Asimismo, en un análisis de correlación elaborado a través de la función "data análisis" de la aplicación Excel encontramos que la ratio de correlación entre las variables es aproximadamente de "0.7362”, lo que en el común de las estadísticas se entiende una correlación "muy fuerte" al ser mayor a 0.6. Adicionalmente, en el análisis de regresión lineal nos muestra un "r elevado al cuadrado modificado" de " 0.5420 " lo que se traduce en un 54\% de la variación en los datos es explicada como una correlación entre $\mathrm{X}$ e $\mathrm{Y}$. Finalmente un valor de $\mathrm{P}$ de " 0.00175 ", menos a 0.05 , lo que resulta suficiente para descartar la hipótesis nula (es decir, la hipótesis que niega una correlación entre las variables $\mathrm{X}$ e $\mathrm{Y})$.

En razón a ello, se afirma que existe una fuerte correlación entre el precio de la compensación por alquiler de vientre y el costo de oportunidad de las mujeres, lo que nos permite declarar válida la siguiente hipótesis: A mayor capacidad de las mujeres de desarrollarse económicamente, mayores serán los precios de las madres subrogada debido a un incremento en el costo de oportunidad. 


\section{CAPÍTULO II: ANÁLISIS ECONÓMICO DE LEGISLACIÓN COMPARADA EN LA MATERNIDAD SUBROGADA}

De acuerdo a lo explicado en el capítulo anterior, la maternidad subrogada estudiada a través de las herramientas del AED se ha focalizado en el análisis de nivel microeconómico, descartando el contexto en el cual deben emitirse las normas y, por ende, ocasionando que sus consecuencias y proyecciones no sean aplicables a todos los mercados. En el presente capítulo, se realizará el análisis macroeconómico en diversos países elegidos en base a sus diferentes contextos sociales y regulaciones de dicha materia con el objetivo de brindar un marco de referencia más amplio de cómo interactúan dichas normas en su contexto social.

\subsection{Metodología del Estudio}

El siguiente análisis combinará un estudio bibliográfico y de campo-cualitativo realizado a través de información obtenida vía correo electrónico con los proveedores del servicio y observando su comportamiento a través de medios electrónicos por los cuales realizan sus transacciones. Dicho método, si bien se encuentra sujeto a la subjetividad del informante, es eficaz para aproximarse a fenómenos sociales pues permite adentrarse en la intimidad y percepción de la realidad del usuario.

Dicho método, en conjunto con la intensa revisión bibliográfica de la legislación de cada país, nos permitirá teorizar de cómo funcionan dichas normas y qué efecto han causado en los agentes del mercado.

Para el análisis de mercado nos valdremos de una versión modificada del esquema “Cinco Fuerzas de Porter", el cual reconoce cinco fuerzas fundamentales para la descripción de una industria: “(i) la rivalidad de una industria (que se refiere a la cantidad de proveedores existentes y su poder en el mercado), (ii) la amenaza de entrada de nuevos competidores (iii) la amenaza de que los consumidores opten por productos sustitutos (iv) el poder de negociación de los proveedores (que se refiere a la capacidad de los 
proveedores para determinar el precio) (v) el poder de negociación de los consumidores (que se refiere a la capacidad de los consumidores para determinar el precio)" (Team Management Ebooks, 2013). Considerando que dicho análisis tiene sus carencias, añadiremos el factor (iv) "factores externos" que incluirá todos los elementos del “análisis PESTLE (nombre que proviene de las siglas en inglés de los factores políticos, económicos, sociales, medioambientales, tecnológicos y legales)" (UCF Libraries, 2018) y eliminaremos el factor (ii) "entrada de nuevos competidores" del esquema de Porter pues no estamos analizando el mercado a nivel de empresa, sino a nivel de industria. Cabe recalcar que, si bien dichos esquemas son útiles para aproximarse a la realidad, es posible que sean considerados subjetivos dado que algunos factores se interrelacionan y mucha información se encuentra oculta.

\subsection{Análisis económico y legal de la maternidad subrogada en el estado de California (Estados Unidos)}

La legislación de Estados Unidos no es uniforme en relación con el tratamiento de la maternidad subrogada, la mayoría de estados la prohíben, siendo que los pocos estados que la permiten, son considerados uno de los mejores destinos a nivel mundial para realizar dichos tratamientos, a pesar que el precio triplica al de los países asiáticos donde dichos convenios también son legales.

La autora Rocío Ruiz Martínez, nos explica en modo breve, las diferencias en las legislaciones de cada estado, mencionando a California como un estado permisivo con dichas transacciones y donde más centros y agencias "brindan corretaje" para dichos arreglos:

“En 1987 surgieron proyectos de Ley en casi todos los Estados, aunque tan solo Arkansas (su específica normativa prevé si una pareja contrata a una madre subrogada soltera, ellos son los padres legales del niño), Nevada (la ley exige la prohibición de pago que rige para la adopción) y Lousiana (no son exigibles los contratos de maternidad subrogada), tenían ya leyes aprobadas. De los proyectos de ley que existen, cinco pretenden su prohibición (Alabama, Illinois, Iowa, Maryland y Wisconsin) y otros siete intentan prohibir la llevada a cabo de modo comercial y lucrativo. (Florida, Kentucky, Michigan, New Jersey, New York, Oregón y Pensilvania). Y muchos de los Estados que lo permiten la delimitan a una inmensa regulación: California e Illinois detallan que la compensación económica debe ser razonable, permitiéndose la reducción judicial 
si fuera excesiva. Florida, Illinois, Carolina del Sur, Jersey, exigen estar casados a los futuros padres. Estos dos últimos estados, establecen una investigación sobre la vida y el entorno familiar, social, aptitudes, circunstancias morales, disposición, capacidad de los futuros padres, etcétera. (..) En proporción a su extensión, California es el estado norteamericano con más centros que anuncian estos "arreglos" y agencias que actúan de intermediarias. Por este motivo, el Comité de Ética del Colegio Americano de Obstetricia y Ginecología ha elaborado las responsabilidades éticas del profesional que participe en el proceso de subrogación destacándose el asesoramiento de los comitentes, el acompañamiento potencial a las gestantes proveyéndolas de los servicios necesarios y los aspectos, médicos, éticos, legales y psicológicos asociados” (Ruiz, 2013, pp. 21-22)

Como podemos observar, el hecho que California sea el estado que más centros posee que anuncian estos arreglos y actúan de intermediarios constituye una fuerte razón para convertirlo en un objeto de estudio. Además, entendiendo que California es un estado con fuerte institucionalidad, permitiendo que, en la práctica, dicha clase de convenios que se celebren de forma comercial, dicho estado será el primero a ser analizado en su contexto social y legislación.

\subsubsection{Análisis del marco legal en el estado de California}

La legislación en California es bastante clara con relación al tratamiento de la maternidad subrogada, la misma que está reconocida por la "Ley de paternidad uniforme" (en inglés “Uniform Parentage Act”), documento aprobado en 1973 por la "Comisión Nacional de leyes uniformes del estado", que consiste en un intento por unificar la ley de paternidad en Estados Unidos. "Dicha ley fue adoptada por California en 1975 e incorporada en la sección 7600 et. seq. del código de familia de California" (H.Schawartz, 2016, pp. 1-2).

Asimismo, el 23 de septiembre del 2012, California incorporó a la sección 7960 del código de familia de California, el proyecto "AB1217" (conocido como "Assembly Bill'). De la información de la ley obtenida de la página web oficial del gobierno de California (California Legislative Information, 2017), podemos observar que la misma se pronuncia sobre los siguientes puntos considerados relevantes:

En la sección 7961 se regula los contratos que son realizados por personas que no son "abogados" (el inciso (d) de la sección 1960 define que un convenio realizado por un 
no abogado incluye a toda persona que practica la subrogación o la donación y que no tiene licencia para practicar la ley en ese estado).

"Los acuerdos realizados por un "no abogado" que practica la subrogación o facilite la donación, se encuentran obligados a indicar al cliente que deposite los pagos por el servicio (denominados "fondos" por la ley y descritos como "compensación por los servicios") en un fideicomiso que sea independiente del "no abogado" que custodia el dinero." (AB-1217, 2012)

En la sección 7962 se menciona la información que el convenio de gestación subrogada deberá contener, aclarando que es lo requerido, pero no una limitante a la información que puede ir en el convenio. Entre los puntos relevantes encontramos:

“(a) Deberá contener información de las personas donde los gametos se originaron, a menos que se usen gametos donados. En cuyo caso basta con que se especifique que son donados.

(b) La identidad de los padres voluntarios (o padres previstos según la denominación de la norma)

(c) Divulgación de cómo los padres cubrirán los gastos médicos. Cobertura de atención médica (seguro), incluido cualquier gasto médico que pudiese ser originado del embarazo sustituto, y la divulgación de las disposiciones de la póliza de atención médica en relación con la responsabilidad de la madre sustituta.

(d) Las partes en el contrato de subrogación deberán notarializar sus firmas.

(e) Las acciones para establecer relación los padres o padre previsto y el niño puede presentarse antes del nacimiento.

(f) El acuerdo notarizado de reproducción asistida debe ser firmado en conjunto con las declaraciones adjuntas de dos abogados independientes y presentado al tribunal superior, el cual refutara las presunciones de paternidad gestacional.

(g) El acuerdo, consentimiento, renuncia enviado al tribunal no podrá ser fiscalizado por ninguna agencia de investigación (en estados unidos las agencias de investigación pueden ser cualquier órgano de alguna entidad estatal), o cualquier apoderado y dichos archivos no se encontrarán abiertos a inspección. Un juez superior no autorizara a nadie inspeccionar dichos documentos salvo en circunstancias excepcionales y cuando sea necesario.

(h) El acuerdo de reproducción asistida para madres subrogadas se presume válido y no podrá ser rescindido ni revocado sin una orden judicial. Y a efectos de esta parte, cualquier 
incumplimiento de los requisitos deberá refutar la presunción de validez del acuerdo de reproducción asistida para portadores gestacionales.” (AB-1217 , 2012)

No obstante, dicha ley solo ha sido una consecuencia que busca regular los procedimientos que las numerosas y uniformes sentencias han reconocido previamente. Entre los primeros casos que se reconocen dichos convenios encontramos el afamado “caso Anna Jonhson contra Mark Calvert”, llevado a la Corte Suprema de California:

"Los hechos de dicho caso se desenvolvieron de la siguiente manera: Mark y Crispina Calvert eran una pareja que decidieron tener un niño, pero Crispina llevó a cabo un procedimiento de histerectomía (extracción de útero) en 1984. En 1990, Mark y Crispina suscriben con Anna un contrato de maternidad subrogada, siendo que la pareja proveía un embrión (con gametos de la pareja) que sería implantado en el de Anna dando a luz a un niño que sería asumido como el hijo de Mark y Crispina. Anna renunciaba a todos los derechos de parentalidad a favor de la pareja. Sin embargo, las relaciones entre ambos se deterioraron, la pareja alegó que Anna había ocultado que había tenido abortos y Anna argumentó que la pareja no había obtenido la póliza de seguro requerida. En 1990, Anna envió una carta a la pareja demandando el balance de pagos o renunciaría a entregar al niño. Ante ello, la pareja respondió con una demanda de paternidad que se consolidó con otra acción de Anna para que ella misma sea declarada como madre. En 1990, como consecuencia de la prueba de sangre que ella misma proveyó, se determinaba que Anna era la madre.

A pesar de ello, en el juicio de 1990, la corte determinó que Mark y Crispina eran los "padres genéticos, biológicos y naturales" y que Anna no tendría derecho alguno sobre el niño. Además, que el contrato de subrogación era legal y obligatorio contra los reclamos de Anna, sin embargo, se determinó un régimen de visitas para Anna.

Anna apeló dicho fallo argumentando que las políticas que subyacen a las leyes de adopción son violadas por el contrato de maternidad subrogada, porque constituye una renuncia previa al nacimiento a sus derechos parentales. La corte suprema determinó en segunda instancia, que la maternidad subrogada difiere de la adopción y por ende no es aplicable una analogía. Asimismo, se afirmó que no era vulnerable a incentivos financieros para separarse de su propia descendencia y los pagos estaban destinados a compensarla por sus servicios en la gestación del feto y del parto.

Asimismo, se pronunció sobre la creencia que el contrato de subrogación puede entrar en conflicto con las prohibiciones de servidumbre involuntaria (esclavitud) al prohibirle abortar. 
Sin embargo, las leyes de estados unidos permiten que la mujer aborte y toda promesa en contrario es inaplicable, por lo que no afecta la validez del contrato.

Finalmente, se pronunció sobre uno de los argumentos sugeridos por la escuela del AED, el que afirma que la mujer gestante carecía de conocimiento e inteligencia para consentir el embarazarse de un bebé y entregarlo a los padres previstos. La corte explicó que no era serio argumentar que una madre que fuese enfermera licenciada y que hubiese dado a luz a un niño previamente no tuviese la experiencia de vida necesaria para tomar una decisión informada para suscribir el contrato" (Johnson v. Calvert, 1993).

Como se observa, la condición de la madre fue analizada para determinar si poseía la capacidad para otorgar consentimiento informado de dicha decisión. Adicionalmente, se determina que no contaba con algún incentivo financiero, $\mathrm{y}$, por ende, no era contradictorio con las leyes de adopción. Sin embargo, dicho enunciado no debe ser interpretado como una prohibición a la maternidad subrogada comercial, pues la sentencia y la ley del estado admiten la compensación monetaria "aunque limitadas por razonabilidad".

Por otro lado, la jurisprudencia también ha reconocido los convenios de subrogación en parejas gay. En el caso conocido como K.M vs E.G:

"Una pareja de lesbianas que no lograron concebir por medio de un proceso de fecundación artificial, decide usar los óvulos de K.M a efectos de embarazar a E.G. Además, E.G declaró que ella aceptó esto entendiendo que ella sería la madre única que criaría al niño y figuraría en el certificado de nacimiento. A pesar de la relación genética con K.M, E.G hizo prometer a K.M que no revelaría que los óvulos donados eran de ella. Por el contrario, K.M afirmó que ella solo aceptó donar los óvulos basándose en el entendimiento que las mujeres criarían al niño como pareja. Las mujeres ofrecieron diferentes informes, entre ellos, un documento firmado por K.M renunciando a los derechos parentales.

Los gemelos nacieron de E.G a fines de 1995 y solo Lisa figuró como madre en sus certificados de nacimiento. Las mujeres criaron juntas a los gemelos hasta que su relación terminó a principios del 2001, cuando K.M demandó a E.G para obtener una declaración de derechos parentales. La corte desestimó su demanda, declarando que K.M había aceptado solo ser una donante de gametos y que la paternidad le correspondía a E.G” (K.M v. E.G, 2005) 
Por último, en el caso Kristine H. v. Lisa R.:

"Una pareja lesbiana fue sometida a inseminación artificial. Una vez nacido el hijo, se solicitó que la corte declare la paternidad de la pareja. La pareja se separó años después y Kristine demandó a Lisa para declarar su estatus parental y evitar que ella tenga algún derecho de custodia o de visita. En agosto del 2006, la corte suprema de california ordenó que Kristine no podía desafiar la orden anterior de la corte y que ambas mujeres eran padres legales, reconociendo el estatus de madre no biológica de Lisa" (Kristine H. v. Lisa R., 2005).

De estas últimas sentencias, observamos que el estado de California ha reconocido expresamente a las parejas homosexuales y los hijos que conciban o tengan las mismas producto de un procedimiento de procreación asistida. En ese sentido, priorizará la voluntad de los mismos al momento de someterse a dichos procedimientos, haciendo que "la voluntad" prevalezca sobre otros hechos como que puedan considerarse razón de filiación como "la convivencia".

\subsubsection{Análisis del mercado e impacto en el estado de California}

A efectos de brindar un análisis general del mercado de California, y basándonos en el esquema explicado anteriormente, esquematizaremos de la siguiente forma la situación de la industria de maternidad subrogada en dicho estado:

(i) La rivalidad de la industria

El estado de California es considerado "uno de los destinos más requeridos para realizar dicha clase de prácticas, tanto a nivel de Estados unidos como del mundo" (Ximénes de Sandoval, 2017, párr.1). Existen estimaciones de que Estados Unidos sería el "segundo destino a nivel del mundo para realizar dichos convenios, luego de la India y el rango de consumidores extranjeros varia del 40\%-50\%" (Sloan, 2017, párr.4) siendo que otros afirman podría ser de 70\% (Ximenes de Sandoval, 2017, párr.5). De los datos obtenidos a través de comunicaciones electrónicas con "Northwest Surrogacy Center", alrededor del $45 \%$ de las familias que atendieron en el 2017 provienen de Estados Unidos, 28\% de Europa, 23\% de Asia (Northwest Surrogacy Center LLC, 2017, p. 2). 
Es considerado como un "destino recomendado por la seguridad jurídica que brindan sus convenios, además de la calidad de la atención médica” (Babygest, 2018, párr.5).

Por otro lado, la información recopilada a través de las aplicaciones electrónicas nos permite identificar al menos 18 agencias de subrogación con sede en el estado de California. Cabe recalcar, que este solo es un dato indiciario pues la maternidad subrogada básicamente posee 3 canales de distribución; directo de madres gestantes a padres previstos o voluntarios, las agencias de maternidad subrogada y las clínicas de reproducción asistida. Por dichas razones la rivalidad en la industria de la maternidad subrogada puede ser considerada alta, lo que crea un efecto positivo para el intercambio de recursos.

(ii) La amenaza de productos sustitutos

La adopción sería el producto sustituto más cercano al de la maternidad subrogada, por lo que lo más lógico sería analizar su precio y su situación en Estados Unidos. Sin embargo, entendiendo que California es considerado como uno de los destinos de turismo reproductivo, su efecto se vería distorsionado pues los consumidores extranjeros podrían optar por el mercado de adopción en sus países de origen.

Los costos de la adopción en Estados Unidos ascienden en promedio a un rango de "8,000 a 40,000 dólares para los residentes y dependiendo del canal por el que se lleve a cabo el proceso (agencia de adopción o de forma independiente)" (American Adoptions, 2018). Sin embargo, la adopción de niños en Estados Unidos parece ser un mercado particularmente inelástico y restrictivo, con una demanda que supera ampliamente a la oferta. De acuerdo a las estimaciones del 'Comité Nacional de Adopción’ de los Estados Unidos, "los procesos de adopción son declinados en un $38 \%$ debido principalmente a tres factores: disminución de los niños disponibles en adopción, mayor cantidad de abortos, mejor uso de los anticonceptivos y reducción del estigma social de ser padres solteros" (Lindsay, 1987, p. 001001). Ello perjudica la situación de los consumidores provenientes de Estados Unidos, en lugar que los consumidores del extranjero.

(iii) El poder de negociación de los consumidores

De la información obtenida en vía web y en contacto con tres agencias de subrogación, observamos que los procedimientos de alquiler de vientre suelen cotizarse 
en un rango de 90,000 a 150,000 dólares en California, de los cuales en un rango de 39,000 a 42,000 dólares son considerados “compensación por la maternidad”. Por ello, los consumidores de dicho mercado tienen que gozar de un alto poder adquisitivo.

Asimismo, podemos entender que, al ser extranjeros, tienen acceso al mercado mundial por lo que tienen la posibilidad de optar por otros países en caso no encuentren la oferta deseada. Sin embargo, su objetivo es la seguridad jurídica que otorga Estados Unidos con relación a dicho mercado, por lo que se encuentran dispuestos a pagar un precio que se cotiza por encima del mercado internacional. Dado su poder adquisitivo y su acceso al mercado mundial, los consumidores suelen tener un alto poder de negociación pues tienen capacidad para rechazar el contrato y buscar mejores ofertas en otros países o el mundo.

(iv) El poder de negociación de los proveedores

Las madres gestantes pueden garantizar la seguridad jurídica en razón a la legislación favorable en dicho país y al nivel de intervención estatal en dichos procedimientos, lo que mejora su situación permitiéndoles elevar sus precios. Asimismo, existe una alta demanda de sus servicios, al ser California un centro mundial de turismo reproductivo, por lo que sus precios se encuentran por encima del mercado. Dada la seguridad jurídica que brindan, la alta demanda, y el restrictivo mercado sustituto (adopción) considero que los proveedores (madres gestantes) gozan de un alto poder de negociación.

Asimismo, uno de los factores que determina el precio de la subrogación es el costo de oportunidad de las mujeres en dicho país, por lo que a efectos de aproximar el costo de oportunidad me apoyaré en el reporte de The Economist "Women's economic opportunity" y el "Índice" para medir las oportunidades laborales y de emprendimiento de las mujeres en el mundo.

De la revisión de dicho documento, encontramos que "Estados Unidos se encuentra en el puesto número 15 en el mundo con un puntaje de 76.7" (Economist Intelligence Unit, 2012, p. 7), razón por la cual entendemos que Estados Unidos es un país que presenta oportunidades a las mujeres para desarrollarse en diferentes sectores, lo que, al otorgarle más opciones rentables, aumenta su costo de oportunidad y por ende, afecta positivamente a una alza en el precio. 
(v) Los factores externos

Como fue explicado anteriormente, la reciente prohibición de maternidad subrogada a extranjeros en Tailandia y la India ha trasladado la demanda internacional a otros destinos. Sin embargo, acorde a datos recopilados personalmente a través de correo electrónico con "Worldfertilityservices", la demanda se trasladaría a países como "Laos" y "Kenia" con legislaciones permisivas o no reguladas. Cabe recalcar, que países como Tailandia eran considerados destinos reproductivos al no contar con ley de la materia, por lo que podemos inferir que los consumidores de dichos convenios en dicho país tenían menor aversión al riesgo (acepten menor seguridad jurídica) y menor poder adquisitivo. Al poseer Estados Unidos un precio elevado sobre el nivel internacional, podemos entender que dichos consumidores propensos al riesgo y con menor poder adquisitivo se trasladen a otros destinos.

En conclusión, la conjunción de los siguientes factores: la legislación permisiva, la demanda internacional, el mercado restrictivo de adopción, el alto poder adquisitivo de los consumidores y las oportunidades de desarrollo económico que el país otorga a las mujeres, ha permitido que el mercado en Estados Unidos resulte simétrico pues los consumidores y proveedores gozan de un alto poder de negociación. Asimismo, el gran número de agencias que facilitan dichos convenios incrementa dichas transacciones al otorgar mayores facilidades, contacto, garantías por lo que el mercado se desarrolla sin obstrucciones (reducen el riesgo de los consumidores). La alta demanda, sumada al alto costo de oportunidad de las mujeres, permite una eficiente asignación de recursos y, por ende, un nivel más alto de satisfacción en dicho tipo de convenios.

\subsection{Análisis económico y legal de la maternidad subrogada en la India}

La India es considerado el "más grande destino del turismo reproductivo en el mundo" (Bindel, 2016), sin embargo, la visión occidental del desarrollo de dichas técnicas en ese país siempre ha sido muy crítica con relación a sus beneficios. Es común el uso de denominaciones como "granjas humanas" o "granjas de bebés" (Velasco Hdez, 2015) para describir a las residencias que resguardan madres de alquiler en dicho país. En razón a ello, y siendo que la India constituye un país con un desarrollo económico acelerado, una institucionalidad que está fortaleciéndose a pesar de poseer altos índices de 
informalidad similares a los de Perú, será el siguiente país a ser analizado en su contexto social y legislación.

\subsubsection{Análisis del marco legal en la India}

Los convenios de maternidad subrogada en la India se convirtieron en una práctica legal en el 2002 gracias a la publicación de lineamientos de prácticas éticas en tratamientos biomédicos. Dichos lineamientos, elaborados por el "Consejo indio de investigación médica" (ICMR por sus siglas en inglés), regulan dichas prácticas en su capítulo 3 inciso 10. Titulado “Consideraciones Generales de la Subrogación” de la siguiente forma:

“(a) El niño debe ser adoptado por los padres genéticos a menos que se pueda establecer una filiación genética a través de las huellas dactilares (cuyos récords deben ser mantenidos en la clínica) que el niño es de ellos.

(b) Solo se llevará a acabo de la subrogación cuando sea imposible físicamente para la pareja prevista llevar un bebé en el vientre.

(c) Los gastos de la madre subrogada deben estar cubiertos, el centro de técnicas de reproducción asistida no debe tener ningún interés monetario en el convenio.

(d) El límite de edad para ser madre subrogada es de 45 años.

(e) Una persona conocida, un familiar o una desconocida pueden ser madres subrogadas, pero en el caso del familiar, deben pertenecer a la misma generación que la madre sustituta.

(f) Ninguna mujer debe ser madre subrogada más de tres veces." (Indian Council of Medical Research, 2002)

Cabe recalcar que dicho documento, si bien no es "propiamente una ley" es elaborado por una entidad fundada por el gobierno de la India, a través del departamento de investigación médica en el Ministerio de salud y bienestar familiar.

Adicionalmente, la legalidad de dichas prácticas se reforzó posteriormente con el famoso caso "Baby Manji vs Union of India”. Dicho caso involucró, "a una pareja japonesa que encargó a una madre sustituta en la India, pero terminaron en un divorcio. Al padre soltero no se le otorgó la custodia del niño y la madre se negó a aceptarlo. El estado del Japón otorgó al niño visa humanitaria y le permitió a la abuela llevarse al niño en nombre de su hijo, dada su relación genética con el bebé. Durante el caso, sin embargo, el Tribunal Supremo reconoció que el padre de un hijo sustituto puede ser un hombre y 
la maternidad sustituta reconocida como una práctica positiva" (Pandey\&Associates Advocates, 2017, párr.4).

Entre los puntos destacables en la sentencia, recalco (Baby Manji Yamada vs Union Of India, 2008):

(a) Se reconoce expresamente la legalidad de la "subrogación comercial" como una forma de subrogación en la que se paga a la portadora gestacional para llevar a un niño hasta la madurez en su útero, distinguiéndola de la "subrogación altruista" (también una práctica legal) donde la madre sustituta no espera ninguna recompensa financiera.

(b) Se reconoce que los padres previstos pueden ser solteros o una pareja homosexual.

(c) Se permite a las parejas realizar dichos acuerdos con y sin apoyo de las agencias de maternidad subrogada.

Sin embargo, en los últimos años a raíz del caso del "Bebé Grammy" (The Guardian, 2015), la India ha optado por cerrar las puertas a la subrogación. Y si bien, aun no se ha aprobado ninguna norma, existe un proyecto en curso y "las comunicaciones del gobierno a la Corte Suprema que no respaldarán la subrogación comercial ni la subrogación en extranjeros" (Tarishi, 2017). Asimismo, "buscarán que se limite para casos donde sea estrictamente necesario" (Grupo de redacción de The Indian Express News, 2017).

El proyecto de ley No. 257-2016, creado el 21 de noviembre del 2016 e introducido al parlamento llamado "Lok Sabha" el 10 de agosto del 2017 contempla los siguientes aspectos relevantes:

“(a) Los procedimientos de subrogación serán realizados solo en parejas infértiles.

(b) Se prohíbe la publicidad, el inducir a las mujeres a subrogarse, promover la subrogación.

(c) Ninguna clínica, medico, ginecólogo, embriólogo, parejas prevista u otras personas guardarán embriones para la subrogación.

(d) Solo se permitirá la subrogación de forma altruista.

(e) Se prohíbe a toda persona tomar un procedimiento de subrogación bajo clínicas que no estén registradas bajo esta ley. 
(f) Se creará una junta nacional de subrogación para revisar la implementación de la ley, las regulaciones que deban realizarse y otorguen recomendaciones al gobierno central.

(g) Se sancionará penalmente (con pena privativa de la libertad) a los corredores de subrogación, aquellos que abandonen o exploten niños nacidos a través de subrogación, que exploten a una madre subrogada, que vendan gametos o embriones con propósitos de subrogación.

(h) Se sancionará con una multa a aquellos que realicen publicidad con relación a la maternidad subrogada.

(i) Solo mujeres casadas que tengan niños propios y edad entre 25 y 35 años al día de la implantación, pueden ser madres subrogadas.

(j) La pareja prevista debe estar casada al menos 5 años y ser ciudadanos indios" (PRS Legislative Research, 2018).

Como podemos observar, si bien la legislación actual contempla la maternidad subrogada comercial y realizada por extranjeros, existe una fuerte tendencia judicial y política a revertir dicha situación. Probablemente, en los próximos años la legislación será mucho más restrictiva, estableciendo barreras para el registro de las clínicas, prohibiendo la venta del material genético, prohibiendo el corretaje de maternidad subrogada y causando el desmantelamiento de la industria.

\subsubsection{Análisis del mercado e impacto en la India}

El mercado de maternidad subrogada en la India se presenta bajo un esquema más complejo que el de California por los radicales cambios que ha contemplado su legislación en los últimos años. En el siguiente esquema se buscará otorgar un acercamiento a los cambios en el tiempo en la industria:

(i) La rivalidad de la industria

La India ha logrado crear un parámetro muy cercano al "libre mercado de alquiler de vientres", su normativa permisiva y sus altos índices de informalidad han permitido la creación de agencias de maternidad subrogada que funcionan al mismo tiempo como "residencias de madres gestantes" donde se vigila o cuida a las madres que se dedican a dicha labor. La socióloga Amrita Pande en su libro "Wombs in Labor" Transnational 
Commercial Surrogacy in india" nos brinda su conclusión respecto a un estudio especializado del mercado en dicho país:

"La estructura india se encuentra cercana a un modelo liberal de libre mercado y las clínicas siguen sus propias reglas informales. Las clínicas en la India, no solo operan sin interferencia del estado sino también se benefician del apoyo que el estado les brinda a los turistas reproductivos. En el 2004 el gobierno lanzó una campaña de publicidad declarando legal dichos tratamientos en extranjeros e incentivando que traigan sus ganancias" (Pande, 2014, p. 13).

Asimismo, en una revisión rápida a las aplicaciones electrónicas podemos observar 14 centros dedicados exclusivamente a la subrogación situados en Nueva Delhi, dato indiciario del tamaño de la industria, pues descarta las transacciones realizadas en clínicas, los tratos directos entre partes y las agencias informales. Asimismo, de las conversaciones con un corredor de subrogación vía correo electrónico, se observó que se ofrecía este servicio en diversas clínicas de New Delhi, Mumbai, Bangladesh y Hyderabad, por lo que podemos asumir que el número supera ampliamente el observable a través de la aplicación.

Estas últimas, se suelen encontrar más alejadas de la capital en poblaciones rurales (Ashok, 2016) y contribuyen de forma drástica al incremento de la competitividad en dicha industria. Se estiman un aproximadamente 350 clínicas o centros de "maternidad subrogada" en la India - y una industria que mueve unos 2000 millones de dólares al año (Thériault \& Palacio, 2012, párr. 26).

(ii) La amenaza de productos sustitutos

La adopción es un problema complejo en la India pues resalta los aspectos más crudos de dicha sociedad. Si bien "los costos de adopción son relativamente bajos en comparación con otros países pues se calcula un rango de 12,000 a 15,000 dólares" (Aarefa, 2015, párr.1), existen trabas burocráticas y sociales que impiden que dicho mercado se desarrolle. El primer problema existente es el de la corrupción pues "es usual que se exijan montos desde 300 hasta 500 dólares en sobornos que son exigidos por parte de los funcionarios para permitir la adopción" (Aarefa, 2015, párr. 15). También existe el problema social de "las castas", pues gran parte de la población considera tabú el “adoptar niños de otras castas". 
Ello, "sumado a los 3 años en promedio de duración de un proceso de adopción han creado una oferta que supera ampliamente la demanda, contando con un estimado de alrededor de 30 millones de huérfanos en el país en el 2014, de los cuales se adoptaron 2500 en el 2013" (Lakshmi, 2015, párr.3). Rama Lakshmi en su artículo "India moves to improve 'shameful' record on orphan adoptions" reconoce que las trabas legales causan que la mayoría opte por la maternidad subrogada o el soborno a los oficiales a efectos de evitar las frustrantes colas que presenta dicho servicio en el país.

En razón a los factores expuestos anteriormente, el mercado de adopción en la India impone costos de transacción altos ligados a la corrupción, tabús sociales y barreras burocráticas, lo que ha trasladado la demanda de niños a la subrogación.

(iii) El poder de negociación de los consumidores

Los consumidores gozan de un poder adquisitivo alto pues como fue mencionado anteriormente, el vientre de alquiler puede ser considerado un producto "suntuoso" por su precio. No obstante, de lo conversado vía correo electrónico con agencias de subrogación en la India y de los recursos obtenidos internet, cotizamos que el rango de precio de la compensación suele encontrarse alrededor de 5,000 a 15,000 dólares y las agencias suelen cobrar los mismos montos por contactar con las madres subrogadas.

Por otro lado, con la reciente prohibición, existe la posibilidad que la mayoría de consumidores extranjeros se hayan trasladado a países del sur asiático o África como Laos o Kenia que son considerados como "estados amigables a la subrogación", en lugar de optar por la informalidad. Por lo que, al reducirse la demanda, los consumidores del mercado indio se ven beneficiados. Finalmente, el hecho que el gobierno no legitime la subrogación comercial, otorga una ventaja adicional al momento de determinar el precio. Por estas razones, considero que el actual consumidor en dicho país goza de un poder negocial casi absoluto.

(iv) El poder de negociación de los proveedores

Al haber sido la India un mercado internacional de subrogación, la alta demanda de extranjeros y la seguridad jurídica de su jurisprudencia permitían a las madres gestantes la determinación de precios satisfactorios, a pesar que el perfil de muchas de ellas es de mujeres en situación de pobreza (Pande, 2014, p. 15) y provenientes de zonas rurales, sin estudios y considerando a la subrogación como "la única alternativa para 
hacer dinero" (Kapur, 2013). Sin embargo, debido al comunicado del gobierno a prohibir la subrogación en extranjero y de las propias averiguaciones realizadas vía correo electrónico con corredores en la India encontramos que dicho procedimiento sólo se estaría brindaría a ciudadanos indios. Ello sin duda afectaría drásticamente el poder de negociación de los proveedores limitando el ofrecimiento de su producto a la demanda local o a la informalidad (la cual involucra que se entregue en adopción al niño gestado a los extranjeros y aumenta los costos).

Asimismo, el índice de oportunidades económicas de las mujeres en la India es de los más bajos en el mundo, encontrándose en el puesto 84 con un puntaje de 42.7 (Economist Intelligence Unit, 2012, p. 7). Por lo que el costo de oportunidad de las mujeres es muy bajo, reduciendo a la vez sus precios.

En ese sentido, el poder de negociación de las madres gestantes se ha visto disminuido por el reciente cambio social-político y combinando la disminución de la demanda, la situación de pobreza en la que se encontraban y la inseguridad jurídica, parecen encontrarse en una situación de asimetría favoreciendo la aparición de explotación. Sin embargo, de las entrevistas realizadas en el documental de CNN observamos que el dinero obtenido por las madres gestantes es usado para financiar la educación de sus hijos, su alimentación y mejorar su estatus de vida por lo que la asimetría trae consigo una mejoría del estatus de vida (Kapur, 2013).

(v) Los factores externos

Dentro de los factores externos, encontramos la ya mencionada antes, prohibición por el gobierno al turismo reproductivo internacional que reduce la demanda y encoge el mercado a consumidores locales. Asimismo, la alta informalidad y corrupción en los sistemas de adopción restringe las opciones y permite los convenios "comerciales" pese a que la ley detalla no debe existir incentivos económicos en dichos convenios.

En conclusión, si bien la industria de la maternidad subrogada en la India gozaba hasta hace unos años de un ambiente cercano a la libre competencia, la reducción en la demanda internacional sumada a la exigencia a evitar el lucro con dichos convenios afectará drásticamente a las madres gestantes, acentuando la asimetría que existía entre ellas y los consumidores, impidiéndoles alcanzar precios satisfactorios. 


\subsection{Análisis económico y legal de la maternidad subrogada en el Reino Unido}

El Reino Unido no es considerado un destino de turismo reproductivo pese a que la maternidad subrogada es legal en dicho país desde 1985. Ello puede deberse a que sus leyes permiten que el acuerdo sólo sea llevado de forma altruista y cualquier medida de publicidad o promoción a dichos procedimientos sea considerada un delito. Asimismo, las madres gestantes gozan de la capacidad de revocar dichos acuerdos y la paternidad del niño les pertenece desde que nace hasta hacer la entrega a los padres previstos. Adicionalmente, a raíz del caso "Re Z" resuelto en el 2016, el gobierno ha comunicado al parlamento que se prevé un cambio en la legislación para eliminar la discriminación hacia los padres solteros (NGA Law, 2017, párr.11).

Los hechos expuestos nos llevan a pensar que el estado ha buscado reconocer dicha clase de acuerdos de forma conservadora sin incentivar el surgimiento de industria fuerte como en la India y todo reconocimiento de derechos se estaría dando a paso lento. Por estas razones, consideramos que el Reino Unido nos podrá dar una visión más amplia de una legislación permisiva cuya orientación eliminaría las principales críticas a dichos procedimientos: el argumento de la venta de niños y la explotación de la mujer.

\subsubsection{Análisis del marco legal en el Reino Unido}

El Reino Unido regula la maternidad a través de la "Ley de contratos de subrogación de 1985", norma que surgió a raíz del caso "Baby Cotton” y la "Ley de Fertilización Humana y Embriología de 1990" que mantiene a los acuerdos como no obligatorios pero validables posteriormente al parto

La primera norma, la "Ley de subrogación de 1985", presenta los siguientes puntos relevantes:

“(a) Ninguna persona debe incentivar las negociaciones, ni tomar parte de las negociaciones, ni ofrecerse a negociar un acuerdo de maternidad subrogada comercial. Dicha conducta será considerada un delito.

(b) Solo se realizarán acuerdos de maternidad subrogada sin ánimo de lucro. El pago debe ser razonable.

(c) Está permitido que un organismo facilite la contratación de maternidad subrogada sin fines de lucro. 
(d) En los procedimientos en contra de la acusada de haber cometido el delito descrito en el inciso (a), se asumirá que la persona no realizó subrogación comercial si recibió el pago antes de realizar dicho procedimiento.

(e) Se prohíbe la publicidad de maternidad subrogada a excepción que sea para una agencia sin fines de lucro" (National Archives, 2018).

Asimismo, la segunda norma llamada la "ley de fertilización humana y embriología de 1990" comprende las siguientes indicaciones:

“(a) Reconoce la subrogación a través de las "órdenes parentales”. Estas consisten en órdenes emitidas por la corte para que el niño sea tratado como el niño de los aplicantes a la orden. La ley afirma que las órdenes pueden ser solicitadas a pesar que el niño haya sido gestado por otra mujer que no sea ninguno de los aplicantes como resultado de haber depositado un embrión en la mujer gestante o haber sido inseminada artificialmente.

(b) Los aplicantes deben ser casados (marido y mujer), compañeros civiles o dos personas que viven como pareja en una relación familiar que no tengan impedimento para estar en una relación.

(c) La orden puede ser solicitada recién a los 6 meses de nacido el niño.

(d) La entrega de la orden debe ser libre e incondicional (no debe mediar contrato)" (NGA Law, 2017)

A pesar que los convenios de maternidad subrogada no son obligatorios por ley, existe el precedente de dicho país que probaría lo contrario. El caso conocido como "Baby Cotton" en el cual una pareja gay celebró un contrato de maternidad subrogada con una mujer identificada como "S". La mujer "S" fue inseminada artificialmente y la orden parental seria otorgada a favor de "B" (parte de la pareja gay). No obstante, la madre no se desentendería completamente del niño pues tendría derecho a "visitas" y a "mantener contacto con él." Posteriormente la madre se arrepintió de la entrega y trato de incumplir el contrato, sin embargo, la corte la obligó a entregar el bebé a la pareja (Gayle, 2015, párr.1).

Entre los fundamentos, se entendió que, "si bien los contratos de maternidad subrogada no son obligatorios en el Reino Unido, "la madre había mostrado una conducta agresiva y prejuiciosa contra la pareja gay, causando que la corte optara porque el niño 
se quedase con la pareja prevista fundamentando en que era lo mejor para el interés del niño" (Baby Cotton, 2015, inc. 51).

En conclusión, si bien el Reino Unido cuenta con una norma que regula la maternidad subrogada, dichos convenios no son ejecutables y la paternidad del niño se otorga después del nacimiento a través del procedimiento de la "orden parental", en el cual la madre es libre de otorgar o no la paternidad según considere conveniente. Sin embargo, la jurisprudencia ha reconocido que el niño puede quedarse con la pareja prevista en contra de los deseos de la madre si esta se encuentra justificada en un bien mayor el "contrato", como es el caso del "mejor interés del niño".

\subsubsection{Análisis del mercado e impacto en el Reino Unido}

El Reino Unido, a diferencia de los últimos dos países, no es caracterizado por ser un destino mundial de turismo reproductivo pese a que su legislación permite la maternidad subrogada. En el siguiente esquema, podremos observar los factores que contribuyen a dicha situación:

(i) La rivalidad de la industria

El Reino Unido muestra la existencia de diversas agencias que promueven la subrogación, de las cuales observamos 15 agencias dedicadas a realizar dichos procedimientos a través de las aplicaciones electrónicas repartidas homogéneamente por todo el país. Sin embargo, "existen indicios que la demanda de los ciudadanos británicos se estaría trasladando al extranjero, particularmente a Ucrania o la India posiblemente debido a los precios más accesibles” (Ponniah, 2018, párr.7) y "evitar la incertidumbre con relación a la entrega del hijo en dichos contratos" (Taneja, 2011, párr.18). Ante ello, podemos encontrar que la industria es altamente competitiva, siendo que el mercado internacional ha desplazado al local.

(ii) La amenaza de productos sustitutos

La adopción en el Reino Unido, al igual que los países estudiados anteriormente, presenta un mercado restringido, en este caso por las barreras burocráticas establecidas. De acuerdo a las estadísticas del departamento de educación, "el número de niños adoptados en el 2011 era 5\% menor al del año pasado y 20\% menor al del 2005”. Las 
razones que explicarían el fenómeno de la reducida adopción en el Reino Unido es el tiempo de espera promedio para ser adoptado (2.7 años) y los rigurosos procesos de selección. De acuerdo a Jonathan Pearce, director de "Adoption UK" confirma que "la existencia de una escasez en las personas que buscan adopción y que, combinado con otras barreras y demoras, muchos niños son dejados de lado" (Curtis, 2011, párr.2). En ese sentido, podemos observar que, a pesar de la poca demanda local de maternidad subrogada, el mercado de adopción resulta poco atractivo, lo que permite la existencia de un pequeño nicho para la maternidad subrogada local.

(iii) El poder de negociación de los consumidores

El mercado de subrogación en el Reino Unido posee dos desventajas básicas que explican el desplazamiento de la demanda al mercado internacional: (i) la paternidad del hijo pertenece a la madre gestante, la misma que es entregada luego del parto a través de las órdenes parentales y (ii) sus precios, si bien son menores a los de Estados Unidos, no logran ser compensados por una reducción en el riesgo, por lo que existen mercados más atractivos con igual riesgo y menor precio.

La abogada de fertilidad Natalie Gamble, declaró ante "The Telegraph" que

“(...) las compensaciones por maternidad subrogada en dicho país suelen encontrarse alrededor de 20,000 dólares. El precio si bien se encuentra limitado por la jurisprudencia a "gastos razonables", no establece un monto fijo. No obstante, "existe el peligro que la corte considere el monto pagado al momento de otorgar la paternidad legal y lo reduzca” Natalie Gamble entrevistada por (Muffit, 2015, párr.1).

Conscientes de dicha problemática, los "montos adicionales por compensación" "suelen otorgarse bajo la figura de regalos, que son difíciles de rastrear y desestimar, como pagar un seguro de salud o automóviles”. (Mowbray, 2017, párr. 4). En razón a lo mencionado anteriormente, podemos inferir que el precio suele estar por encima del "monto razonable" descrito, sin embargo, no provee la misma seguridad jurídica que California, razón por la cual la demanda se traslada al extranjero.

Empero, el trasladarse al extranjero a realizar dichos procedimientos también se incluye un riesgo pues ante cualquier evento negativo, es más difícil y costoso defender los derechos civiles en un país diferente al de origen. Por ello, es que el mercado no es 
casi inexistente, el consumidor prefiere enfrentar cualquier eventualidad bajo sus cortes nacionales.

(iv) El poder de negociación de los proveedores

Los proveedores enfrentan a un mercado internacional bastante competitivo cuyos principales oponentes suelen ser Ucrania y Georgia, países que han declarado legal la maternidad subrogada y por la cercanía suelen trasladar la demanda de la mayoría del mercado europeo. Por otro lado, en menor medida "compiten con Vietnam, Laos, Kenia o Nigeria que se encuentran desregulados, pero permiten obtener precios más bajos" (Mowbray, 2017, párr.6). La disminución de la demanda se puede observar comparativamente, donde a diferencia de California y Estados Unidos "donde la subrogación internacional suele rondar el 50\% o $70 \%$ de la demanda del mercado, los nacimientos de subrogación internacional en el Reino Unido se estiman en un promedio de 13.64\% del total de dicho país del 2011 al 2015" (Horsey, Smith, Norcross, Ghevaert, \& Jones, 2015, p. 14).

Asimismo, de un estudio publicado por Cafcass, la agencia responsable de reportar a la corte respecto a las aplicaciones de órdenes parentales, ha detectado que los procedimientos por "subrogación internacional en el Reino Unido se encuentran en incremento gradual y sostenido desde 2,25\% en el 2003 a 36,58\% en el 2013" (Horsey, Smith, Norcross, Ghevaert, \& Jones, 2015, p. 15), por lo que la demanda que opta por realizar los procedimientos en el extranjero sigue en incremento, restándole poder negociación a las madres gestantes en del mercado local.

Por otro lado, el costo de oportunidad de las mujeres es bastante alto, lo que incrementa su poder de negociación. El índice de oportunidades económicas para las mujeres en el Reino Unido se encuentra con un puntaje mayor al de Estados Unidos, en “el puesto 14 con 76.8 de puntaje" (Economist Intelligence Unit, 2012, p. 7). Lo que equilibra el traslado de la demanda, evitando que los precios bajen al nivel de los países del sur-oeste asiático.

(v) Los factores externos

Entre los factores externos que más han influido en la maternidad subrogada en el Reino Unido es la "legalización de los procedimientos en Ucrania" (Mowbray, 2017, párr.2) y el "cierre de subrogación a los extranjeros en la India" (Sherwell, 2015) los 
cuales no parecen haber traído la demanda al mercado local, sino trasladarla a otros mercados internacionales más atractivos.

En conclusión, si bien la demanda de maternidad subrogada en el Reino Unido se ve reducida por mercados internacionales con ofertas más atractivas que las locales ya que ofrecen el mismo riesgo a menor precio. La situación económica favorable para las mujeres les permite tener más opciones, por lo que sus precios si bien son más bajos que en Estados Unidos, son más altos que los de países donde las mujeres tienen menores oportunidades.

\subsection{Análisis económico y legal de la maternidad subrogada en España}

Entre las principales ventajas de elegir a España como objeto de estudio, encontramos que posee una "legislación muy similar a la nuestra" (Guzmán, 2001, p. 547). Ello no solo se basa en que muchas instituciones nuestras del Código Civil tienen inspiración en su legislación, sino también por la historia compartida que tenemos, siendo que Perú ha sido colonia española y, por ende, hemos asimilado gran parte de su cultura. Por otro lado, es importante recalcar que España cuenta con legislación de técnicas de reproducción asistida desde 1988 donde expresamente reconoce la prohibición a dicho tipo de procedimientos, por lo que nos brindará un espectro más preciso de los efectos de no reconocer expresamente dichos convenios. Finalmente, España presenta un panorama interesante pues a pesar de su legislación adversa, se celebran ferias de gestación subrogada que generan tensión entre algunos grupos sociales activos, particularmente en grupos feministas (que son especialmente fuertes en España) y la Iglesia, por lo que el surgimiento del mercado en condiciones adversas es un fenómeno que no debe pasar desapercibido.

\subsubsection{Análisis del marco legal en España}

La regulación en España de maternidad subrogada se basa en la "Ley 35-1988 sobre técnicas de reproducción asistida" que data del 22 de noviembre de 1988 y es expresa con la prohibición de dichos convenios en el país. La mención breve de esta ley se resume en los siguientes puntos detallados en su artículo 10: 
“(a) Será nulo de pleno derecho el contrato por el que se convenga la gestación, con o sin precio, a cargo de una mujer que renuncia a la filiación materna en favor del contratante o de un tercero.

(b) La filiación de los hijos nacidos por gestación de sustitución será determinada por el parto.

(c) Queda a salvo la posible acción de reclamación de la paternidad respecto del padre biológico" (Ley de técnicas de reproducción Asistida, 1998).

No obstante, los pronunciamientos administrativos españoles habían reconocido a los hijos producto de dichos convenios realizados en el extranjero. Entre ellas contamos con la Instrucción de la Dirección General de los Registros del Notariado (en adelante DGRN) (Instrucción del 7 de Octubre del 2010 DGRN, 2010) y la Resolución Judicial (RJ 2009/1735, 2009).

La instrucción del DGRN precisaba lo siguiente:

"DGRN exige que de existir una resolución judicial extranjera que acredite la filiación de un menor nacido tras una gestación por sustitución en filiación con el padre biológico, la misma puede someterse a exequatur en España (importante recalcar que dice resolución judicial y no simple constancia de registro)" (Calvo Caravaca \& Carracosa Gonzáles, 2011, p. 249).

Mientras que la resolución 2009/1735:

“(...) acordó la inscripción de dos certificados de nacimiento emitidos en California, que declaraban la filiación paterna de dos hombres españoles casados entre ellos, respecto de unos gemelos gestados a partir del recurso a la Gestación Subrogada y nacidos en octubre de 2008. Basándose en el artículo 17 del C.C. Siendo que padre o madre eran españoles (...)” (Casado, 2017, p. 206).

Sin embargo, las cosas tomaron un giro drástico con la resolución del Tribunal Supremo de España (Casación STS 247/2014, 2014) que "acordó dejar sin efecto la inscripción de dos menores nacidos en el Estado de California, por gestación por sustitución, ello a pesar que contaban con certificaciones registrales extranjeras en las que figuraban como padres dos varones españoles casados entre sí”. 
Por otro lado, la jurisprudencia internacional europea parecía ser favorable a dichos convenios. El 27 de enero del 2015 la Segunda sección de Corte Europa de Derechos Humanos (en adelante $\mathrm{CEDH}$ ) dictó una reconocida jurisprudencia conocida como "Paradiso \& Campanelli vs Italia" favorable al reconocimiento internacional de estos convenios, el caso versaba sobre:

"Una pareja italiana que, al no poder concebir, obtuvo la licencia para adoptar a un niño extranjero y decidió realizar un procedimiento de maternidad subrogada en Moscú. Con papeles fraudulentos los padres voluntarios intentaron ingresar al niño a Italia, pero las autoridades no lo permitieron, sometieron a la pareja a pruebas de ADN y determinaron que niño estaba en estado de abandono al no tener vínculo con los padres y que fuese enviado a una casa hogar. La pareja llevó el caso ante la CEDH la cual fundamentó en base (i) al mejor interés del niño y (ii) que de facto había existido una relación familiar que permitía reconocer la filiación basándose en el artículo 8 Convenio Europeo de Derechos Humanos (en adelante CNEDH" (Paradiso\&Campa nelli vs Italy, 2015).

A pesar de ello, en un reciente fallo del 2017 de la Gran Sala de la Corte Europea de Derechos Humanos (la instancia superior en el mismo caso) se consideró una posición totalmente adversa a la instancia anterior, basados en los siguientes motivos:

"La decisión de los tribunales italianos de quitar la tenencia de un niño a quienes celebraron un contrato de maternidad subrogada y no poseen vínculo biológico con el niño no constituye una violación del art. 8 (respeto a la vida privada y familiar) de la Convención Europea de Derechos Humanos pues esta no garantiza a adoptar. Asimismo, afirmó que la relación con el niño había sido muy corta para establecer algún vínculo familiar" (Paradiso\&Campanelli vs Italy, 2017)

En resumidas cuentas, la jurisprudencia y la legislación española han cambiado radicalmente su orientación en los últimos años y han sido particularmente firmes tratando los casos de maternidad subrogada, cerrando las aberturas para sentar un precedente que reconozca dichos convenios o permita que dichas técnicas se realicen en el país. Asimismo, la tendencia internacional parece otorgar mayor autonomía a los estados para regular dicha materia, por lo que es posible que incluso peligre el turismo reproductivo. Dada la novedad de las sentencias y en rangos tan altos como casación 
resulta poco creíble que el panorama se encuentre próximo a cambiar en los siguientes años.

\subsubsection{Análisis del mercado e impacto en España}

La legislación y jurisprudencia española prohíben expresamente la maternidad subrogada, por lo que por definición estaremos hablando de un "mercado negro". Ello elimina a la informalidad como riesgo y lo convierte en la situación general, lo que nos acerca a la realidad peruana. En las siguientes líneas, esquematizaré el mercado de maternidad subrogada de la siguiente manera:

(i) La rivalidad de la industria

España presenta una prohibición expresa y poco atractiva, por lo que la industria de maternidad subrogada es de tamaño muy reducida. Basándonos en la información obtenida de las aplicaciones electrónicas, podemos observar solo 3 centros que ofrecen facilitar dicho tipo de contratos, de las cuales todas son clínicas de fertilidad y no se observa ninguna agencia dedicada exclusivamente al "corretaje" en España. Por otro lado, "existen algunas agencias que contactan con clínicas en el extranjero principalmente California o países de Europa del este como Rusia o Ucrania” (Larrañeta, 2014).

(ii) La amenaza de productos sustitutos

Como podemos observar, el registro notarial prohíbe que se reconozca la paternidad de los padres previstos nacidos en España. Asimismo, existen sentencias de casación donde no se reconoce la paternidad de hijos de subrogación nacidos en un país donde esta se encuentra permitida, por lo que el riesgo de que el único camino para reconocer a un hijo producto de estos procedimientos sea la adopción es alto. El único beneficio que otorga la maternidad subrogada es el material genético de los padres previstos, pues los costes del reconocimiento de paternidad incluyen el procedimiento de adopción.

Por otro lado, España parecía contar con una alta demanda de adopción, siendo que en el 2005 dicho país fue considerado como el primer país en la Unión Europea y el tercero en el mundo que más adopciones realizaba, con un $80 \%$ de adopción internacional (Grupo de redaccion de "El mundo", 2005, párr.4). No obstante, en los datos actuales se 
calcula que la adopción internacional ha caído un 85\% en los últimos 10 años (Borja, 2017, párr.1). De lo revisado en distintas páginas web, "el costo de adopción nacional en España puede cotizarse en un rango de 14,000 a 20,000 euros y el tiempo medio es de 5 años" (M. J García, 2016, párr.1) existiendo una alta demanda que incrementa gradualmente en las adopciones nacionales y disminuye en las internacionales.

Es necesario recalcar que en los últimos años se menciona un aumento en la maternidad subrogada en España debido al incremento de barreras de la adopción internacional. Se afirma que "adopción internacional ha caído $60 \%$ en los últimos 3 años debido a que países como Rusia no permiten adoptar a la gente soltera o homosexuales, lo que impulsaría a las familias hacia la gestación subrogada que es más rápida y sencilla" (EFE Agencia, 2017, párr.1-4)

(iii) El poder de negociación de los consumidores

Parece ser que la prohibición en "España traslada la mayor cantidad de la demanda al extranjero, principalmente Estados Unidos y países de Europa del este" (Altarriba, 2017), y en menor medida al Reino Unido o Latinoamérica. La expresa prohibición y el impedimento de inscripción del hijo nos impiden contar de datos oficiales, pero "se estima que la mayoría realiza dichos procedimientos en el extranjero" (Enfoque Televisión, 2014). Al ser trasladada la mayor cantidad de demanda al extranjero, los que realicen dichos procedimientos en el mercado negro español, deben realizarlo a muy bajo costo pues el costo de adopción y el alto riesgo hacen muy poco atractivo el mercado.

(iv) El poder de negociación de los proveedores

Las madres subrogadas del mercado negro español no presentan ventaja alguna respecto al mercado internacional. No obstante, en concordancia con el índice de oportunidades económicas para las mujeres, "España se ubica en el puesto 26, con un puntaje de 70.5 7" (Economist Intelligence Unit, 2012, p. 7), lo que nos permite afirmar que existen actividades lucrativas para las mujeres y el costo de oportunidad es alto, lo que les da mayor poder de negociación.

(v) Los factores externos

España parece enfrentar unas "dos fuerzas poderosas que empujan hacia la legalización de la subrogación: la ralentización de la adopción, el matrimonio homosexual" (Larrañeta, 2014). Sin embargo, las ferias internacionales de subrogación 
parecen generar tensión entre grupos particularmente activos políticamente, por lo que es común que se realicen marchas en contra la subrogación impulsadas por grupos feministas que gozan de especial fuerza en dicho país (Urra, 2017). Por ello, el contexto social crea un importante desincentivo para el surgimiento de un mercado viable.

En conclusión, la prohibición expresa de maternidad subrogada en España en conjunto con las altas oportunidades para que las mujeres se desarrollen económicamente en otros ámbitos permite que la demanda de dichos procedimientos de traslade al extranjero. Asimismo, al ser una actividad que genera tensión social y sufrir fallos jurisprudenciales contradictorios en altas instancias, los incentivos para la formación de una industria son muy bajos. Por otro lado, una reciente tendencia a incrementar las trabas para la adopción en Rusia estaría retornando la demanda al mercado de la maternidad subrogada Español por ser este un método más rápido y accesible.

\subsection{Análisis económico y legal de la maternidad subrogada en Argentina}

La elección de Argentina como objeto de estudio se basa principalmente en la similitud tanto legal como social que compartimos con dicho país. Un análisis de dicho país nos puede brindar un mejor alcance de los efectos de una legislación "silenciosa" en materia de maternidad subrogada, pues la misma no ha sido mencionada en la "ley 26.862" (Ley Nacional de Fertilización Asistida, 2013). A pesar de ello, cabe recalcar que reciente jurisprudencia ha optado por reconocer dicho tipo de contratos por lo que el panorama de dicho mercado puede encontrarse próximo a cambiar. Por las razones mencionadas anteriormente, Argentina es un objeto de estudio viable para este ensayo.

\subsubsection{Análisis del marco legal en Argentina}

Si bien, la ley 26.862 que regula las técnicas de reproducción asistida en dicho país, así como el Código Civil y Comercial han optado por el silencio absoluto en dicha materia, existen fallos judiciales son favorables a los mismos. Sin embargo, no todo es uniforme pues también existe un sector de la doctrina que considera los mismos como ilegales.

Dicha tendencia doctrinaria que asume que dichos convenios se encuentran prohibidos por el Código Civil Comercial "al prohibir la entrega de niños "mediante 
escritura pública o acto administrativo" (Centro de Bioética, 2018, párr.6) fundamentándose en el artículo 611 del nuevo Código Civil y Comercial de dicho país, el cual nos dice:

"Guarda de hecho. Prohibición. Queda prohibida expresamente la entrega directa en guarda de niños, niñas y adolescentes mediante escritura pública o acto administrativo, así como la entrega directa en guarda otorgada por cualquiera de los progenitores u otros familiares del niño. La transgresión de la prohibición habilita al juez a separar al niño transitoria o definitivamente de su pretenso guardador, excepto que se compruebe judicialmente que la elección de los progenitores se funda en la existencia de un vínculo de parentesco, entre éstos y el o los pretensos guardadores del niño. Ni la guarda de hecho, ni los supuestos de guarda judicial o delegación del ejercicio de la responsabilidad parental deben ser considerados a los fines de la adopción" (Centro de Bioética, 2018, párr.6).

Dicha posición entiende que el prohibir la entrega de niños mediante escritura pública o acto administrativo salvo que tengan vinculo de parentesco, implica una prohibición expresa a la maternidad subrogada.

Por otro lado, entre la jurisprudencia contamos con una reciente sentencia de expediente $\mathrm{N}^{\circ} 714 / 15 / 1 \mathrm{~F}$ del 29 de julio del 2015 producto de un proceso de "acción declarativa de filiación" llevado a cabo en el primer juzgado de familia de la provincia de Mendoza, Argentina, en la cual se reconoce expresamente la legalidad de dichos contratos. Entre los fundamentos de aquella decisión recalcamos

“(a) La maternidad subrogada no pacta la entrega de un hijo propio dado que el niño no guarda ningún vínculo biológico con ella, en dicho convenio la madre "cede temporalmente su útero" para que sea implantado un embrión.

(b) Se refiere al dinero recibido como "remuneración del servicio de gestación" diciendo que prefiere dicho término al de compensación o indemnización.

(c) Afirma que dicho contrato es jurídicamente valido dado que, si bien el cuerpo humano está fuera del comercio, dicho acto no constituye un acto de disposición del cuerpo humano, sino la cesión temporal del cuerpo en razón del servicio de gestación.” (O.A.V., G.A.C. \& F.J.J., 2015) 
Ello resulta coherente con un fallo anterior, el expediente 38316/2012, de fecha 18 de junio del 2013, el cual reconoce la inscripción de una niña nacida por gestación subrogada bajo los siguientes fundamentos:

“(a) "La voluntad procreacional”, es decir, la intención de engendrar un hijo con material biológico propio, acudiendo a la portación del embrión en el vientre de un tercero para su gestación y alumbramiento posterior es el elemento determinante de la filiación.

(b) No importa que la gestante se encuentre casada o unida de hecho, no existirá filiación a dicho matrimonio" (N. N. o D. G. M. B. M. s/ inscripción de nacimiento, 2013)

Con dichos fallos, podemos observar que, si bien la legislación no se ha pronunciado al respecto, la jurisprudencia argentina si lo ha hecho, lo que agregaría cierta predictibilidad a la situación de la maternidad subrogada en dicho país. Asimismo, existe un proyecto de ley S-2574/15 (Centro de Derecho y Religión, 2018) que busca permitir dichos convenios bajo autorización judicial previa, crear un registro de madres gestantes, y sancionar penalmente a aquellos médicos que realicen transferencias embrionarias sin autorización judicial. Sin embargo, este no sería el primer proyecto rechazado debido a la fuerte tendencia conservadora en el país, por lo que la situación de la legislación en los siguientes años resulta incierta.

\subsubsection{Análisis del mercado e impacto en Argentina}

El potencial de Argentina como destino reproductivo radica en los precios bajos y la calidad de sus tratamientos médicos. De acuerdo a los estudios, "la mayoría del turismo reproductivo en Argentina proviene de un sector acomodado de Norteamérica o Europa que buscan evitar las largas colas de espera, altos precios, ausencia de técnicas de reproducción asistida en sus países" (Smith, Behrmann, Martin, \& Williams-Jones, 2010, págs. 3-4). El mercado de maternidad subrogada en Argentina se esquematizará de la siguiente forma:

(i) La rivalidad de la industria

Resulta complicada la medición del tamaño de la industria dado que existe poca información oficial respecto a la maternidad subrogada. Por el contrario, podemos lograr 
un estimado basado en el "boom del turismo reproductivo" que enfrenta actualmente (Lahrichi, 2016). Asimismo, de la búsqueda de internet vemos que existió una agencia autodenominada como la primera agencia de maternidad subrogada "Maternity Argentina", sin embargo, "dicha agencia fue cerrada en el 2015 debido a denuncias por trata de blancas y haber permitido la salida irregular de bebés del país” (Mannino, 2015) a pesar que "la empresa se defendió afirmando que solo asesoraba legalmente a las parejas que no podían concebir” (Antún, 2015).

Ello nos da una idea que el "corretaje" de maternidad subrogado es una actividad de alto riesgo pese a que la demanda es alta pues puede ser ligada a delitos de trata de blancas y causar un alto costo a las partes involucradas. Por otro lado, el boom de las clínicas reproductivas trae consigo esta práctica de forma oculta, por lo que entendemos que la rivalidad de la industria es alta.

(ii) La amenaza de productos sustitutos

La situación de la adopción en Argentina parece estar mejorando gradualmente. De acuerdo al último estudio elaborado por la Secretaria de Niñez, adolescencia y familia y Unicef en 2015, cada vez hay menos chicos viviendo en una institución al cuidado del Estado: son 9219 niños y adolescentes en esa situación, un 37\% menos que en 2012. (Urdinez, 2017, párr.5). Si bien no se exigen costos, los plazos pueden variar entre 2 a 5 años en Buenos Aires, dependiendo de las ciudades y la demanda. (Infobae, 2013).

(iii) El poder de negociación de los consumidores

Debido a la alta demanda internacional de dichos tratamientos reproductivos y recolectando datos de páginas web y redes sociales, observamos que "el rango de precios (compensación) en Argentina varía entre 8,000-14,000 dólares" (Babygest, 2018), sin embargo, es importante decir que no existe un rango estimado por lo cual es posible encontrar precios fuera de dicho rango. Igual, siendo que el boom reproductivo es lo que impulsa dicho mercado, hablamos de consumidores con capacidad de escoger otros mercados, por lo que gozan de poder de negociación.

Por otro lado, en concordancia con la Revista online "Babygest" de gestación subrogada, "a pesar de las sentencias donde se reconoce la maternidad subrogada en los padres previstos o voluntarios, existen probabilidades que un juez de primera instancia 
declare la paternidad de la madre gestante" (Babygest, 2018),, por lo que el riesgo a tener que afrontar un sobrecosto (proceso judicial o proceso de adopción) es alto.

(iv) El poder de negociación de los proveedores

Las madres gestantes se ven beneficiadas por la alta demanda proveniente del extranjero siendo que sus precios son un poco mayores que los de la India. Por otra parte, las oportunidades económicas de las mujeres en dicho país alcanzan un nivel intermedio a nivel global, ubicándose en el "puesto número 47 de 113 países, por encima de Perú con un puntaje de 58. 7" (Economist Intelligence Unit, 2012, p. 7) Ello nos permite entender que gozan de oportunidades para desarrollarse, lo que aumenta su costo de oportunidad y poder de negociación.

(v) Los factores externos

Debido al cierre de la subrogación internacional en la India, "la demanda local de vientres de alquiler se encuentra aumentando gradualmente debido a los altos costos de realizarlo en países como California o Ucrania” (Reina, 2012, párr.13). No obstante, existe una "fuerte presión de la Iglesia que empuja hacia la desregulación" (Reina, 2012, párr. 22), y el ambiente político se encuentra dividido, por lo que existe mucha inseguridad con relación a los fallos judiciales y el peligro de caer en la interpretación de tráfico de niños.

En resumen, la maternidad subrogada en Argentina se ve impulsada por los fallos judiciales favorables, los bajos costos de los tratamientos médicos y de compensación de gestantes. Empero, la actividad aún causa tensiones sociales y políticas, por lo que el mercado goza de un riesgo intermedio que no le permite alcanzar a las madres gestantes el nivel de satisfacción que podrían alcanzar en un mercado con reglas claras. 


\section{CAPÍTULO III: ANÁLISIS ECONÓMICO APLICABLE A UN MARCO LEGAL DE LA MATERNIDAD SUBROGADA EN EL PERÚ}

De acuerdo a lo observado en el capítulo anterior, factores como el contexto socialpolítico, las oportunidades económicas de la mujer y la seguridad jurídica influyen en el precio de los servicios de subrogación, y, por ende, en el nivel de satisfacción que las partes pueden alcanzar en dichos convenios. En el presente capitulo, se aplicarán los factores influyentes en dicho mercado a un marco legal en nuestro país para predecir y teorizar un marco legal que permitan un intercambio económico en nuestro en el Perú

\subsection{Análisis económico legal de la maternidad subrogada en el Perú}

El Perú goza de potencial para ser un destino de turismo reproductivo dados los bajos costos de procedimientos de fertilidad en comparación con los otros mercados y su ausencia de regulación en materia de maternidad subrogada. Si bien, la legislación establece que "la condición de la madre gestante y madre genética debe recaer en la misma persona" (Ley General de Salud, 1997), lo cierto es que no establece ninguna prohibición expresa. La interpretación de la doctrina nacional a dicho enunciado se divide en dos sectores: el sector que entiende que dichos convenios son nulos y el sector que entiende que "lo que no está prohibido, está permitido" y que "el enunciado de la norma significa que la ley general de salud solo regula los supuestos donde la madre gestante y genética son la misma persona" como es el caso del último pronunciamiento del Tribunal Constitucional (F.D.N.R \& otros vs RENIEC, 2017). La jurisprudencia, en ese sentido, se ha mostrado más favorable a la ejecución de dichos convenios basándose en fundamentos que involucraban el interés superior del niño, derecho a la familia y derecho a la libertad personal.

En las siguientes líneas, se desarrollará un análisis a precisión de cómo funciona la legislación y mercado de vientre de alquiler en Perú con intención de teorizar el sistema que mejor se adapte a la realidad peruana. 


\subsubsection{Análisis del marco legal en Perú}

El Perú regula la maternidad subrogada a través de su jurisprudencia puesto que su mención de ley ha sido insuficiente y oscura dando lugar a distintas interpretaciones principalmente en la doctrina. A nivel jurisprudencial se ha optado por interpretar una “no regulación”, ello debido a que la ley N 26842 -Ley general de Salud, la encargada de regular la materia, en su artículo 7 menciona lo siguiente:

“Toda persona tiene derecho a recurrir al tratamiento de su infertilidad, así como a procrear mediante el uso de técnicas de reproducción asistida, siempre que la condición de madre genética y de madre gestante recaiga sobre la misma persona. (...)" (Ley General de Salud, 1997).

Los argumentos esgrimidos por el sector que entiende que dichos convenios son negocios jurídicos ilícitos son los siguientes:

“(a) Presenta objeto físicamente y jurídicamente imposible pues identifica al nasciturus como mercancía.

(b) Atenta contra el orden público porque se comercializa con el cuerpo humano.

(c) Es contrario a la ley por contradecir las normas naturales de filiación.

(d) Es un fraude a la institución de adopción. Si se permite el uso de este método, la regulación debe cambiar y establecer que la madre legal, en ese caso concreto, sea la madre genética para que no exista ningún fraude.

(e) Es contrario a la moral y buenas costumbres que se asemeja al contrato de prostitución." (Núñez, 2014, pp. 91-92):

Por otro lado, el sector que entiende que la misma no está regulada (dentro del cual se encuentra la última sentencia del Tribunal Constitucional sobre la materia), nos expresa los siguientes argumentos:

(a) El texto de la norma puede dar a entender que se limita el derecho de acudir a las TRAs solo para los casos en donde sirva para una procreación en donde el elemento genético de la madre coincida con su condición de gestante. Sin embargo, ello no significa que los otros 
supuestos no previstos en la norma estén proscritos, pues no se puede realizar una interpretación a contrario sensu de las normas que restringen derechos.

(b) Es necesario que la prohibición de celebrar contratos de acuerdos de maternidad subrogada sea expresa pues mientras tanto, "todo lo que no está prohibido, está permitido". Un argumento basado en el principio de legalidad

Esta última interpretación habría sido desarrollada en concordancia con los anteriores precedentes en el país. Es así que, de los casos de vientre de alquiler en el Perú, encontramos los siguientes:

El caso C.M.S.E. c/ J.L.A. de O. fue un caso resuelto en primera instancia en enero del 2009 por el décimo quinto juzgado de familia de Lima y trata de una impugnación de maternidad sobre un vientre de alquiler. Los hechos son los siguientes:

“(...) la señora C.M.S.E sufre de imposibilidad para gestar por lo que la pareja recurre a la fecundación in vitro con su propio material genético y además contando con la señora J.L.A que lleva a cabo la gestación subrogada. Al nacer, la niña es anotada como hija de la Sra. J.L.A de O. y su terno. Debido a ello, la madre genética impone una acción de impugnación de maternidad. La jueza entiende que la acción no es procedente en dicho caso pues que, debido a la fecundación in vitro, el concepto tradicional de maternidad resulta obsoleto por lo que ordena realizar una prueba de ADN que resulta favorable para C.S.M.E (...) Asimismo, la juzgadora afirma que no existe prohibición respecto de la maternidad subrogada, y que, por ende, se trata de una conducta licita, y que el acto altruista de la abuela de gestar a la nieta en favor de su hija y yerno, se define a favor de la madre genética, la señora C.S.M.E. En merito a ello, hace lugar a la acción recurriendo al "criterio de verdad" en la prueba de ADN." (Siverino, 2010, pp. 4041)

Por otro lado, también contamos con la Sentencia de Cas. № 563-2011 Lima de fecha 06 de diciembre de 2011, que resolvió un caso de vientre de alquiler que enfrentó a dos hermanos en un proceso de adopción por excepción. El caso versa sobre lo siguiente:

“El matrimonio de D.F.P.Q y G.S donde se encargó a I.Z.C.M la gestación de un niño a cambio de 18,900 dólares estadunidenses además del aporte de su óvulo (es decir, la hija gestada provenía de un gameto de la mujer gestante). Al nacer, la paternidad fue otorgada a la madre gestante y su pareja. Cabe recalcar que D.F.P.Q (demandante) era hermana del padre de la pareja 
de la gestante, es decir comúnmente conocida como "tía abuela de su hija". La niña fue entregada al nacer a los padres voluntarios y se inició el procedimiento de adopción, sin embargo, la pareja de la gestante desiste de continuar con la adopción argumentando que se habría realizado "de forma fraudulenta". Los padres voluntarios iniciaron un proceso penal contra la madre gestante y su pareja, argumentando que se les habría extorsionado al solicitarles cuantiosas sumas de dinero a efectos de no abortar, extorsión que se habría prolongado después del nacimiento con la amenaza de frustrar la demanda de adopción.

Pese al desistimiento de adopción, en las primeras dos instancias se declaró fundada la adopción interpuesta por los padres voluntarios, pero la gestante y su pareja interponen el recurso de casación argumentando que: i) no procedía la adopción dado que el padre adoptante era padre biológico de la menor y ello contravenía al artículo 115 del Código de Niños y Adolescentes, ii) porque la adoptante D.F.P.Q no guardaba ningún parentesco con la menor, iii) los adoptantes carecían de solvencia moral” (D.F.P.Q \&otros vs I.Z.C.M, 2011).

\section{La sentencia resuelve con los siguientes fundamentos:}

“(a) No es aplicable la primera causal pues el padre biológico de la menor solicitó la reproducción asistida de la clínica pero que P.F.P.C (pareja de la gestante) aparecía como padre legal a pesar que G.S era el padre legal.

(b) Existía un conflicto de interés superior de la niña a tener una familia y el derecho de los padres a ejercer la patria potestad. Y que basados en el comportamiento de la gestante y su pareja, dispuestos a renunciar a su hija a cambio de dinero, resolvió que había de prima el interés superior de la niña a que continúe viviendo con los demandantes, que según el tribunal proporcionaban un ambiente adecuado.

(c) Sería perjudicial para la niña arrancarla de su seno familiar a su corta edad.” (D.F.P.Q \&otros vs I.Z.C.M, 2011)

Por último, tenemos el caso de un amparo iniciado por una sociedad conyugal formada por F.D.N.R y A.N.B.V (padres voluntarios) \& otra sociedad conyugal formada por F.C.L.S.\& E.B.R.U (madre gestante y pareja) contra la RENIEC a efectos de dejar sin efecto una resolución que reconocía como padres a estos últimos. Los hechos narran lo siguiente: 
"De un contrato de subrogación suscrito entre los padres voluntarios y la madre gestante que incluía la "ovo donación". Realizado el procedimiento, nacieron dos mellizos inscritos con las iniciales L.N.N.R y C.D.N., no obstante, a pesar de la declaración expresa de la madre gestante de ser solo "el vientre alquilado", el médico tratante al momento de efectuar el certificado de Nacido Vivo inscribió como madre a esta última y como padre a su pareja.

Tomando como base esos mismos datos, el Registro Nacional de Identificación y Estado Civil-RENIEC, realizó el registro en las Actas de nacimientos y ante las impugnaciones realizadas, emitió las resoluciones registrales Nº 299-2016-ORSBORJ-JR10LIM-GOR/RENIEC y $\mathrm{N}^{\mathrm{o}}$ 300-2016-ORSBORJJR10LIM-GOR/RENIEC donde desestimaban los recursos" (La Ley.pe, 2017).

Por ello, los padres voluntarios presentaron una demanda considerando que dichas resoluciones registrales vulneran el derecho a la identidad y al interés superior del niño de los menores, asimismo, la afectación al libre desarrollo de la personalidad, a la vida privada y familiar, así como sus derechos sexuales y reproductivos. Ante ello el juzgado declaró fundada la demanda basándose en los siguientes argumentos:

“(a) El derecho a acceder a técnicas de reproducción asistida incluye los procedimientos donde el apoyo no solo sea tecnológico, sino también sea necesaria la cooperación adicional y necesaria de terceras personas como el caso de la maternidad subrogada conocida como "vientre de alquiler".

(b) La normativa del Estado no proscribe el uso de maternidad subrogada pues el artículo 7 de la Ley General de salud no puede interpretarse a contrario sensu pues es un artículo que limita derechos. La única interpretación válida es que el artículo 7 no regula más supuestos que la madre gestante comparta carga genética con su bebé. Interpretar a contrario sensu atentaría contra el principio de legalidad.

(c) Mientras no exista una expresa prohibición de celebrar contratos de maternidad subrogada o aplicar TRAs a supuestos distintos a los previstos al artículo 7 se entiende que se trata del ejercicio legítimo de los derechos a la salud reproductiva y otros vinculados.

(d) Las TRAs no están prohibidas, pero solo pueden ser empleadas cuando tuvieran como destino la formación de familia, pues lo contrario sería abrir una puerta peligrosa a la reproducción de seres humanos para múltiples propósitos. 
(e) Basándose en el interés de los menores se debe tener en cuenta que es conveniente ellos convivan con los padres que tienen la voluntad pro-creacional en lugar de la madre de alquiler la cual presentó desde un principio la voluntad de darlos en entregarlo.” (F.D.N.R \& otros vs RENIEC, 2017)

Por ello, en razón los casos expuestos en línea arribas, entendemos que la interpretación de que la legislación prohíbe la maternidad subrogada atenta contra el principio de legalidad, por lo cual se entiende que dichos convenios no se encuentran regulados. Asimismo, la voluntad pro-creacional es relevante en razón a su conexión con el interés superior del niño, pues implica que la pareja que desea tener al niño puede brindarle un mejor ambiente familiar. Finalmente, observamos que la legislación actual es insuficiente pues en ambos casos se ha recurrido a instituciones ajenas como los derechos de salud reproductiva, interés superior del niño y derecho al libre desarrollo de la personalidad para reconocer dichos convenios.

\subsubsection{Análisis del mercado e impacto en Perú}

La falta de regulación y el poco interés del estado en el desarrollo y potencial de la industria de fertilidad en el país es un obstáculo para la obtención de datos estadísticos. A pesar de ello, podemos estimar el crecimiento de dicha industria con la información del turismo médico y de fertilidad. De acuerdo a la ONG "Cluster Salud" el turismo medico ha movido alrededor de 258 millones de dólares en el país en el 2014, y se calcula que para el 2019 esta cantidad se proyecte a 337 millones de dólares (Cluster Salud, 2016). Asimismo, acorde al doctor Jaime Moya, representante de la asociación de clínicas particulares afirma que "los principales servicios de salud requeridos por los extranjeros son cirugías plásticas, odontología, oftalmología y fertilidad” (Redacción Peru21, 2012, párr.7).

Por otro lado, se estima que el negocio de la fertilidad podría iniciar un auge en los próximos años debido a los bajos costos en relación con otros países "el procedimiento de fecundación en vitro en Perú cuesta alrededor de 4000 a 10000 dólares, mientras en Europa y Estados Unidos se aproxima a los 30000 dólares. Se prevee que en 
el 2021 negocio de la fertilidad en el Perú mueva alrededor de 120 millones de dólares” (Salas, 2016, párr.6).

En las siguientes líneas buscaremos describir el mercado peruano de maternidad subrogada.

(i) La rivalidad de la industria

El Perú no cuenta con agencias dedicadas al corretaje de maternidad subrogada visibles en las aplicaciones electrónicas, sin embargo, acorde a la información obtenida de internet, "existen agencias internacionales que trabajan con clínicas de Perú, en países donde la maternidad subrogada es ilegal, como en España" (Equipo de Redacción de la República, 2006, párr.10) o donde existe oferta poco atractiva como en el Reino Unido. Por otro lado, resulta difícil cuantificar pues "la mayor cantidad de ofertas parece provenir de internet, en foros donde mujeres de 21 a 40 años ofrecen alquilar su vientre y en clínicas donde se coluden con ellas para dichas actividades" (Redacción El Comercio, 2014, párr.7). Cabe recalcar, que dicha industria es informal, "pues las clínicas donde se realizan estos procedimientos falsifican documentos a efectos de permitir el otorgamiento de paternidad a los padres voluntarios, práctica que constituye delito contra la fe pública, pero resulta común en nuestro medio" (Equipo de Redacción de la República, 2006). En ese sentido, al ser la industria informal pero supeditada a las clínicas para tener una "ventaja competitiva" (evitar un procedimiento de adopción o de reconocimiento de paternidad) tienen solo dicho canal para contratar con los consumidores. Por ende, de la observación de las clínicas de fertilidad, podemos estimar que su industria se encuentra atada a las 17 clínicas de fertilidad que se encuentran en Lima y Huancayo de acuerdo a las aplicaciones electrónicas. Asimismo, de los datos recogidos por la Sociedad Peruana de fertilidad, conocemos que cada año se realizan en "promedio 4,500 procedimientos de fertilización asistida" (Redacción El Comercio, 2014, párr.17), cantidad que se considera irá incrementando por los precios competitivos. Por estas razones, la industria de la maternidad subrogada aún no es altamente competitiva pues se encuentra concentrada en Lima y Huancayo, más se encuentra en desarrollo, con posibilidades de alcanzar un alto nivel de competencia si se explota el "turismo reproductivo" y los "precios bajos en fertilidad" en el país en relación con la competencia.

(ii) La amenaza de productos sustitutos 
La adopción en el Perú enfrenta un problema de altos costos en tiempo, ello debido a que el Poder Judicial demora hasta 2 años en algunos casos en emitir la resolución de abandono. De acuerdo al Ministerio de la Mujer y Poblaciones Vulnerables, “de los 46 albergues del Inabif hay 1787 niños y adolescentes atendidos por el Estado por estar desamparado y de estos, 321 han sido declarados en abandono por el Poder Judicial. Y en el 2016 se cuantificó 300 parejas en lista de espera para adoptar a un menor" (Fernández Calvo, 2016, párr.7). Ello nos lleva a pensar de un mercado restrictivo con oferta que presenta obstáculos para suplir la demanda de niños y una demanda insuficiente para los niños desamparados.

(iii) El poder de negociación de los consumidores

No existen indicios de un gran flujo de extranjeros en busca de maternidad subrogada en el Perú, por lo que es probable que gran parte de los consumidores sean locales. Estos gozan de poder de negociación antes de realizada la transacción dado que la situación del bebé es incierta y las madres no pueden proporcionar seguridad jurídica necesaria. El riesgo de realizar dichos procedimientos en el mercado peruano es mayor, pero a cambio obtienen un precio accesible, siendo que el vientre de alquiler en Perú suele encontrarse en un rango entre 8,000 a 18,000 dólares, por debajo de los precios en Estados Unidos. Por otro lado, una vez se inicia la gestación, la inseguridad jurídica puede devengar en una situación de extorsión, como nos expresa María Luisa Cuculiza, ex presidenta de la Comisión de la Mujer y Familia "Mientras el código penal no sancione, ni el Ministerio de salud no lo acepte, se presta a que las personas que tienen mala intención extorsionen a las parejas, ya no son 30,000 dólares...son 40,000 dólares." (Alvarado, 2012), problema que se ha suscitado a nivel jurisprudencial. En razón a ello, el poder de negociación de los consumidores es alto, y una vez realizada la transacción, se encuentran en una situación de total vulnerabilidad.

(iv) El poder de negociación de los proveedores

Las madres gestantes en el Perú, acorde a la información obtenida directamente a través de los medios electrónicos, tienen problemas para realizar dichas transacciones debido a la desconfianza de los padres previstos, por lo que requieren de las agencias que les brinden seguridad. En el Perú, la no existencia de dichas agencias dificulta las transacciones, por lo que su poder de negociación es reducido. Por otro lado, su costo de oportunidad reflejado en el índice de oportunidades económicas de las mujeres se 
encuentra en un nivel intermedio, siendo que "Perú se ubica en el puesto 54 con un puntaje de 53.0. 7" (Economist Intelligence Unit, 2012, p. 7). Ello nos dice que, a nivel del mercado internacional de subrogación, las mujeres peruanas si presentan otras oportunidades de desarrollo superiores a los países del sur-este asiático y del África por lo que pueden exigir precios más altos.

(v) Los factores externos

Si bien un factor positivo para la industria local de la subrogación es el cierre de los más grandes mercados de "vientre de alquiler internacional", es decir, el cierre a los extranjeros de Tailandia y la India, probablemente ello repercuta más en la demanda local que la demanda internacional. Ello se debe a que la oferta de mercados de maternidad subrogada a bajo riesgo y bajo precio ha disminuido, y los mercados más atractivos se convierten en aquellos que ofrecen un riesgo alto otorgado por la desregulación, pero un precio bajo (como Laos y Camboya o los países del sur-oeste asiático) o un bajo riesgo a un alto precio (como Estados Unidos, Canadá o Ucrania). América Latina ubica sus precios a nivel intermedio, por debajo de los norteamericanos y europeos, más por encima de los países del sur-este asiático ofreciendo el mismo riesgo que los países desregulados, por lo que existen mejores opciones que Perú para la subrogación para los extranjeros que otorgan el mismo riesgo. Por otro lado, para el mercado local el riesgo de trasladarse de dichos países por el mismo riesgo que el mercado local y a parecido similares, hace más atractiva la idea de celebrar dichos convenios en el Perú.

Adicionalmente, la industria del vientre de alquiler se podría ver beneficiada en los próximos años pues "existe una política proveniente del sector privado de salud con la intención de impulsar el turismo de salud en el país, acorde con el doctor Jaime Moya, representante de la Asociación de clínicas particulares” (Redacción Peru21, 2012, párr.4).

En consecuencia, el mercado peruano de vientre de alquiler al no estar regulado, es informal e involucra delitos como la falsificación de documentos en colusión con las clínicas. Las oportunidades de desarrollo económico de la mujer les permiten alcanzar un precio más alto que los países del sur-este asiático, pero menor a los países de Europa o Norteamérica. Por otro lado, el mercado de fertilidad en el país recién se está desarrollando e impulsar el turismo reproductivo puede traer grandes ganancias al país pues de regularse dichas técnicas, el Perú podría ofrecer un servicio a bajo costo y bajo riesgo. 


\subsubsection{Propuestas para un marco legal de la maternidad subrogada en el Perú}

En concordancia con las razones expuestas en los capítulos anteriores y atendiendo a las leyes del mercado y sobre las cuales actúa un individuo racional, entiendo que la legislación peruana debe optar por las siguientes directrices a efectos de permitir una adecuada asignación de recursos y mayor satisfacción entre partes:

a. La maternidad subrogada debe ser reconocida como válida y sus convenios deben ser ejecutables en la medida que la mujer no pueda desistir de entregar al niño a los padres voluntarios

Los convenios de maternidad subrogada permiten un intercambio eficiente de recursos donde los padres voluntarios logran ver satisfecho su deseo de procrear, y las madres subrogadas reciben una contraprestación económica que la permite elevar su nivel de vida. La posibilidad del desistimiento de la maternidad subrogada incrementa el riesgo en el contrato y le resta poder de negociación a las madres gestantes, además de basarse en una premisa discriminatoria la cual dice que "las madres gestantes no gozan de la capacidad la información suficiente para celebrar dicho tipo de convenios al ser capaces de valorizar correctamente el "costo emocional" de desprenderse de un hijo".

Por otro lado, la capacidad de desistirse a entregar el hijo impone una situación de vulnerabilidad a los padres voluntarios pues: los hace susceptibles a extorsiones por parte de las madres gestantes una vez iniciado el embarazo, les genera daño a sus expectativas de tener un hijo y genera costos de tiempo invertido.

b. Debe permitirse el ánimo de lucro y no deben existir límites ni bases al precio de la compensación

La limitación de precios o la condición de altruismo no solo genera insatisfacción en la madre gestante pues no vera maximizada su riqueza con dicha transacción ni podrá acceder a los máximos beneficios de su trabajo, sino que también genera insatisfacción en los padres previstos, pues se verán expuestos a un mercado con: escasez de oferta, informalidad y deterioro del servicio. Asimismo, el cumplimiento de dicha normativa es difícil de monitorear pues en los mercados donde se establecen límites al pago de las madres gestantes, se otorgan "regalos" que son difíciles de clasificar y regular. Dado el 
bajo nivel de institucionalidad en el país, el efecto más probable es que esta medida repercuta en un incremento de la informalidad.

c. Debe permitirse la existencia de agencias de maternidad subrogada

Las agencias cumplen la función de reducir el riesgo en dichos convenios pues prestan una especie de "garantía" en relación a las madres gestantes y si bien, incrementan los costos de transacción, son costos que los padres voluntarios prefieren pagar a contratar con una madre gestante directamente. Asimismo, brindan apoyo legal, contacto de las clínicas, valorización del presupuesto e información de los procedimientos, lo que otorga una serie de ventajas entre las partes pues las madres gestantes contactan con clientes y los padres voluntarios aumentan su confianza en dichas transacciones.

d. Debe permitirse la subrogación internacional

La prohibición al turismo reproductivo reduce la demanda internacional y la limita al mercado local obligando a las madres a disminuir los precios de compensación, y, por ende, su nivel de satisfacción con dichas transacciones. Asimismo, limita a las clínicas privadas de procedimientos que generarían importantes ingresos a nivel del país.

e. La forma más eficaz de lograr que las madres gestantes incrementen sus precios de compensación y obtengan mayores beneficios de dichas transacciones es aumentar su costo de oportunidad

Las normas favorables a la maternidad subrogada deben ir acompañadas con un aumento de oportunidades de la mujer para desenvolverse económicamente en otros ámbitos, de esta forma el mismo mercado se autorregulará y los precios aumentarán pues las mujeres encontrarán actividades igualmente atractivas.

f. La creación de un registro de madres subrogadas aumentaría la confianza entre las partes contratantes y permitiría una mejor fiscalización de dichas actividades

Entre los beneficios de un registro de madres gestantes encontramos: mayor seguridad para los padres voluntarios pues gozan de saber cuántos embarazos ha tenido la madre gestante evitando desistimientos por arrepentimiento o extorsión, permite cuantificar de donde provienen las madres gestantes y con ello, las zonas donde las mujeres carezcan de oportunidades de desarrollo económico, permiten una mejor fiscalización de dicha actividad y finalmente, el acceso a información nos abre las 
posibilidad de conocer las carencias, fortalezas, vulnerabilidad de las partes y el mercado, facilitando al estado la capacidad de actuar para equilibrarlas.

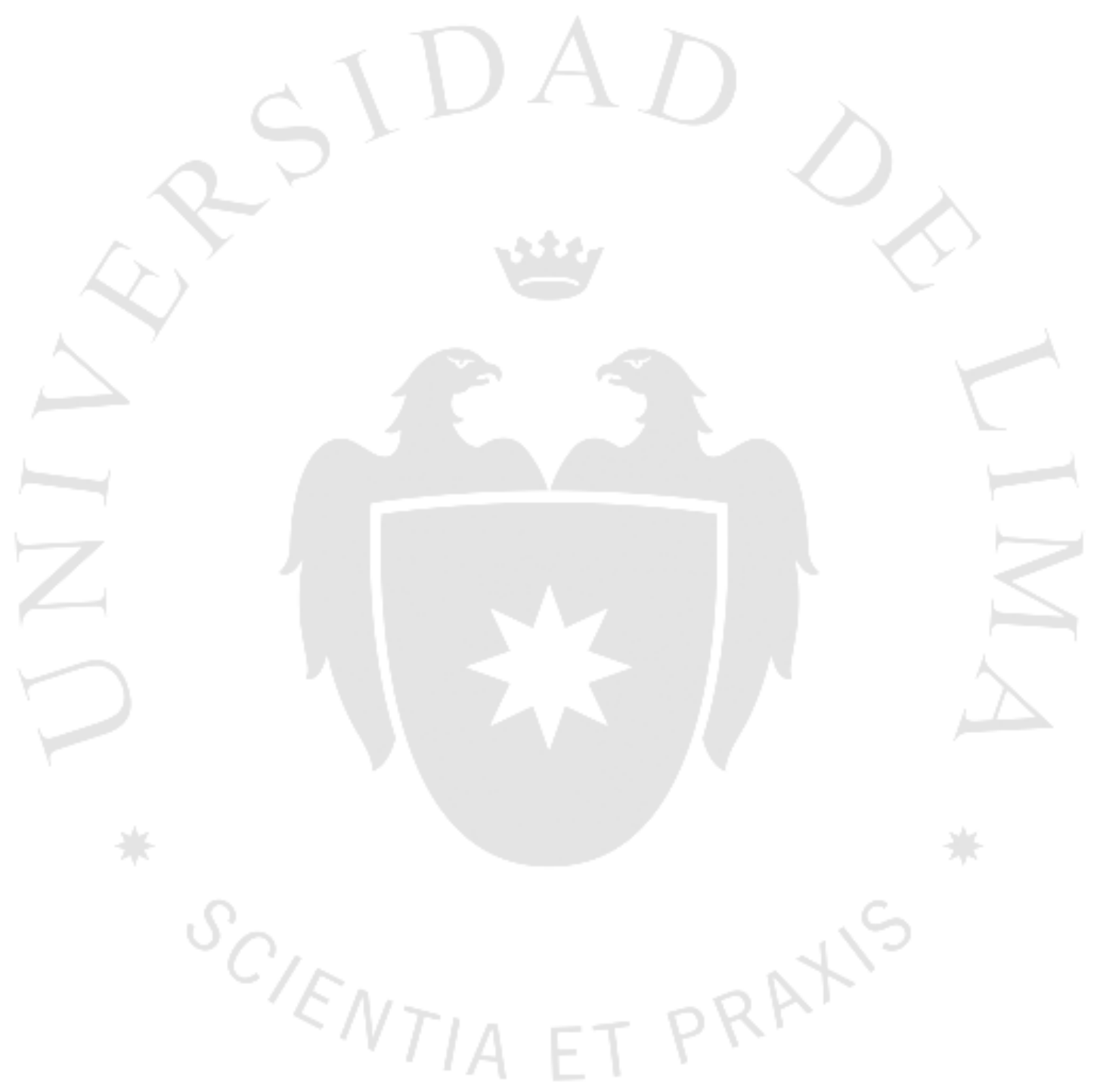




\section{CONCLUSIONES}

El objetivo del presente trabajo fue proponer directrices para una legislación de maternidad subrogada en el Perú a través de un enfoque del análisis económico del derecho orientado a la búsqueda de la maximización de la riqueza (felicidad) de las partes contratantes y de la sociedad.

La propuesta fundamentada en el apartado "3.1.3", se desarrolló teniendo en cuenta aspectos de la microeconomía, la macroeconomía y los factores sociales que influían específicamente dicho mercado. Asimismo, aportó una visión global, en el cual, "el fenómeno del turismo reproductivo" resulta un factor determinante en los precios de cada país. Finalmente, valiéndose de las herramientas del "Derecho comparado", "Esquemas analíticos de industrias” y estadística, se buscó apartarse del campo puramente teórico y ampliarse a un terreno más empírico.

A través del nuevo enfoque descrito, las conclusiones generales a las que se llegó en el presente ensayo fueron las siguientes:

1. El mercado de la maternidad subrogada es un medio que facilita el intercambio de recursos escasos entre las partes y permite que así alcancen mutuamente su satisfacción. La madre gestante cuenta con el recurso de la capacidad gestacional, la cual rentará a cambio de los recursos económicos de los padres voluntarios. De esa forma los padres voluntarios verán satisfecha su necesidad de procrear y la madre gestante podrá satisfacer otras necesidades.

2. El intercambio de recursos se suele realizar con asimetría entre las partes, tanto a nivel informativo como económico. La asimetría informativa es causada debido a la incapacidad de algunas madres de prever el costo emocional de desprenderse de un hijo y la asimetría económica por el usual estado de necesidad financiera en el que se encuentran las madres al momento de realizar dichos contratos, siendo vulnerables a cláusulas y/o precios "abusivos". 
3. A pesar de la existencia de las asimetrías antes mencionadas, una política de prohibición total de estos contratos no resulta beneficiosa para las madres gestantes ni para los padres voluntarios. A las primeras las perjudica evitando que reciban ingresos que mejorarían su situación de pobreza u obligándolas a entrar en la informalidad, en donde debido al incremento de riesgo, pierden poder de negociación y se ven forzadas a reducir sus precios en compensación. A los segundos los obliga a asumir un riesgo mayor en caso de ingresar a un mercado local informal o un costo mayor en caso de migrar al mercado reproductivo internacional.

4. Tampoco es beneficioso establecer una política de "control de precios" a las compensaciones de las madres subrogadas (como es el caso de la maternidad subrogada altruista o con precios limitados) pues genera: escases en la oferta, servicios inadecuados e incremento de la informalidad. Escases en la oferta debido a que, al disminuir la "recompensa", las madres gestantes se tornan a otras actividades más lucrativas. Los servicios inadecuados son ocasionados a causa de la disminución en el incentivo económico, que provoca que la madre gestante invierta menos tiempo y esfuerzo en realizar un servicio competente. Por último, resultaría en un incremento de la informalidad pues el "mercado negro" les permitiría a las madres gestantes recibir mayores beneficios que el "mercado formal con los precios controlados".

5. El "control de precios" o la "maternidad subrogada altruista" también genera costos al estado (como el de fiscalización) bajo pena que la norma sea ineficaz. A medida que aumenta el nivel de informalidad del país, mayores son los costos de fiscalización necesarios para mantener la eficacia de una norma.

6. Dentro de las medidas proteccionistas del mercado de la maternidad subrogada, específicamente la "restricción del acceso a los extranjeros" beneficia sólo a los padres voluntarios provenientes de dicho país y perjudican a las madres gestantes. Ello se debe a que, al encogerse la demanda en el mercado local, las madres gestantes se ven obligadas a reducir sus precios. La 
apertura al mercado internacional permite a las madres gestantes maximizar sus beneficios al tener acceso a más consumidores con mayor poder adquisitivo.

7. Las formas más eficaces por la que el estado puede aportar valor en el mercado de maternidad subrogada son brindando: seguridad jurídica, una adecuada institucionalidad y oportunidades socio-económicas para las partes. La seguridad jurídica otorga poder negocial a las madres gestantes pues reduce el riesgo de incumplimiento e incrementa la demanda, especialmente la internacional dado que esta constituye una ventaja competitiva entre los países que son destinos reproductivos. La adecuada institucionalidad permitirá que las partes estén dispuestas a asumir los costos de transacción pues sentirán que estos son recompensados por la garantía de seguridad y de ese modo el estado podrá fiscalizar mejor dichos convenios. Por último, permitir que las mujeres accedan a mejores oportunidades económicas y sociales, pues la mejor forma de evitar las "cláusulas abusivas" en dichos contratos, es dándoles acceso a la parte vulnerable (madres gestantes) a otras opciones de crecimiento financiero.

8. Las formas más eficientes por las que el estado puede reducir la demanda en el mercado de maternidad subrogada son: agilizar los procesos judiciales de "declaración en estado de abandono" o simplificar los procesos de adopción. Ello crearía incentivos para trasladar la demanda al mercado adoptivo, lo cual generaría más valor pues los recursos de los padres voluntarios atenderían necesidades sociales en conjunto con sus necesidades individuales.

9. Las agencias de maternidad subrogada suplen deficiencias propias del mercado como: la falta de confianza, el riesgo de incumplimiento del convenio y el "presupuesto incierto" con las siguientes acciones:

(i) Contactan a los padres voluntarios con madres gestantes (las cuales, debido a los estigmas, suelen ser difíciles de contactar y otorgar información)

(ii) Proporcionan el historial de anteriores subrogaciones de las madres gestantes

(iii) Contactan con asesoría jurídica y médica especializada 
(iii) Otorgan un presupuesto previo de todos los costos (médicos, jurídicos y compensatorios) permitiendo a los padres voluntarios tomar una decisión más informada.

(iv) Crean mayor confianza en los padres voluntarios, lo que les permite a las madres gestantes acceder a compensaciones más altas.

Si bien es cierto generan mayores costos, sus servicios aportan valor a las transacciones pues permiten a las partes alcanzar posiciones más satisfactorias.

10. De lo observado en el análisis estadístico de regresión lineal presente en el apartado "1.3.3.4", se comprueba la existencia de una fuerte correlación directa entre las oportunidades de desarrollo económico de las mujeres y los precios de las madres subrogadas en cada país. Es decir, en los países que presentan mejores oportunidades económicas para las mujeres, las madres gestantes logran acceder a mayores montos de compensaciones por maternidad subrogada. Ello es causado por un alza en el costo de oportunidad, pues si la madre gestante no recibe una compensación satisfactoria, tiene la posibilidad de tornarse a otra actividad más lucrativa. Esto nos permite concluir que una política efectiva con el objetivo de "evitar la explotación de las madres gestantes" sería el empoderamiento femenino, es decir; proporcionarles condiciones favorables para su desarrollo como la educación adecuada o capacitación laboral entre otras. 


\section{REFERENCIAS}

\subsection{Obras Generales}

A. GreenLaw, S., \& Taylor, T. (2014). Principles of Macroeconomics. Texas: OpenStax editions.

Espinoza Espinoza, J. (2004). Derecho de las personas. Lima: Editorial Gaceta Juridica.

Miller, R., \& Meiners, R. (1989). Microeconomia. Bogotá: Editorial Mc Graw Hill.

Rawls, J. (2000). Teoria de la Justicia. Fondo de la Cultura Económica. Nueva York D.F: Editorial Columbia University Press Nueva York

\subsection{Obras especializadas}

Bullard, A. (2009). Derecho \& Economía. Lima: Palestra Editores S.A.C.

Cárdenas, R. (2008). Temas de Bioética y Derecho. In J. Abellán, A. S. Andruet, R. Cárdenas, M. De La Flor, M. Falla, V. Guevara,. P. Wagner, Temas de Bioética y Derecho (pp. 71-95). Lima: Grandez Gráficos S.A.C.

Casado, M. (2017). De la solidaridad al mercado. El cuerpo humano y el comercio biotecnológico. Barcelona: Edicions de la Universitat de Barcelona.

L.P.Piffano, H. (2012). Analisis Económico del Derecho Tributario. La plata: Editora de Universidad Nacional de la Plata.

Pande, A. (2014). Wombs in Labor: Transnational Commercial Surrogacy in India. Carolina: Columbia University Press.

Peralta Andia, R. (2004). Derecho de Familia en el Codigo Civil. Lima: Editorial Moreno S.A.

Rubio Correa, M. (1996). Las reglas del amor en probetas de laboratorio. Lima: PUCP Editorial.

Seijas Rengifo, T. d. (1998). Estudios sobre los aspectos juridicos de la Biotecnologia reproductiva humana en el Peru. Lima: Editorial Universidad Nacional Mayor de San Marcos. 
Sivila Peñaranda, G. (2004). Bioética y derecho: Genesis, lineamientos, interacción y bases para la acción. La Paz: Creativa Editorial.

Think Action Development. (2013). Dilemas actuales: respuestas humanas. Mexico DF. Comité editorial de México Presidente Jaime Del Valle.

Van Renssenlaer, E. (1971). Bioethics: Bridge to the Future. Michigan: Michigan States University Press.

Varsi, E. (2013). Derecho Genético: principios generales. Lima. Editorial Griley

Villarán Contavalli, A. (2003). La bioética y el derecho genético: Acercamiento crítico a ambas disciplinas. Lima: Universidad de Lima Fondo de Desarrollo Editorial.

\subsection{Legislación \& Jurisprudencia Nacional}

D.F.P.Q \&otros vs I.Z.C.M, CAS. N 563-2011 (Corte Suprema de Justicia del Perú, 06 de Diciembre de 2011).

F.D.N.R \& otros vs RENIEC, EXP. N. ${ }^{\circ}$ 00147-2017-Q/TC (Tribunal Constitucional del Perú, 20 de Diciembre de 2017).

Ley General de Salud, Ley N²6842 (Diario Oficial el Peruano, Perú, 9 de Julio de 1997)

\subsection{Legislación \& Jurisprudencia Extranjera}

Assembly Bill-1217, AB 1217-Chapter 466 (Secretario del Estado, California, 23 de Septiembre de 2012).

Baby Cotton, Case No: FD14P00262 (Corte Real de Justicia del Reino Unido, 30 de April de 2015).

Baby Manji Yamada vs Union Of India, NO. 369 OF 2008 (Suprema Corte de la India, 29 de Septiembre de 2008).

Casación STS 247/2014, CAS STS 247/2014 (Tribunal Supremo Español Sala de lo Civil , España, 6 de Febrero de 2014).

Instrucción del 7 de Octubre del 2010 DGRN, DGRN-15317 (Ministerio de Justicia Español, 07 de Octubre de 2010).

Johnson v. Calvert, No. S023721 (Corte Suprema de California, 20 de Mayo de 1993). K.M v. E.G, S125643 (Corte Suprema del Estado de California, 22 de Agosto de 2005). 
Kristine H. v. Lisa R., S126945 (Corte Suprema del Estado de California, 22 de Agosto de 2005).

Ley de técnicas de reproducción Asistida, N 35-1998 (Boletín Oficial del Estado, España, 22 de Noviembre de 1998).

Ley Nacional de Fertilización Asistida, N 26.862 (Boletín Oficial República Argentina, Argentina, 25 de junio de 2013)

N. N. o D. G. M. B. M. s/ inscripción de nacimiento, 38316/2012 (Juzgado de Nacimiento de primera instancia civil N 86 de España, 18 de Junio de 2013).

O.A.V., G.A.C. \& F.J.J., Nº714/15/1F (Primer Juzgado de Familia Mendoza Argentina, 29 de Julio de 2015).

Paradiso\&Campanelli vs Italy, 25358/12 (Segunda Sección de la Corte Europea de Derechos Humanos, 27 de Enero de 2015).

Paradiso\&Campanelli vs Italy, 25358/12 (Gran Sala de la Corte Europea de Derechos Humanos, 24 de Enero de 2017).

RJ 2009/1735, RJ 2009/1735 (Dirección General de Registros del Notariado, 18 de Febr ero de 2009).

Surrogacy Arrangements Act 1985, Act N 1985 Chapter 49 (London Gazzette, Reino Unido, 4 de Enero de 1985).

\subsection{Artículos de revistas digitales}

Aarefa, J. (2015). Why some parents are paying more than the official fee to adopt a child. Obtenido de Scrollin.: https://scroll.in/article/743276/why-some-parentsare-paying-more-than-the-official-fee-to-adopt-a-child

Block, W. (2002). Rent control. Obtenido de The concise Encyclopedia of Economics: http://www.econlib.org/library/Enc1/RentControl.html

Busardo, F., Gulino, M., Napoletano, S., Zaami, S., \& Frati, P. (2014). The Evolution of Legislation in the Field of Medically Assisted Reproduction and Embryo. Obten ido de Hindawi: https://www.hindawi.com/journals/bmri/2014/307160/ 
Ferrini, L. (2012). The importance of Institutions to Economic Development. Obtenido de E-International Relations Students: https://www.e-ir.info/2012/09/19/theimportance-of-institutions-to-economic-development/

Mowbray, N. (2017). To Have And To Hold: The Rise Of Surrogacy In Britain. Obtenido de British Vogue: http://www.vogue.co.uk/article/surrogacy -in-the-uk

Otilio Reyes, B., \& Franklin Sam, O. (2014). Teoría del Bienestar y el óptimo de pareto como problemas microecnómicos. Obtenido de: Revista Electrónica d e Investigación en Ciencias Económicas: https://www.lamjol.info/index.php/CA LERA/article/view/2657/2408

Smith, E., Behrmann, J., Martin, C., \& Williams-Jones, B. (2010.). Reproductive tourism in Argentina: Clinic accreditation and its implications for consumers, health professionals and policy makers. Obtenido de Developing World Bioethics: http s://onlinelibrary.wiley.com/doi/abs/10.1111/j.1471-8847.2009.00256.x

Thériault, A., \& Palacio, M. J. (2012). Reinventar a la cigüeña. Obtenido de Ideele: https://revistaideele.com/ideele/content/reinventar-la-cig\%C3\%BCe\%C3\%B1

\subsection{Artículos de revistas impresas}

Annas, G. (2004). American Bioethics and Human rights; the end of all our exploring. Journal of Law, Medicine \& Ethics, 659

Arjona Trujillo, A. M., \& Rubio Pardo, M. (2002). El análisis economico del derecho. Precedente, 118-149.

Baffone, C. (2013). La maternidad subrogada una confrontacion entre Italia y Mexico. Boletin Mexicano de Derecho Comparado, 441-470.

Boladeras, M. (2004). Bioetica: Definiciones, practicas y supuesto antropologicos. Themata. Revista de filosofia, 384.

Calvo Caravaca, A.-L., \& Carracosa Gonzáles, J. (2011). Notas críticas en torno a la instrucción de la dirección general de los registros y del notariado de 5 de octubre 2010 sobre régimen de la filiación de los nacidos mediante gestación por sustitución. Cuadernos de Derechos Transnacional, 247-262. 
Cárdenas, R. (2015). Fecundacion asistida y consentimiento informado. Que tan informado es el consentimiento. LUMEN, 19-31.

Casanello, P., A.Castro-Rodriguez, J., \& Uauy, R. J. (2016). Programacion epigenetica placentaria en restriccion del crecimiento intrauterino. Revista Chilena de Pediatria, 154-161.

Domenech Pascual, G. (2014). Por qué y cómo hacer análisis economico del derecho. Revista de Administracion Publica, 99-133.

F.Brining, M. (1995). “A Maternalistic Approach to Surrogacy: Comment on Richard Epstein's Surrogacy: The. Notre Dame Law School, 2337-2399.

Ferrer Lues, M. (2003). Equidad y Justicia en Salud: implicancia para la Bioetica. Acta Bioethica, 113-126.

G.York, S. (1991). A contractual analysis of subrogate motherhood and proposed solution. Loyola Los Angels Rev, 395-420.

García Delfino, M. (2013). Nuevas perspectivas sobre la financiación pública de las técnicas de reproducción. Revista de derecho de familia y de las personas, 87103.

García Maynez, E. (1941). La libertad como Derecho. Biblioteca Juridica Virtual del Instituto de Investigaciones Juridicas de la UNAM, 101-112.

Guzmán, B. (2001). El tradicionalismo del Código Civil Peruano 1852. Scielo, 547-565.

León, F. (1995). Dignidad Humana, Libertad y Bioetica. Aris Brevis, 103-124.

Lyndon, M. (2011). "Surrogate Mothering" and Women's Freedom: A Critique of Contracts for Human. Sign. Chicago Journal, 618-639.

N.Hatzis, A. (2003). Just the Oven: A law\&Economics Approach to Gestational Surrogacy Contracts. Intersentia, 412-433.

North, D. C. (1991). Institutions. Journal of Economic Perspectives, 97-112.

Núñez, A. (2014). Derechos reproductivos de la mujer infértil en el Peru: acceso a la tecnica de reproduccion asistida de maternidad subrogada. Foro juridico, 89-99. 
Parisi, F., \& W.F Depoorter, B. (2001). "Private Choices and Public Law: Richard A. Posner. Contributions to Family Law and. Journal of Contemporary Health Law \& Policy, 403-427.

Posner, R. (1985). Wealth Maximization Revisited. Journal of Law, ethics and public policy, 85-105.

Posner, R. (1989). The ethics and Economics of Enforcing Contracts of Surrogate Motherhood. University of Chicago Law School, 21-31.

Rammonhan, M., \& Kare, P. (2013). Economic Analysis of Commercial Surrogacy. Journal of legal studies and research, 45-54.

Salvador, D. (2015). Diez años de la Declaración Universal sobre Bioética y Derechos Humanos. Revista Bioética, 447-454.

Sanabria, C. (2000). Equidad en Salud. Sintesis, 1-2.

Sierra, X. (2011). Ética e investigación médica en humanos: perspectiva histórica. Actas Dermo Sifiliograficas, 395.

Siverino, P. (2010). ¿Quién llamó a la cigüeña? Maternidad impugnada e identidad genética, reflexiones a propósito de dos sentencias peruanas. Revista Juridica UCES, 19-42.

Smith Nightingale, D., \& A.Wandner, S. (2011). Informal and Nonstandard Employment in the United States. The Urban Institute, 1-7.

V.Mc Lachlan, H., \& Swales, K. (2009). Commercial surrogate motherhood and the alleged commodification of children: a defense of legally enforceable contract. Law and Contemporary Problem, 91-107.

Vera Carrasco, O. (2016). El consentimiento informado del paciente en la actividad asistencial medica. Revista Medica La Paz, 59-68.

\subsection{Artículos Periodísticos}

Altarriba, M. (19 de Marzo de 2017). Ronaldo, Bosé y otros papás por subrogación. Obtenido de "El periódico Catalunya": https://www.elperiodico.com/es/gente/2 0170319/cristiano-ronaldo-miguel-bose-vientres-de-alquiler-5906585 
Antún, L. (20 de Agosto de 2015). "Hasta nunca”: cerró Argentina Maternity luego del escándalo de alquiler de vientres en Mendoza. Obtenido de: “Diario Los Andes 135 ”: https://www.losandes.com.ar/article/-hasta-nunca-cerro-argentinamaternitty-luego-del-escandalo-de-alquiler-de-vientres-en-mendoza

BBC Mundo. (20 de Febrero de 2015). Tailandia prohíbe la maternidad subrogada a extranjeros. Obtenido de “BBC Mundo”: https://www.bbc.com/mundo/ultimas_ noticias/2015/02/150220_ultnot_tailandia_subrogacion_madre_gammy_ley_pro hibicion_jmp

Bindel, J. (01 de April de 2016). Outsourcing pregnancy: a visit to India's surrogacy clinics. Obtenido de “The Guardian”: https://www.theguardian.com/globaldevelopment/2016/apr/01/outsourcing-pregnancy-india-surrogacy-clinics-juliebindel

Borja, R. (19 de Febrero de 2017). Las adopciones internacionales caen un $85 \%$ en diez años. Obtenido de “Diario El mundo”: http://www.elmundo.es/sociedad/2017/0 2/19/58a7518fca47416c048b45e0.html

Curtis, P. (30 de Septiembre de 2011). Reality check: why are so few children being adopted? Obtenido de "The guardian": https://www.theguardian.com/politics/re ality-check-with-polly-curtis/2011/sep/29/reality-check-adoption

EFE Agencia. (5 de Marzo de 2017). La gestación subrogada se dispara en España ante la caída de la adopción internacional. Obtenido del “Diario el Mundo”: http://w ww.elmundo.es/sociedad/2017/03/05/58bbe43cca4741c1428b4579.html

Equipo de Redacción de la República. (12 de Diciembre de 2006). Canal español destapa red de "vientre de alquiler en Lima". Obtenido de "Diario La república": https://larepublica.pe/politica/265920-canal-espanol-destapa-red-de-vientres-dealquiler-en-lima

Equipo de redacción Peru21. (20 de Diciembre de 2014). Trabas para adoptar: Cerca de 15 mil niños peruanos esperan por un hogar. Obtenido de "Perú 21": https://peru21.pe/lima/trabas-adoptar-cerca-15-mil-ninos-peruanos-esperanhogar-201943 
Fernández Calvo, L. (25 de Diciembre de 2016). El lento camino de la adopción en el Perú. Obtenido de "Diario El comercio": https://elcomercio.pe/peru/lentocamino-adopcion-peru-155624

G. Basterra, F. (19 de Enero de 1997). Dilema de Baby M. Obtenido de "El pais": https://elpais.com/diario/1987/01/19/sociedad/538009202_850215.html

Gayle, D. (06 de Mayo de 2015). High court orders surrogate mother to hand baby to gay couple. Obtenido de “The Guardian” : https://www.theguardian.com/law/2015/ may/06/high-court-orders-surrogate-mother-baby-gay-couple

Grupo de redaccion de "El mundo". (28 de Abril de 2005). España, primer país de la UE y segundo del mundo en adopciones internacionales. Obtenido de "Diario el mundo: http://www.elmundo.es/elmundo/2005/04/28/sociedad/1114696591.html

Grupo de redacción de The Indian Express News. (06 de Marzo de 2017). No commercial surrogacy, only for needy Indian couples, Govt tells SC. Obtenido de "The indian express news": http://indianexpress.com/article/india/india-news-india/govt-tomake-commercial-surrogacy-illegal-panel-to-decide-on-cases-of-infertilecouples/

Huérfano, E. (26 de Septiembre de 2013). Economía informal y crimen, en estrecha relación. Obtenido de "El economista”: https://www.eleconomista.com.mx/sect orfinanciero/Economia-informal-y-crimen-en-estrecha-relacion-201309260039.html

Infobae. (15 de Junio de 2013). Por qué es tan difícil adoptar en Argentina. Obtenido de Info Buenos Aires Económico (Infobae): https://www.infobae.com/2013/06/15/7 15635-por-que-es-tan-dificil-adoptar-argentina/

Izquierdo, G. (01 de Febrero de 2016). La fijación de precios solo trae colas y mercado negro. Obtenido de "Diario El comercio" : https://elcomercio.pe/economia/dia1/fijacion-precios-trae-colas-mercado-negro-268505

Lahrichi, K. (05 de Octubre de 2016). Watch: In Argentina, a Boom in Fertility Tourism. Obtenido de "Usnews": https://www.usnews.com/news/best countries/articles/2 016-10-05/watch-in-argentina-a-boom-in-fertility-tourism 
Lakshmi, R. (24 de Marzo de 2015). India moves to improve 'shameful' record on orphan adoptions. Obtenido de "The washington post": https://www.washingtonpost.co $\mathrm{m} /$ world/asia_pacific/india-moves-to-improve-shameful-record-on-orphanadoptions/2015/03/20

Larrañeta, A. (17 de Noviembre de 2014). Un millar de niños españoles nacen cada año en el extranjero a través de madres de alquiler. Obtenido de "20 Minutos": https://www.20minutos.es/noticia/2292573/0/ninos-espanoles/maternidadsubrogada/extranjero/

Lindsay, R. (05 de Abril de 1987). Adoption market: Big demand, tight supply. Obtenido de “The New York Times": https://www.nytimes.com/1987/04/05/us/adoptionmarket-big-demand-tight-supply.html

M. J García, M. J. (30 de Julio de 2016). El tiempo medio de espera para una adopción nacional es de cinco años. Obtenido de "Diario El correo": http://elcorreoweb.e s/andalucia/el-tiempo-medio-de-espera-para-una-adopcion-nacional-es-decinco-anos-AC2040002

Mannino, P. (21 de Agosto de 2015). Investigan a una agencia por alquiler de vientres en Mendoza. Obtenido de "La nación”: https://www.lanacion.com.ar/1821112investigan-a-una-agencia-por-el-alquiler-de-vientres-en-mendoza

Muffit, E. (07 de Mayo de 2015). How to have a baby by surrogate in the UK. Obtenido de "The telegraph": https://www.telegraph.co.uk/women/mothertongue/115835 45/How-to-have-a-baby-by-surrogate-in-the-UK.html

MVS Noticias. (03 de Mayo de 2016). Diputados alertan trata de personas con maternidad subrogada. Obtenido de "MVS Noticias": http://www.mvsnoticias.c om/\#!/noticias/diputados-alertan-trata-de-personas-con-maternidad-subrogada854

Panthaky, S. (25 de Agosto 2015). India moves to ban surrogacy for potential foreign parents. CBS Obtenido de "CBS News": https://www.cbsnews.com/news/indiaban-surrogacy-potential-foreign-parents/

Ponniah, K. (13 de Febrero de 2018). In search of surrogates, foreign couples descend on Ukraine. Obtenido de "BBC News": https://www.bbc.com/news/world-europe42845602 
Redacción BBC Mundo. (02 de Agosto de 2014). Pareja australiana abandona bebé con síndrome de Down de madre subrogada. Obtenido de "BBC Mundo": https://www.bbc.com/mundo/ultimas_noticias/2014/08/140802_ultnot_australia _bebe_down_wbm

Redacción El Comercio. (22 de Junio de 2014). Peruanas ofrecen alquilar su vientre a S/.70 mil en internet. Obtenido de "Diario El Comercio": https://elcomercio.pe/1 ima/peruanas-ofrecen-alquilar-vientre-s-70-mil-internet-332746

Redacción Peru21. (12 de Noviembre de 2012). Promoverán turismo de salud en Perú. Obtenido de "Peru21" : https://peru21.pe/economia/promoveran-turismo-saludperu-55720

Reina, L. (07 de Julio de 2012). Ya hay alquileres de vientres en el país. Obtenido de " $L a$ nación": https://www.lanacion.com.ar/1488504-ya-hay-alquileres-de-vientresen-el-pais

Salas, L. (28 de Marzo de 2016). Perú: Negocio de la fertilidad movería US\$120 mlls. el 2021. Obtenido de "Diario El comercio”: https://elcomercio.pe/economia/dia1/peru-negocio-fertilidad-moveria-us-120-mlls-2021-176872

Sherwell, P. (18 de Noviembre de 2015). India surrogacy ban dismays British couples. Obtenido de “The telegraph”: https://www.telegraph.co.uk/news/worldnews/asi a/india/12001903/India-surrogacy-ban-dismays-British-couples.html

Taneja, P. (20 de Octubre de 2011). The childless UK couples considering Indian surrogates. Obtenido de “BBC News”: https://www.bbc.co.uk/news/uk-15354443

Tarishi, V. (06 de Marzo de 2017). What are the surrogacy laws in India: Here is everything you need to know. Obtenido de "The indian express" :http://indianex press.com/article/research/karan-johar-surrogate-children-yash-roohi-what-arethe-surrogacy-in-laws-in-india-here-is-everything-you-need-to-know-4555077/

Thapliyal, M. (23 de Octubre de 2017). India outlawed commercial surrogacy - clinics are finding loopholes. Obtenido de "The conversation": http://theconversation.c om/india-outlawed-commercial-surrogacy-clinics-are-finding-loopholes-81784 
The Guardian. (28 de Octubre de 2015). India bans foreigners from hiring surrogate mothers. Obtenido de “The Guardian”: https://www.theguardian.com/world/201 5/oct/28/india-bans-foreigners-from-hiring-surrogate-mothers

Urdinez, M. (09 de Octubre de 2017). Diez trabas de la adopción: pese a los avances, muchos chicos aún esperan. Obtenido de "La nación”: https://www.lanacion.co m.ar/2070452-diez-trabas-de-la-adopcion-pese-a-los-avances-muchos-chicosaun-esperan

Urra, S. (03 de Julio de 2017). Will Spain ever legalize surrogacy? Obtenido de El país: https://elpais.com/elpais/2017/06/29/inenglish/1498737625_194033.html

Velasco Hdez, I. (03 de Diciembre de 2015). ¿Formar familia a cualquier precio? Obtenido de “Diario El mundo”: http://www.elmundo.es/cronica/2013/11/17/52 8660b00ab74029508b4577.html

Ximénes de Sandoval, P. (23 de Febrero de 2017). Por qué California es la meca de la gestación subrogada. Obtenido de “El pais”: https://elpais.com/internacional/20 17/02/23/actualidad/1487854048_748059.html

\subsection{Documentales o Reportajes Periodísticos}

Alvarado, V. (Dirección). (2012). El Vientre de Alquiler en el Perú Reportaje ganador II Festival de Reportajes TV 2012 [Reportaje Periodístico].

Ashok, P. (Dirección). (2016). India's Missing Girls: BBC Documentary [Documental]

Enfoque Televisión. (2014). Maternidad subrogada en España. [Reportaje Periodístico].

Kapur, M. (Dirección). (2013). Las madres sustitutas, un negocio en la India [Reportaje Periodístico].

\subsection{Informes/Reportes/Guías}

Comité de Bioética de España. (2017). Informe del Comité de Bioética de España sobre los aspectos éticos y jurídicos de la maternidad subrogada. Bilbao, España. Obt enido de http://assets.comitedebioetica.es/files/documentacion/es/informe_comit e_bioetica_aspectos_eticos_juridicos_maternidad_subrogada.pdf

Economist Intelligence Unit. (2012). Women's economic opportunity. Missouri \& Missipi: Joanne McKenna Press Officer. 
H.Schawartz, G. (2016). Parentage litigation reference guide. Beverly Hills: Glen H. Judicial Press Office.

Horsey, K., Smith, N., Norcross, S., Ghevaert, L., \& Jones, S. (2015). Surrogacy in the UK: Myth busting and reform. London, United Kingdom. Obtenido de https://www.familylaw.co.uk/system/froala_assets/documents/27/Surrogacy_in_ the_UK_report.pdf

Indian Council of Medical Research. (2002). Ethical Guidelines for Biomedical Research on Human Participants. New Delhi, India. Obtenido de https://mciindia.org/kno w/rules/ethics.htm

International Labour Organization. (2018). Informal Employment. Obtenido de International Labour Organization(Página oficial de la Organización Internacion al del Trabajo): http://www.ilo.org/global/lang--en/index.htm

Ministerio de Relaciones Exteriores del Estado Peruano. (2007). Memorando AJU $N^{\circ}$ 173-2007. Lima.

Mujer, Madre y Profesional. (2015). Vientre de alquiler. Una nueva forma de explotacion de la mujer. Madrid: Profesionales por la ética.

National Commission for the Protection of Human Subjects of Biomedical and Behavioral Research. (1979). The Belmont Report. USA: US. Government Printing Office, Washington.

Northwest Surrogacy Center LLC. (2017). Infographic NWSC. San Francisco, California, United states: Northwest Surrogacy Center LLC email.

Organización Mundial de la Salud. (1993). Pautas para la Buena practica Cliinica. Obtenido de Portal de información Medicamente Esenciales y productos de salud.: Pautas para la Buena práctica Clínica: http://apps.who.int/medicinedocs/ documents/s18627es/s18627es.pdf

Ruiz, R. (2013). Maternidad subrogada "Revision bibliografica". (Tesis de pregrado) Universidad de Cantabria, Cantabria. 


\subsection{Recursos electrónicos}

Adoption Network Law Center. (26 de Enero de 2018). Adoption Network Law center. Obtenido de https://adoptionnetwork.com: https://adoptionnetwork.com/howlong-does-it-take-to-adopt-a-child

American Adoptions. (02 de Enero de 2018). American Adoption Agency. Obtenido de http://www.americanadoptions.com/adopt/the_costs_of_adopting

Asociación Médica Mundial. (21 de Marzo de 1964). Declaracion de Helsinki. Obtenido de Asociacion Medica Mundial: http://www.medicina.uanl.mx/investigacion/wpcontent/uploads/2014/07/IG-Helsinky-01.pdf

Babygest. (22 de Febrero de 2018). Babygest.com. Obtenido de Official Website Babygest: https://www.babygest.es/foro/tema/clinicas-de-maternidadsubrogada-en-california/

Business 11. (05 de Enero de 2017). Businessinvestment11.weebly.com. Obtenido de https://businessinvestments11.weebly.com/what-events-would-move-thedemand-curve.html

Business Dictionary. (28 de Enero de 2018). Businessdictionary.com. Obtenido de Sitio web de terminología de Negocios: http://www.businessdictionary.com/definitio n/bought.html

California Legislative Information. (02 de Febrero de 2017). California Legislative Information. Obtenido de: http://leginfo.legislature.ca.gov/faces/codes_displayT ext.xhtml?lawCode=FAM\&division=12.\&title=\&part=7.\&chapter $=\&$ article $=$

Centro de Bioetica. (16 de Febrero de 2017). La prohibición de la maternidad subrogada en Argentina. Obtenido de Centro de Bioética: http://centrodebioetica.org/2017/ 02/la-prohibicion-de-la-maternidad-subrogada-en-argentina/

Centro de Derecho y Religión. (17 de Julio de 2018). Centro de Derecho y Religion. (Organismo de la Pontificia Universidad Católica de Chile). Obtenido de (Página web Organismo de la Pontificia Universidad Católica de Chile): http://derechoyr eligion.uc.cl/en/docman/actualidad/392-proyecto-de-ley-de-gestacion-sustituidaen-argentina/file 
Cluster Salud. (05 de Febrero de 2016). America economia. Cluster Salud. Obtenido de Pagina oficial de Cluster Salud: https://clustersalud.americaeconomia.com/turis mo-medico-en-latinoamerica-se-duplica-en-cinco-anos-pero-ralentizaracrecimiento

Experimental Economics Center. (2006). EconPort. Obtenido de Andrew Yound School at Georgia State University: http://www.econport.org/content/handbook/Equilibr ium/Price-Controls.html

Fernández, I. O. (20 de Junio de 2004). La teoria de la programacion fetal y el efecto de la ansiedad materndad durante el embarazo en el neurodesarrollo infantil. Obtenido de Pagina oficial del Ministerio de Sanidad, consumo y bienestar social de España: http://www.msssi.gob.es/organizacion/sns/planCalidadSNS/pdf/equi dad/programacionFetal.pdf

Fernández, S. (25 de Enero de 2017). Babygest. Obtenido de Babyget.es: https://www.b abygest.es/turismo-reproductivo/

La Ley.pe. (17 de Abril de 2017). Laley.com. Obtenido de La ley Angulo legal de la noticia: http://laley.pe/not/3933/pj-reconoce-como-madre-a-quien-contrato-unvientre-de-alquiler/

Mainetti, J. A. (1989). Bioetica net. Obtenido de Página web de Margarita Boleras: http://www.bioeticanet.info/documentos/Nuremberg.pdf

NGA Law. (Abril de 2017). NatalieGambleassociates.co. Obtenido de Página web de "NGA de estudio de abogados": http://www.nataliegambleassociates.co.uk/kno wledge-centre/history-of-uk-surrogacy-law

Pandey\&Associates Advocates. (7 de Marzo de 2017). Pandey\&Associates Advocates.blogspot. Obtenido de Blog de Estudio de Abogados: http://pandeyas sociatesoffice.blogspot.com/2017/03/law-relating-surrogacy-in-india.html

Pérez Billinghurst, G., \& Cornejo, S. (06 de Octubre de 2015). Economía informal. Un enfoque desde la institucionalidad, productividad y educación. Obtenido de Sitio Web del Círculo de Estudios de Economía y sociedad de la Universidad de Lima: https://cedesulima.wordpress.com/2015/06/10/economia-informal-un-enfoquedesde-la-institucionalidad-productividad-y-educacion/ 
Postigo, E. (2006). Diccionario de Bioetica. Obtenido de Academia.edu: https://www.academia.edu/2443555/Beneficencia_Principio_de

PRS Legislative Research. (2018). PRS Legislative Research. Obtenido de página oficial de la organización sin fines de lucro PRS: http://www.prsindia.org/

San Diego Fertility. (19 de Mayo de 2015). Sdfertiliry.com. Obtenido de Las agencias de maternidad subrogada y de donantes de óvulos: https://www.sdfertility.com/es/1 as-agencias-de-maternidad-subrogada-y-de-donantes-de-ovulos/

Santamaria Solis, L. (15 de Enero de 2000). Asociación Española de Bioética. Obtenido de Página Oficial Asociación Española de Bioética: http://aebioetica.org/revistas /2000/1/41/37.pdf

Sloan, K. (25 de Septiembre de 2017). Surrogacy Reaches the Supreme Court. Obtenido de Public Discourse. The Institute Witherspoon: http://www.thepublicdiscourse. com/2017/09/20130/

Team Management Ebooks. (02 de Julio de 2013). Porter's Five Forces. Obtenido de Free management ebooks: http://www.free-management-ebooks.com/dldebkpdf/fme-five-forces-framework.pdf

UAB, Fundacio Salut i Envelliment. (1990). Fundacio Doctor Robert UAB. Obtenido de Official Websait of Fundacio Doctor Robert: http://www.fdrobert.uab.es/docs/m onografies/1_Biotetica/06_C2_\%20El_Informe_Belmont.pdf

UCF Libraries. (02 de Febrero de 2018). University of Central Florida. Obtenido de University of Central Florida Libraries: http://guides.ucf.edu/industryanalysis/P ESTLE

UNESCO. (19 de Octubre de 2005). Declaracion Universal sobre Bioetica y Derecho Humanos. Obtenido de Página oficial de la UNESCO: http://portal.unesco.org/e s/ev.php- URL_ID=31058\&URL_DO=DO_TOPIC\&URL_SECTION=201.htm 


\section{BIBLIOGRAFÍA}

\subsection{Obras especializadas}

Ehrenrecih, N. (2005). The reproductive right readers. Nueva York: NYU Press editors

Warren Thomas, R. (1978). Encyclopedia of Bioethics. Michigan: Mc Millan Publ. C.O.

\subsection{Legislación \& Jurisprudencia Nacional}

F.D.N.R \& otros vs RENIEC, EXP.06374-2016-0-1801-JR-CI-05 (Quinto Juzgado Especializado en lo Constitucional Peruano, 21 de Febrero de 2017).

Ley que establece parámetros y garantías procesales para la consideración primordial del interés superior del niño, N 30466 (Diario Oficial el Peruano, Perú, 27 de Mayo de 2016).

\subsection{Legislación \& Jurisprudencia Extranjera}

Ley sobre Bioética, N 2004-800 (Diario oficial de la República francesa, Francia, 7 de Agosto de 2004).

Ley de protección del embrión, N 745-90 (Federal Law Gazette, Alemania, 13 de Diciembre de 1990).

Ley sobre técnicas de diagnostico prenatal, N 57-1994 (The Gazette of India, India, 20 de septiembre de 1994).

\subsection{Artículos de revistas impresas}

Heredia Cervantes, I. (2013). La dirección general de los registros del Notariado ante la gestación por sustitución. Revista ADC, 688-715.

Robles, B. (2011). La entrevista en profundidad: una técnica útil dentro del campo antropofísico. Scielo. 40-42

\subsection{Recursos electrónicos}

Agencia Estatal. (03 de Febrero de 2018). Ministerio de la Presidencia y para las Administraciones territoriales. Obtenido de https://www.boe.es/buscar/doc.php? id=BOE-A-1988-27108 
Choy, M., \& Chang, G. (01 Abril de 2014). Medidas macroprudenciales aplicadas en el Perú. Lima: Banco Central de Reserva del Perú. Obtenido de: http://www.bcrp.g ob.pe/docs/Publicaciones/Documentos-de-Trabajo/2014/documento-de-trabajo07-2014.pdf

Ministerio de Salud. (3 de Marzo de 2018). Obtenido de Página Oficial del Ministerio de Salud: http://www.minsa.gob.pe/renhice/documentos/normativa/Ley\%20268421997\%20-\%20Ley\%20General\%20de\%20Salud\%20Concordada.pdf

Ministerio de Sanidad, servicios sociales e Igualdad. (10 de Junio de 2013). Ministerio de Sanidad, servicios sociales e Igualdad Gobierno de Espana. Obtenido de Sitio web del Ministerio de Sanidad, servicios sociales e Igualdad Gobierno de Espana: https://www.msssi.gob.es/

National Archives. (13 de Febrero de 2018). Página oficial del Gobierno Británico legislation.gov.uk. Obtenido de http://www.legislation.gov.uk/ukpga/1985/49

Organización Panamericana de la Salud. (Enero de 2005). Buenas practicas clinicas: Documento de las Americas. Obtenido de Página Oficial de Organización Panamericana de la Salud: https://www.paho.org/hq/?lang=es

Panizo Robles, J. (19 de Diciembre de 2016). ¿Se abre la brecha? El tribunal supremo reconoce el derecho a las prestaciones por seguridad social en los casos de maternidad subrogada. Obtenido de Centro de Estudios Financieros:

https://www.laboral-social.com/sentencias-TS-25-octubre-2016-3818-2015-16noviembre-2016-3146-2014-maternidad-subrogada-vientresalquiler reconocimiento-prestaciones-seguridad-social.html 


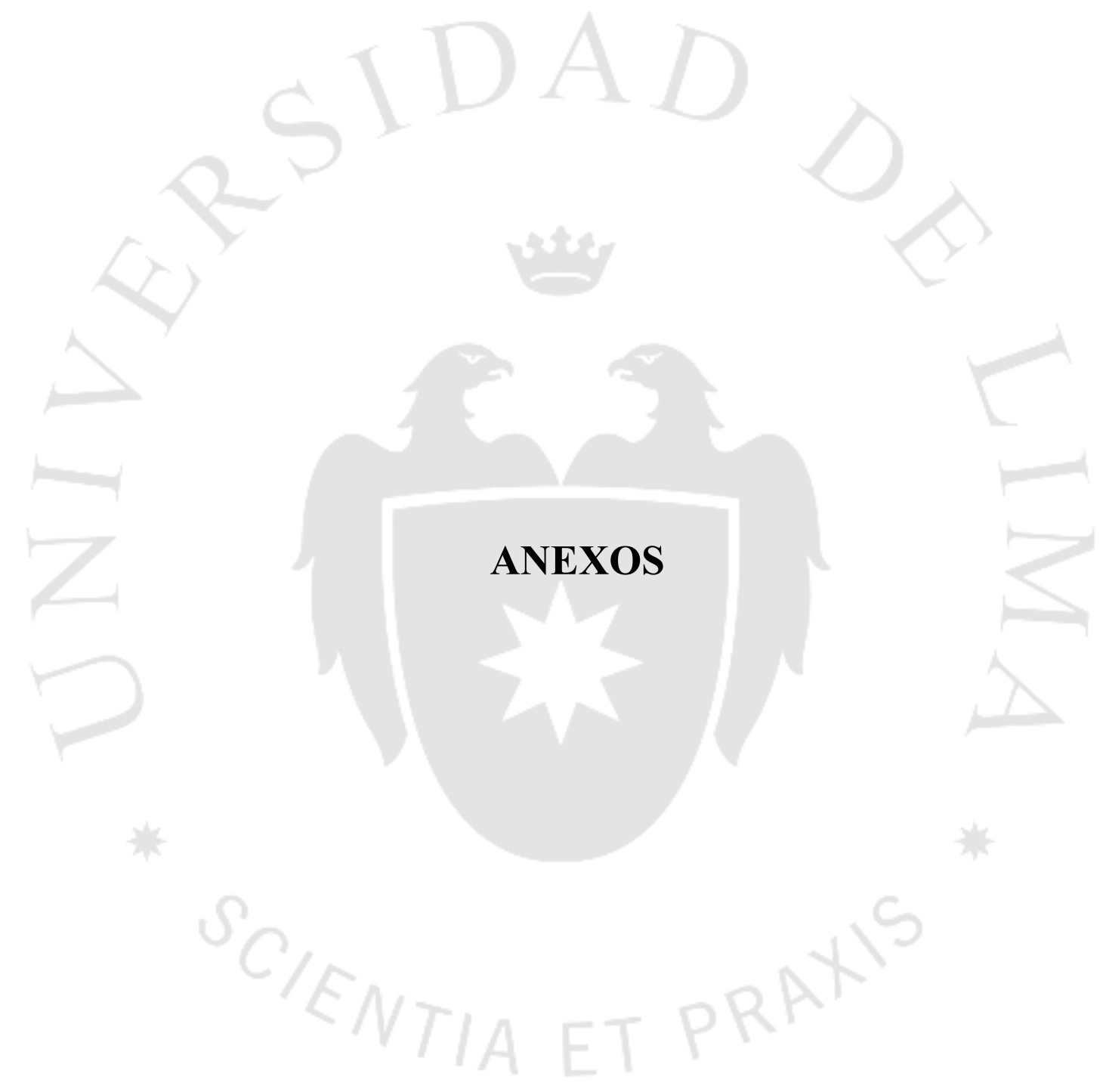


7.1 ANEXO 1: Análisis de regresión entre oportunidad económica de la mujer y precio de compensaciones de madres gestantes

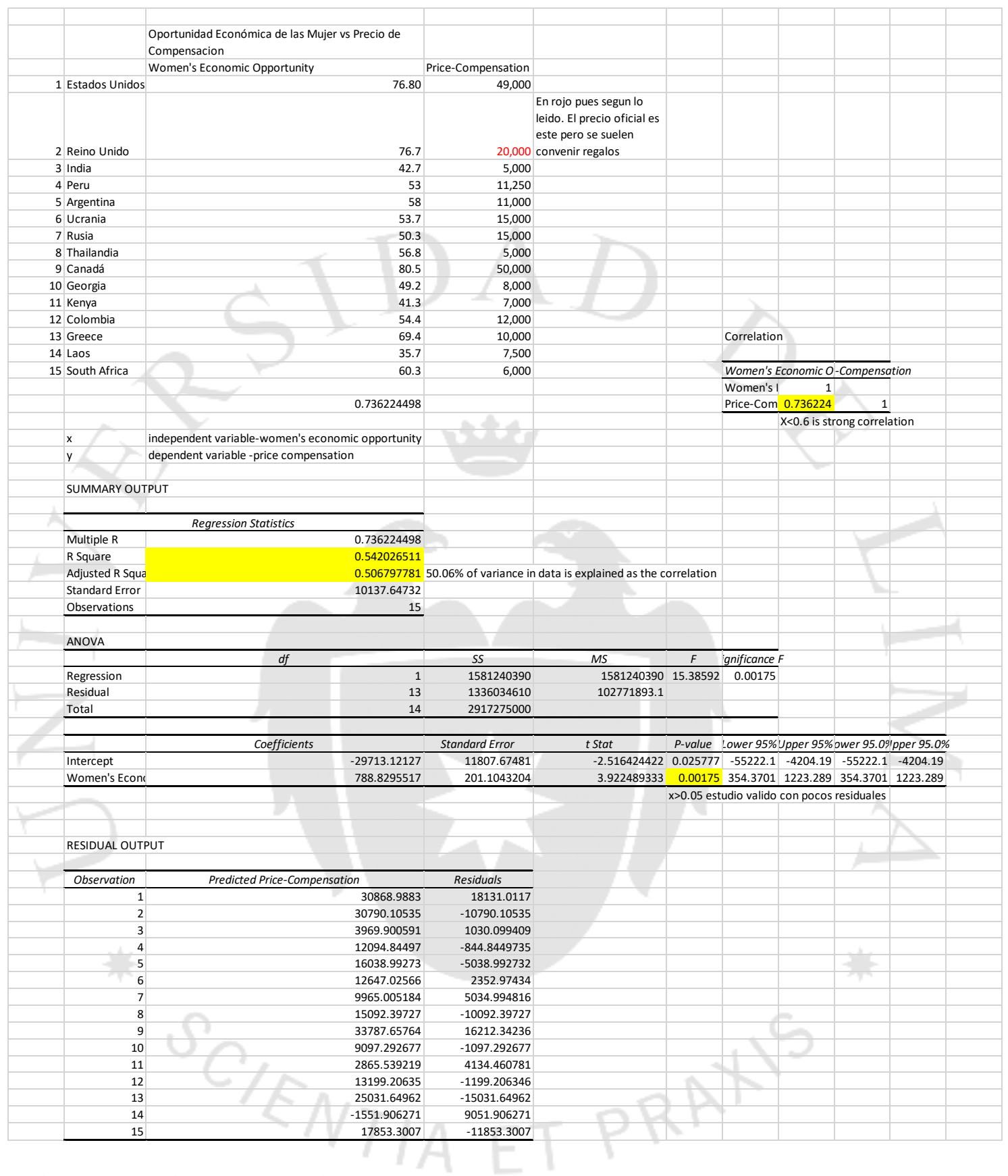

Precios de compensación en dólares americanos 
Mapa de tramas y tendencias

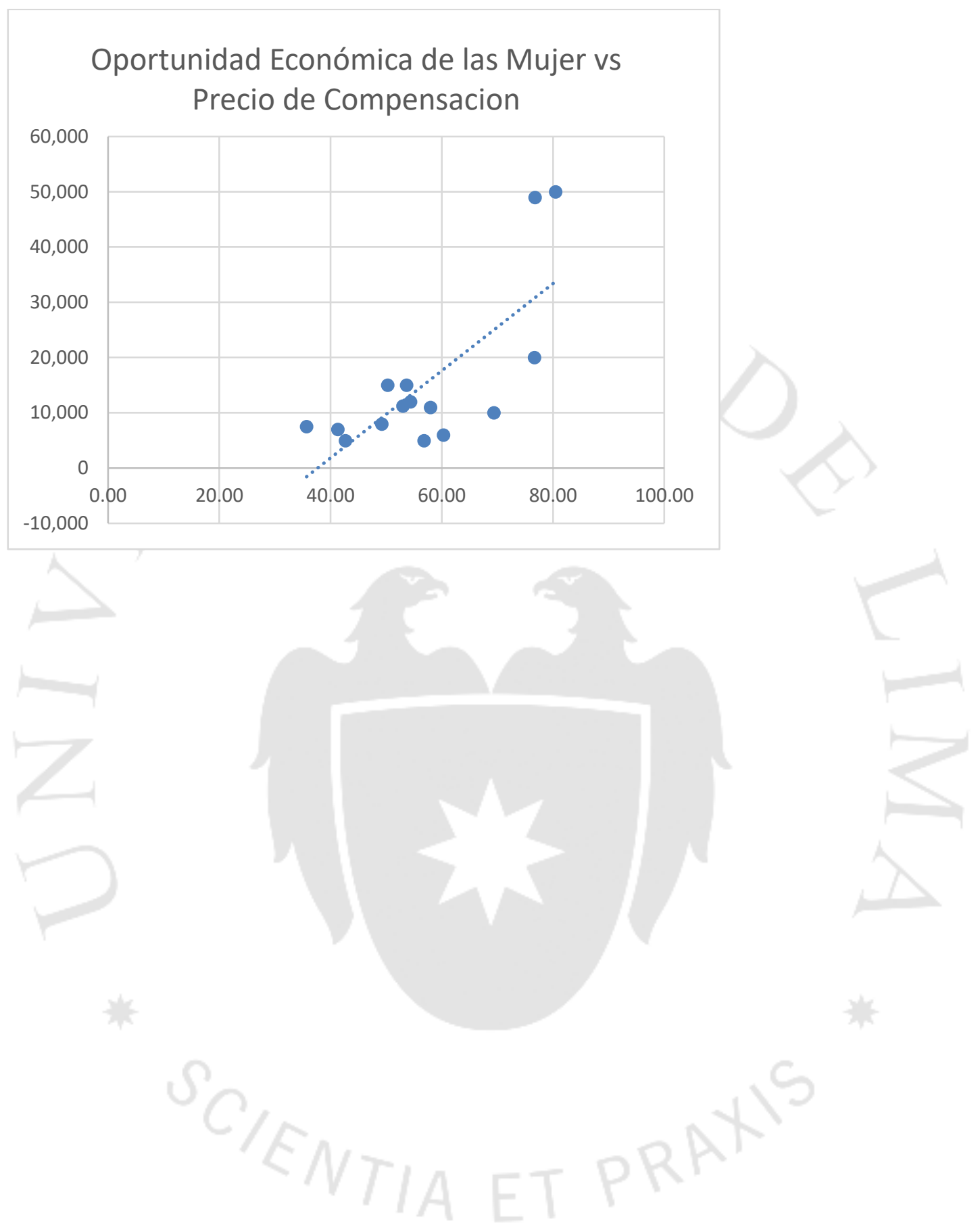

